\title{
Long Valley Caldera Lake and Reincision of Owens River Gorge
}

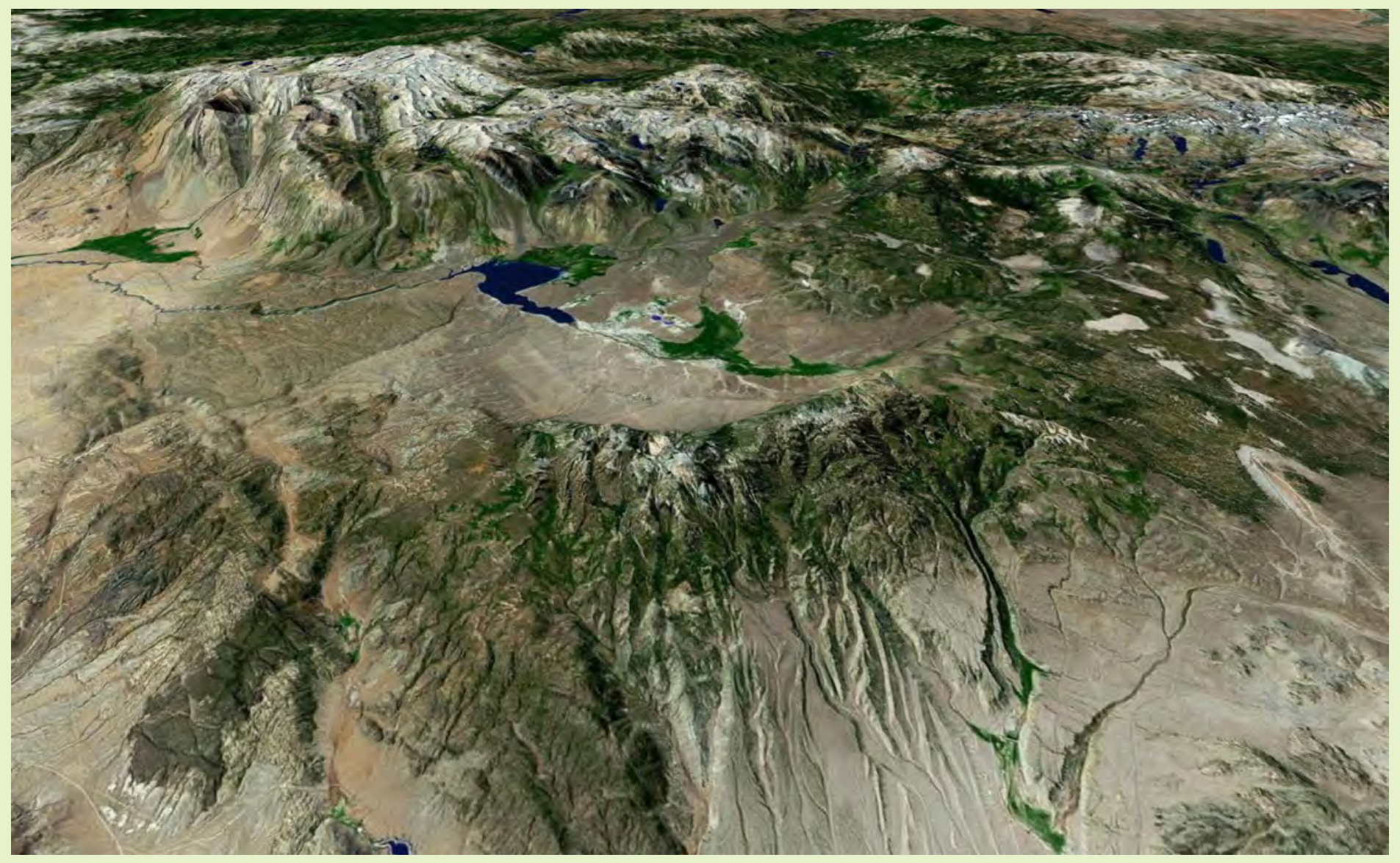

Scientific Investigations Report 2016-5120 
COVER

View southwestward across Long Valley Caldera and Sierra Nevada. Caldera depression, as wide as $30 \mathrm{~km}$, formed during eruption of Bishop Tuff at $767 \mathrm{ka}$. Sierra consists of Mesozoic plutonic rocks, Mesozoic metavolcanic rocks, and Paleozoic marine metasedimentary strata. Patchy white exposures in caldera are lacustrine siltstones of middle Pleistocene age that are the top of a 700-m-thick accumulation of intracaldera lake sediment. Sedimentation in the deep closed depression took 600,000 years to raise lake level to its threshold for overflow around $150 \mathrm{ka}$. Outlet arm of Lake Crowley reservoir leads into Owens River Gorge, which extends $30 \mathrm{~km}$ southeast across a welded Bishop Tuff outflow sheet. Overflow and draining of the caldera lake reincised a 200-m-deep precaldera gorge (in Mesozoic granodiorite) that had been diverted by 3.3-Ma basalt and later blanketed by the Bishop Tuff. Round Valley Fault is 2-km-high eastfacing scarp at left. At lower center of image, precaldera Glass Mountain rhyolite edifice was truncated by caldera collapse and draped by complexly incised apron of Bishop Tuff. Photo is a NaturalVue satellite image mosaic, which has been extracted from a global dataset of natural-color Landsat-7 multispectral images compiled by MDA Information Systems, Inc. Cover image produced and processed by Joel E. Robinson. Imagery copyright 2010, MDA Information Systems, USGS, NASA. 


\section{Long Valley Caldera Lake and Reincision of Owens River Gorge}

By Wes Hildreth and Judy Fierstein

Scientific Investigations Report 2016-5120 


\title{
U.S. Department of the Interior SALLY JEWELL, Secretary
}

\section{U.S. Geological Survey Suzette M. Kimball, Director}

\author{
U.S. Geological Survey, Reston, Virginia: 2016
}

For more information on the USGS - the Federal source for science about the Earth, its natural and living resources, natural hazards, and the environment-visit http://www.usgs.gov/ or call 1-888-ASK-USGS (1-888-275-8747).

For an overview of USGS information products, including maps, imagery, and publications, visit http://store.usgs.gov/

Any use of trade, firm, or product names is for descriptive purposes only and does not imply endorsement by the U.S. Government.

Although this information product, for the most part, is in the public domain, it also may contain copyrighted materials as noted in the text. Permission to reproduce copyrighted items must be secured from the copyright owner.

Suggested citation:

Hildreth, Wes, and Fierstein, Judy, 2016, Long Valley Caldera lake and reincision of Owens River Gorge: U.S. Geological Survey Scientific Investigations Report 2016-5120, 63 p., https://doi.org/10.3133/sir20165120. 


\section{Contents}

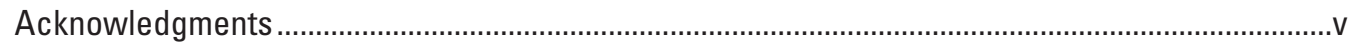

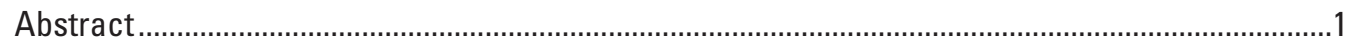

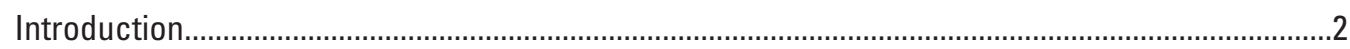

Neogene Origin of Owens River Gorge ...............................................................................

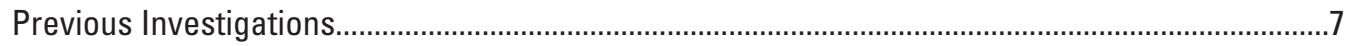

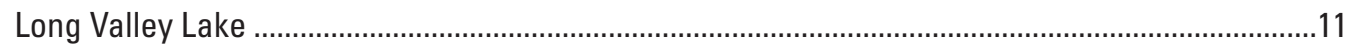

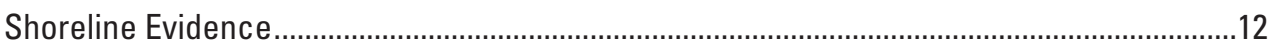

Elevations and Deformation of the Highstand ..............................................................15

Outlet Arm of the Pleistocene Lake ......................................................................................15

Unbreached Low Eastern Divide Enclosing Long Valley Basin ......................................17

Erratics along Deformed Shorelines .........................................................................................21

Sedimentary Deposits of Long Valley Lake ...............................................................................22

Drillholes into Lake Sediments and Paleoenvironmental Interpretations..............................23

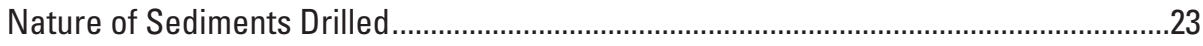

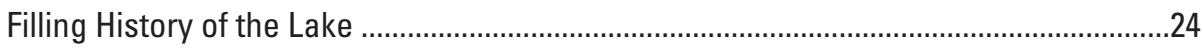

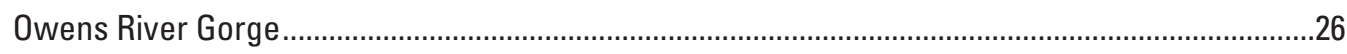

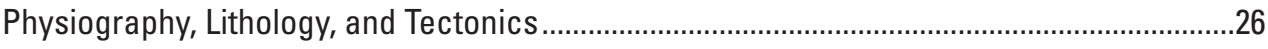

Gradients Along Owens River Gorge ...........................................................................26

Drainage Divide Incised by Owens River Gorge ...............................................................29

Southward Tilting of Volcanic Tableland............................................................................29

Sherwin Glacial Deposits in Owens River Gorge ......................................................................30

Alternative Post-Basalt Pre-Sherwin Course of Owens River ................................................33

Buried Channel North of Owens Gorge? ...............................................................................33

Buried Channel South of Owens Gorge? .............................................................................33

Buried Channel Diverted from Owens Gorge to Rock Creek Gorge.................................35

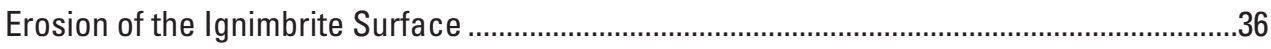

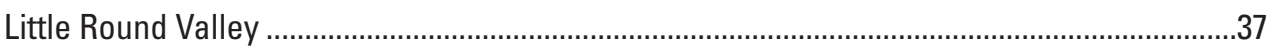

Headward Erosion of Owens River Gorge? .............................................................................38

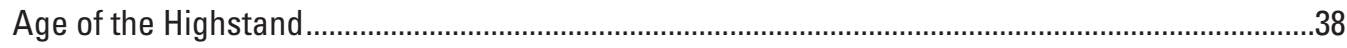

Lava Flows With and Without Shoreline Features ..................................................................40

Ages of Lacustrine Tufa ............................................................................................................... 41

Tephra Layers Intercalated with Lake Silt ..................................................................................41

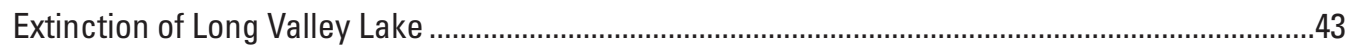

Processes Leading to Overflow ....................................................................................................49

Overflow and Draining of Long Valley Lake..........................................................................52

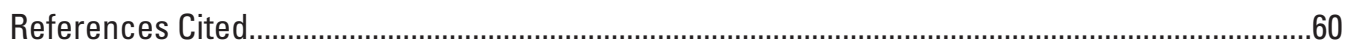




\section{Figures}

1. Regional location map for Long Valley Caldera and Owens River Gorge ...................................

2. Google Earth oblique image of Long Valley Caldera and Volcanic Tableland..............................

3. Location map for 30-km-long Owens River Gorge, everywhere rimmed by Bishop Tuff

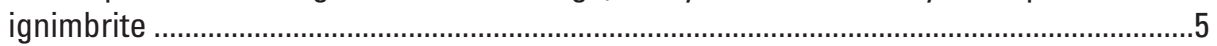

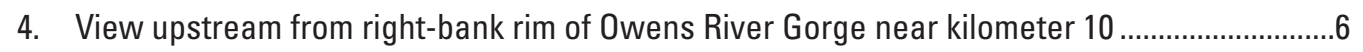

5. Map showing shoreline features and deposits of Pleistocene Long Valley Lake .......................

6. Profile along tunnel \#1, modified from Putnam .......................................................................10

7. Typical littoral deposits along highstand shoreline along east side of Pleistocene Long Valley Lake, north of Watterson Canyon ...............................................................................13

8. Set of shorelines at southeast margin of early rhyolite on resurgent uplift..............................14

9. Profile of eastern highstand shoreline of Pleistocene Long Valley Lake from Wilfred Canyon southward to Owens Gorge and Little Round Valley .......................................................16

10. Highstand shoreline along southeast margin of Pleistocene Long Valley Lake ......................17

11. Geologic map of upper Owens Gorge and Rock Creek Gorge .............................................19

12. Panorama, looking northwest, of Lake Crowley reservoir and intracaldera basin of Pleisto-

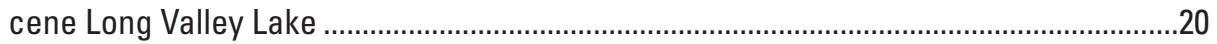

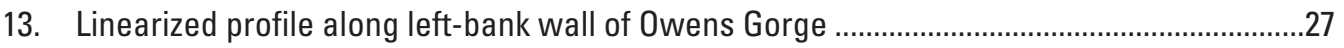

14. Middle reaches of Owens River Gorge, 150-200 m deep, viewed northward ........................28

15. Schematic cross sections of Owens Gorge and vicinity .....................................................

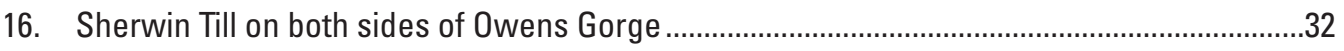

17. Owens River Gorge viewed southward from left-bank rim ...................................................34

18. Sherwin outwash exposed in gully midway up right-bank wall of Owens Gorge, $\sim 200 \mathrm{~m}$ west of power house \#1 ................................................................................................

19. Little Round Valley viewed southward from crest of knoll 2224 .............................................39

20. Locations of seven tephra sections measured in silt deposits of Pleistocene Long Valley Lake ................................................................................................................

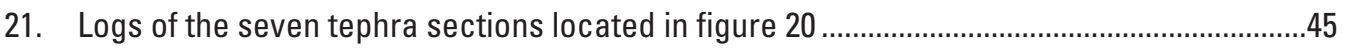

22. Ash layers intercalated in white silt near top of Pleistocene lacustrine exposure on knoll 2096.

23. Plots of electron-microprobe data for magnetite, ilmenite, and biotite phenocrysts from silicic tephra layers in lacustrine silt section exposed at Owens River bluff compared with same phases from Pleistocene silicic lavas in Long Valley Caldera

24. Chemical plots of electron-microprobe data for olivine phenocrysts in several mafic tephras intercalated in exposures of lacustrine silt.

25. Outlet arm of Lake Crowley reservoir where Long Valley Dam blocks entrance to Owens

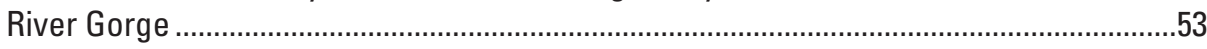

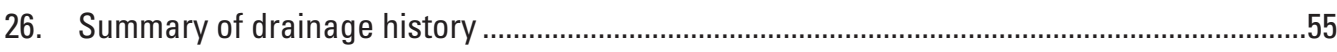

\section{Table}

1. U-Th isotopic data and ages for Long Valley tufas. 


\section{Appendixes}

[Available online at https://doi.org/10.3133/sir20165120]

1. Chemical Analyses of Pliocene Basaltic Shield at Owens River Gorge

2. Six Sets of Regressive Shorelines Lower than Highstand of Long Valley Lake

\section{Acknowledgments}

Marith Reheis and Ken Adams, authorities on Pleistocene lakes in the Great Basin, made many useful suggestions in the field and on the manuscript. Helpful reviews by Charlie Bacon and Paul Stone improved our presentation. Bob Drake and Paty Sruoga joined us in scrambles up and down the walls of Owens Gorge. Joe Liddicoat directed us to tephra layers near Benton Crossing in the lake-silt section he sampled for paleomagnetic studies. Warren Sharp made the U-series determinations on our tufa samples (table 1). Andy Calvert determined the ${ }^{40} \mathrm{Ar} /{ }^{39} \mathrm{Ar}$ ages cited here (table 2 of Hildreth and others, 2014). Joel Robinson provided vital GIS support, and Leslie Hayden facilitated and supervised our electron-probe analytical work. Kevin Denton coached us in use of the Trimble Geo XH and processed the field GPS data we acquired. Emily Montgomery-Brown retrieved and reduced regional geodetic data to estimate present-day uplift rates east of the caldera. Scott Starratt examined diatoms in exposed siltstones of Pleistocene Long Valley Lake. Sue Barak retrieved and reduced precipitation data for the upland area. Allen Glazner let us select oblique aerial photographs from his extensive regional collection. Years of discussion with Dave Hill have contributed to our ever-growing understanding of the tectonic history of the Long Valley region. Bob and Sally Drake of Old Mammoth provided years of hospitality and companionship during the long lifetime of this investigation. Hildreth has long been grateful to the late Clyde Wahrhaftig for imparting his fascination with the history of the landscape. And even lan Carmichael's familiar quip "water runs downhill," which epitomized his interest in surface processes, provided an unforeseen insight in cracking the puzzle of Owens River Gorge. Thanks to all. 



\title{
Long Valley Caldera Lake and Reincision of Owens River Gorge
}

\author{
By Wes Hildreth and Judy Fierstein
}

\section{Abstract}

Owens River Gorge, today rimmed exclusively in 767-ka Bishop Tuff, was first cut during the Neogene through a ridge of Triassic granodiorite to a depth as great as its present-day floor and was then filled to its rim by a small basaltic shield at $3.3 \mathrm{Ma}$. The gorge-filling basalt, $200 \mathrm{~m}$ thick, blocked a 5-km-long reach of the upper gorge, diverting the Owens River southward around the shield into Rock Creek where another 200-m-deep gorge was cut through the same basement ridge. Much later, during Marine Isotope Stage (MIS) 22 ( 900-866 ka), a piedmont glacier buried the diversion and deposited a thick sheet of Sherwin Till atop the basalt on both sides of the original gorge, showing that the basalt-filled reach had not, by then, been reexcavated. At $767 \mathrm{ka}$, eruption of the Bishop Tuff blanketed the landscape with welded ignimbrite, deeply covering the till, basalt, and granodiorite and completely filling all additional reaches of both Rock Creek canyon and Owens River Gorge. The ignimbrite rests directly on the basalt and till along the walls of Owens Gorge, but nowhere was it inset against either, showing that the basalt-blocked reach had still not been reexcavated. Subsidence of Long Valley Caldera at 767 ka produced a steep-walled depression at least $700 \mathrm{~m}$ deeper than the precaldera floor of Owens Gorge, which was beheaded at the caldera's southeast rim. Caldera collapse reoriented proximal drainages that had formerly joined east-flowing Owens River, abruptly reversing flow westward into the caldera. It took 600,000 years of sedimentation in the 26-km-long, usually shallow, caldera lake to fill the deep basin and raise lake level to its threshold for overflow. Not until then did reestablishment of Owens River Gorge begin, by incision of the gorge-filling ignimbrite.

Lake sediments in the caldera include a peripheral littoral facies, locally deltaic, that consists of pebbly sandstone and nonindurated shingle, which are dominated in different sectors by material eroded from precaldera rhyolites, postcaldera rhyolites, or basement rocks; and a central siltstone facies, which is rich in rhyolitic ash, diatoms, and ostracods. Cuttings from a deep well that penetrated the $700 \mathrm{~m}$ of tuffaceous sediment atop the intracaldera Bishop Tuff suggest fluctuation between slightly and moderately saline conditions during deposition of the lower $\sim 530 \mathrm{~m}$ and fresh (probably deeper) water for the upper $\sim 170 \mathrm{~m}$. Littoral deposits help define a highstand shoreline that surrounded a lake that once covered at least $330 \mathrm{~km}^{2}$. Highstand features are continuously preserved along the east side of the former lake, discontinuously along the north and west sides, and are concealed by post-lake alluvial fans on the northeast and southwest sides. Since regression of the lake, the eastern strandline has tectonically tilted $0.8-0.9^{\circ} \mathrm{S}$. (toward the Round Valley Fault), thus lowering the basin's outlet at Owens River Gorge by $185 \mathrm{~m}$ relative to highstand elevation at Glass Mountain $14 \mathrm{~km}$ north. Shoreline features along the west side have been raised and tilted slightly by secular uplift of the caldera's resurgent dome. A few patches of shoreline gravel on basement rocks along the caldera's north wall may thus be the only undeformed remnants of the highest strandline. Numerous clusters of metamorphic and granitoid boulders, evidently ice-rafted from Sierran sources, are scattered along the east side of the lake (well below the highstand), and many more were dropped on west-facing slopes of the early postcaldera rhyolite, where they were later lifted 100-250 m higher than nearby shoreline features by structural resurgence.

Lacustrine sandstone deposited on the 333-ka Hot Creek rhyolite coulee and U-series ages of $257 \pm 16 \mathrm{ka}$ for lacustrine tufa, $\sim 80 \mathrm{~m}$ lower than the highstand, show that the lake was still extensive late in the middle Pleistocene. Identification by Liddicoat and others (1998) of the Pringle Falls geomagnetic excursion and associated layers of Oregon-derived silicic ash within a siltstone section exposed in central Long Valley shows that the lake outlasted the $211 \pm 13$-ka excursion. Another siltstone section, stratigraphically higher, contains layers of hornblende-biotite rhyolite tephra, which (as shown by microprobe data) match the 150 -ka West Moat Coulee but not any of the many other postcaldera Long Valley rhyolites. Among several mafic lava flows along the caldera's south moat, only the oldest $(180 \pm 3 \mathrm{ka})$ had lacustrine sandstone deposited on it, whereas the others (172-92 ka) do not, indicating that the lake was shrinking by early in pluvial MIS 6 (191-130 ka), presumably owing to initiation of overflow and spillpoint lowering. A 100-ka basaltic lava flow on the floor of the caldera's north moat bears no evidence of lake interaction but extends to an elevation lower than the lake's outlet channel, suggesting that the lake had drained.

Siltation of the lake basin, downwarping of the outlet sill, $\sim 50 \mathrm{~m}$ of erosive lowering of the lake-facing ignimbrite surface, and intensification of Sierran runoff during MIS 6 contributed to eventual overflow. Capture of the lake by headward erosion upstream from Owens Valley is rejected on the basis of climate, lithology, other nearby drainage patterns, and the meandering course of Owens River Gorge itself. Prior to overflow, the lake developed a fjord-like inlet at least $5 \mathrm{~km}$ long that coincided with the subsequent outlet and along the rim of 
which highstand gravels and beachrock were deposited. The inlet coincided not only with the upper end of modern Owens Gorge but with the course of the ignimbrite-filled proximal reach of the Neogene gorge that had extended to the basaltic blockage.

A north-trending divide on the ignimbite surface crosses Owens River Gorge perpendicularly and separates tableland slopes toward Long Valley and Owens Valley. The ignimbrite divide at the gorge rim is today $80 \mathrm{~m}$ higher than the highstand gravels at the outlet arm, $4 \mathrm{~km}$ west. We infer that a compactional swale where the ignimbrite had filled the Neogene gorge concentrated seasonal runoff from the divide toward Long Valley Lake, promoting reverse (eastward) headward erosion, gradually reincising the Neogene drainage through the Bishop Tuff, and eventually impinging eastward on the 3.3-Ma basaltic blockage beneath the ignimbrite. Erosion of the rubbly basalt would then have accelerated overflow, and little or no incision of the granodiorite would have been required as the gorge reestablished itself through the gorge-filling basalt. Downstream from the former basalt blockage, throughgoing drainage from Long Valley would then have meandered consequently across the Volcanic Tableland ignimbrite surface and later incised antecedently as tectonic tilt progressively steepened its slope toward Owens Valley.

\section{Introduction}

After collapse of Long Valley Caldera (figs. 1,2) during pyroclastic eruption of the Bishop Tuff at $767 \mathrm{ka}$, a long-lived lake collected in the depression and persisted throughout much (but not all) of the middle Pleistocene. Much of the western half of the caldera floor was soon covered by thick and voluminous lavas and tuffs of what Bailey and others (1976) called the early rhyolite ( 750-640 ka), most of which were faulted and uplifted resurgently, thereafter confining the lake to the eastern half of the caldera floor. Just southeast of the caldera, Owens River Gorge was eroded through the Volcanic Tableland, a south-sloping ignimbrite plateau that is a principal sector of the Bishop Tuff outflow sheet. It has been widely assumed that cutting of Owens Gorge drained the intracaldera lake, either by overflow or by headward erosion. But neither the timing nor process of extinction of the lake nor the complex history of gorge excavation has been adequately established. In the present investigation, we mapped in detail the caldera and gorge at a scale of 1:24,000, reexamined previous interpretations, and developed several new data sets that bear upon both lake and gorge. As college classes and professional field excursions have highlighted this region for decades, the Owens River Gorge has become as iconic as the Bishop Tuff.

\section{Neogene Origin of Owens River Gorge}

The Owens River Gorge drains Long Valley caldera and cuts southeast through the Bishop Tuff outflow sheet for $\sim 30 \mathrm{~km}$, descending $\sim 730 \mathrm{~m}$ before emerging onto the lowrelief Owens Valley floodplain $\sim 8 \mathrm{~km}$ northwest of Bishop (figs. 1-3). Generally deeper than $100 \mathrm{~m}$ proximally and distally, gorge depth reaches 200-260 m along a 7-km-long middle reach where it cuts through the Bishop Tuff into older rocks. These include the Triassic Wheeler Crest Granodiorite (Bateman, 1992) and Pliocene basalt (Rinehart and Ross, 1957; Dalrymple, 1963), as well as Sherwin Till (Blackwelder, 1931; inferred to represent Marine Isotope Stage 22 [900-866 ka] and (or) 20 [814-790 ka]; Lisiecki and Raymo, 2005), which is locally sandwiched between the 3.3-Ma basalt and the Bishop Tuff (Putnam, 1960).

The Bishop Tuff, the caldera-forming rhyolitic ignimbrite (767 ka), forms the entire surface (the Volcanic Tableland) through which the gorge is incised. The ignimbrite ranges from nonwelded to densely welded (Wilson and Hildreth, 1997, 2003) and is as thick as $230 \mathrm{~m}$ near the upstream end of the granodiorite window and 180-210 $\mathrm{m}$ at its downstream end where the granodiorite drops below the level of the gorge floor. Where it overlies the 7-km-long window, however, the ignimbrite thins to $35-75 \mathrm{~m}$, showing that the granodiorite had formed a north-trending paleoridge over which the ignimbrite draped and through which the Owens Gorge had much earlier been cut. Roughly parallel to Owens Gorge and a few kilometers west, Rock Creek gorge forms a 220-m-deep trench through the same granodiorite ridge (fig. 3), as well as incises thick adjacent sections of Sherwin Till and Bishop Tuff.

Because most of the Owens Gorge is walled only by Bishop Tuff, few have appreciated that the gorge dates from the Miocene. The Owens River had crossed the later site of the caldera from sources farther north and had cut the deep granodiorite gorge before eruption of the 3.3-Ma basalt. Gorge walls made of granodiorite alone are commonly 100-150 m high and locally as high as $240 \mathrm{~m}$. Near the basalt vent (scoriaceous knoll 2190), 250 m east of the gorge rim (fig. 3), dozens of lava flows poured into the granodiorite gorge, completely filling it with a stack of basalt as thick as $200 \mathrm{~m}$. Still today, after reincision, the east wall of the gorge just west of the basalt vent consists of $190 \mathrm{~m}$ of basalt flows (fig. 4), capped, in turn, by $60-90 \mathrm{~m}$ of Bishop Tuff. From this location, which is the thickest basalt exposure preserved, basaltic lavas, scoria, and agglutinate extend discontinuously along both walls for $2.2 \mathrm{~km}$ upstream and $3 \mathrm{~km}$ downstream, variously banked against the lower granodiorite wall or draping its higher slopes at $10^{\circ}-25^{\circ}$.

In several places, the basaltic pile extends all the way to the present-day riverbank at the gorge floor, showing that the pre-basalt granodiorite gorge had there been 190-240 m deep.

The many basalt outcrops each consist of 5-30 lava flows. Most flows form ledges $1-5 \mathrm{~m}$ high, separated by scoriaceous 


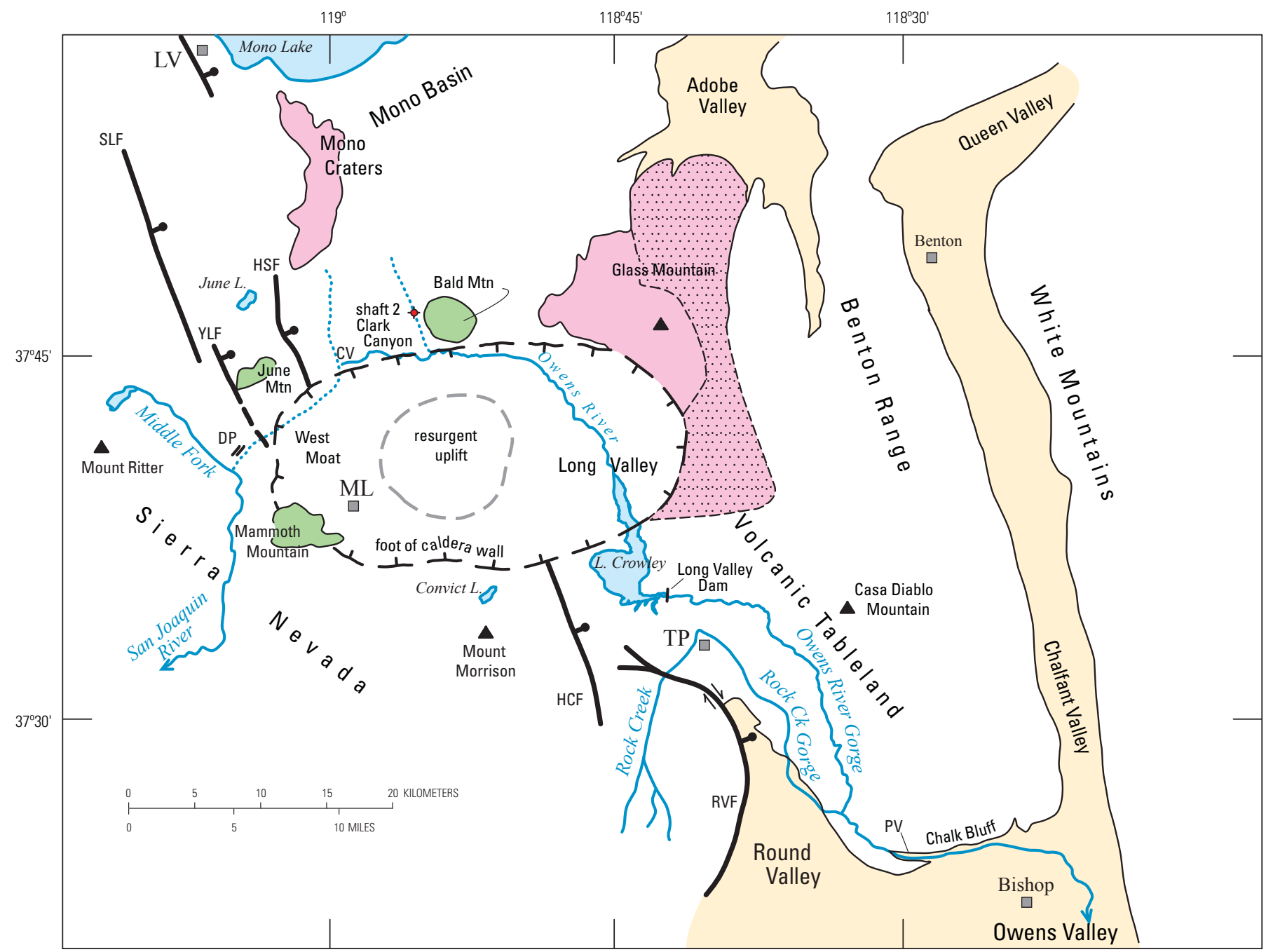

Figure 1. Regional location map for Long Valley Caldera and Owens River Gorge. Eruption of $\sim 650 \mathrm{~km}^{3}$ of rhyolite magma as the Bishop Tuff at $767 \mathrm{ka}$ was accompanied by 2-3 km of caldera subsidence. Growth of a caldera lake began immediately, but resurgent structural uplift of intracaldera Bishop Tuff and early postcaldera ( 750-640 ka) rhyolite tuffs and lavas reduced the lake to the eastern half of the depression (Long Valley proper). Lacustrine deposition of $\sim 700 \mathrm{~m}$ of ash-rich sediment took more than 600,000 years to raise the persistently shallow lake to its threshold for overflow. Ultimate overflow cut 30-km-long Owens River Gorge through the Bishop Tuff ignimbrite outflow sheet on the Volcanic Tableland. Dotted lines indicate two ancestral streams of Pliocene age: paleo-Owens River buried by Bishop Tuff north of Clark Canyon; and a paleo-tributary of the Middle Fork San Joaquin River, blocked by a stack of Pliocene basalts prior to rangefront faulting. Precaldera gravels of paleo-Owens River were intersected at Clark Canyon in shaft 2 of Mono Craters tunnel (Jacques, 1940). Lake Crowley is a reservoir impounded by Long Valley Dam since 1941, not a remnant of the caldera lake. Precaldera Glass Mountain rhyolite dome complex is adjoined by its own pyroclastic fan (stippled), which contributed voluminous sediment to the Pleistocene lake. Abbreviations: CV, Crestview; DP, Deadman Pass; HCF, Hilton Creek Fault; HSF, Hartley Springs Fault; LV, town of Lee Vining; ML, town of Mammoth Lakes; PV, Pleasant Valley; RVF, Round Valley Fault; SLF, Silver Lake Fault; TP, Toms Place; YLF, Yost Lake Fault. 


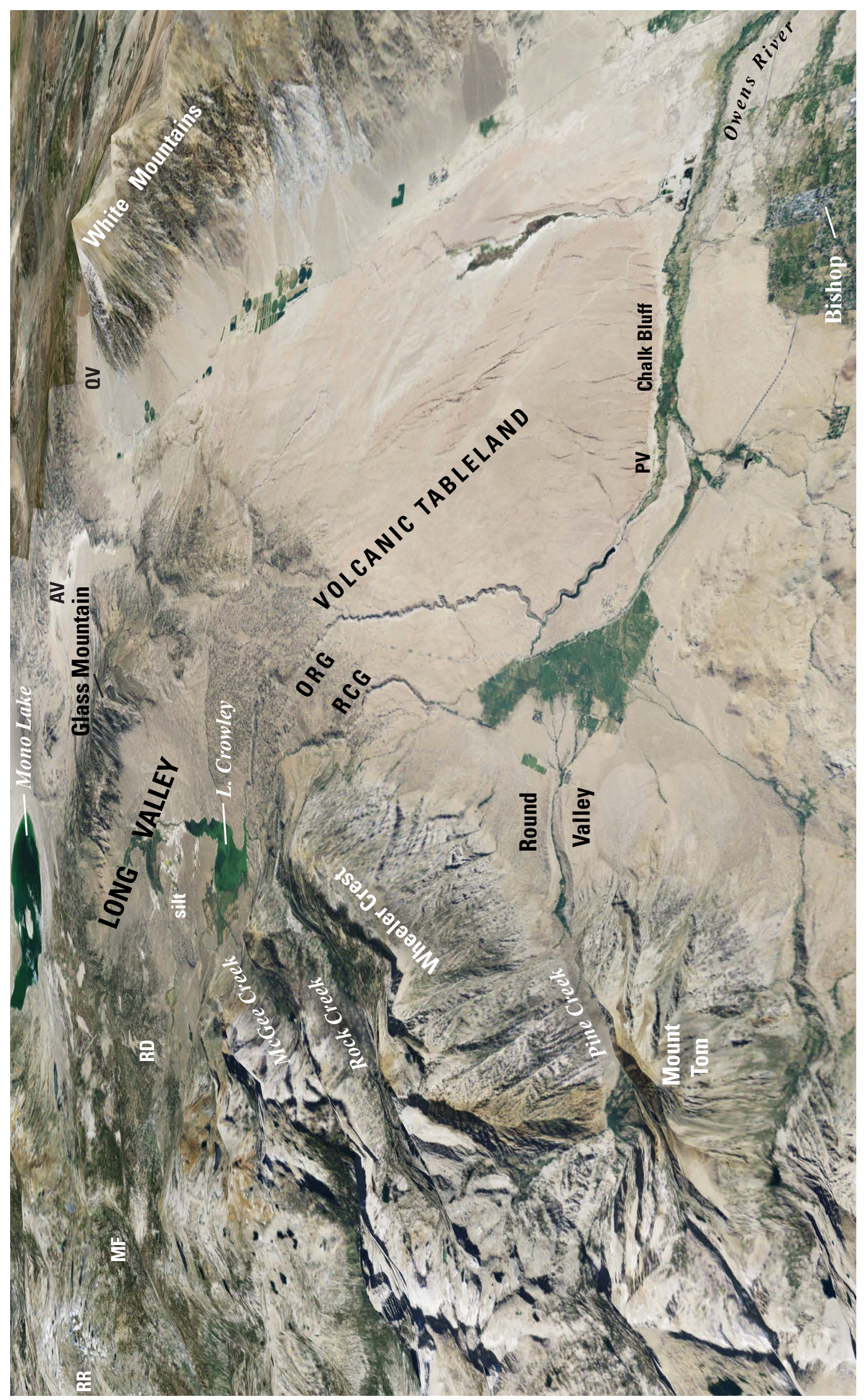

을

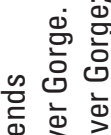

这离离

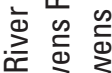

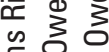

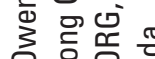

ํ.

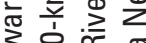

梁高

을 帝的

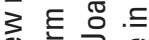

$>\sqrt{2}$

$\therefore$ 屯ॉ

๒

宁舟要

这语

岳

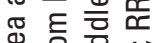

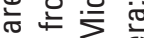

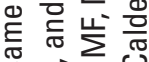

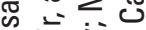

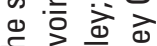

要要

@

है 흥ㅁㅁ듬

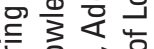

这交先

o is

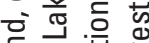

흔.

흥 흥.

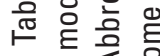

.눙

密㤩藃

응 क

흘

б

준 뭉

음

정 ๑

힝 잉

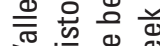

宊

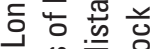

4 .

응음 헌

뜸 든

就 㐫

흠.

응응

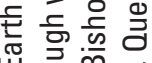

峁 닣

형흔 항

$0 \stackrel{0}{3}$

ง

言吾竞离 


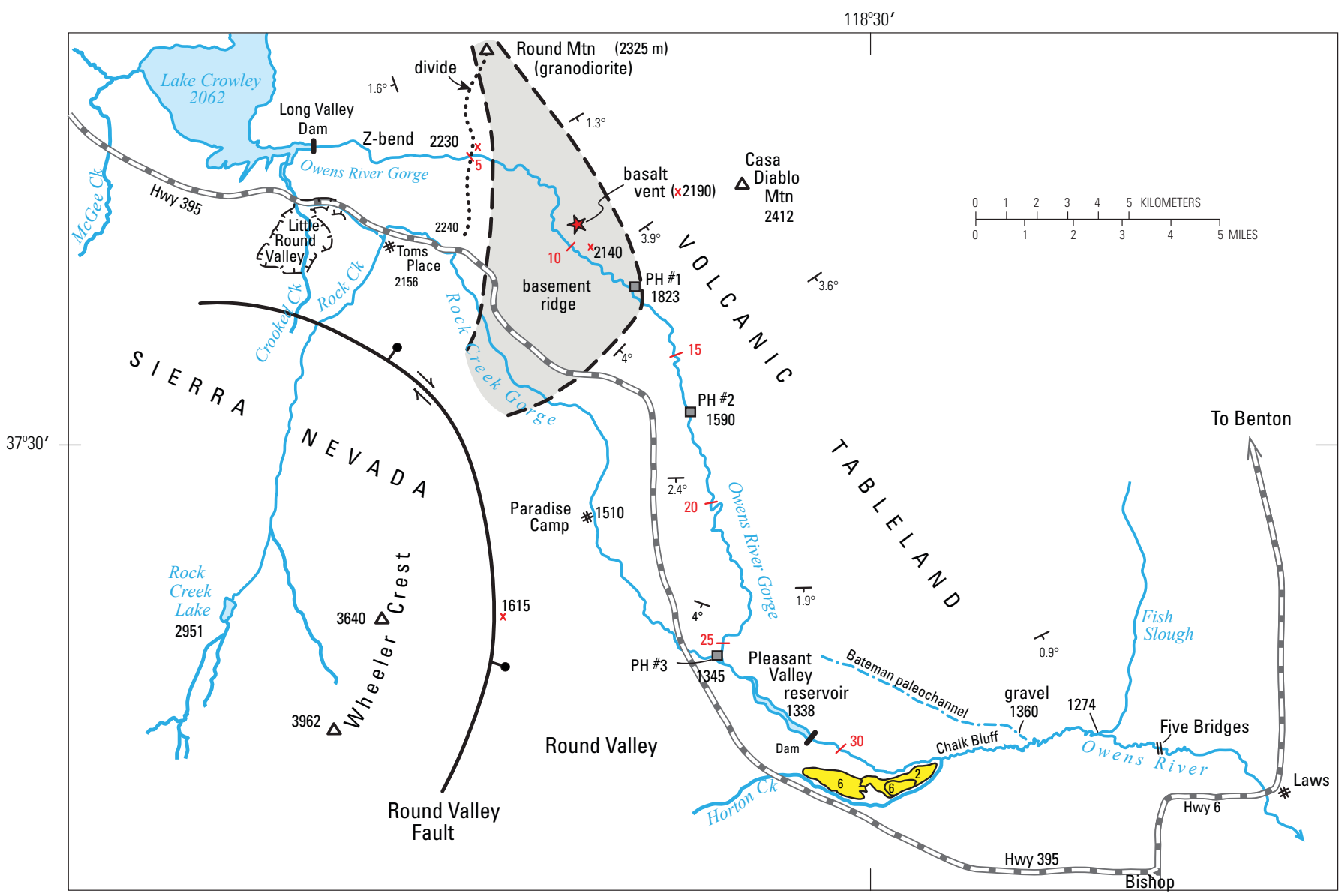

Figure 3. Location map for 30-km-long Owens River Gorge, everywhere rimmed by Bishop Tuff ignimbrite, which covers entire surface of Volcanic Tableland from Lake Crowley to Chalk Bluff. River kilometers downstream from Long Valley Dam are indicated in red in 5-km increments. Average slopes $\left(0.9^{\circ}-4^{\circ}\right)$ of warped Bishop Tuff surface are shown for several expanses where least irregularities permit generalization. Elevations, in meters above sea level, are given for key locations. On north side of Owens Gorge, x2230 marks high point on present-day ignimbrite rim of gorge, and x2140 marks highest point on granodiorite-basalt basement ridge buried by the ignimbrite. Dotted line through $\times 2230$ is subdued north-south drainage divide on ignimbrite surface, separating Long Valley and Volcanic Tableland. Shaded strip between dashed lines represents partly buried basement ridge, which is exposed in windows through the ignimbrite at Rock Creek Gorge, Owens Gorge, and Round Mountain. Stream terraces labeled 6 and 2 at south end of Owens Gorge are incised by modern channel and consist of coarse gravels thought to have been deposited during Marine Isotope Stages 6 and 2 (Tahoe and Tioga glaciations in Sierra Nevada). Terrace 2 and eastern remnant of terrace 6 contain cobbles of granodiorite and basalt from buried basement ridge reincised by Owens River upstream, but western remnant of terrace 6 and other terraces (not shown) south of Horton Creek lack basalt because they were deposited by Horton Creek, not by Owens River. Well-rounded stream cobbles along lower reach of shallow paleo-channel mapped by Bateman (1965) near Chalk Bluff include grussy granitoids, metasedimentary rocks, and Bishop Tuff, but not basalt. On Sierran rangefront, Round Valley Fault, both normal and dextral, exposes $\sim 2 \mathrm{~km}$ of relief on Mesozoic granitoids of Wheeler Crest. PH, power house. 

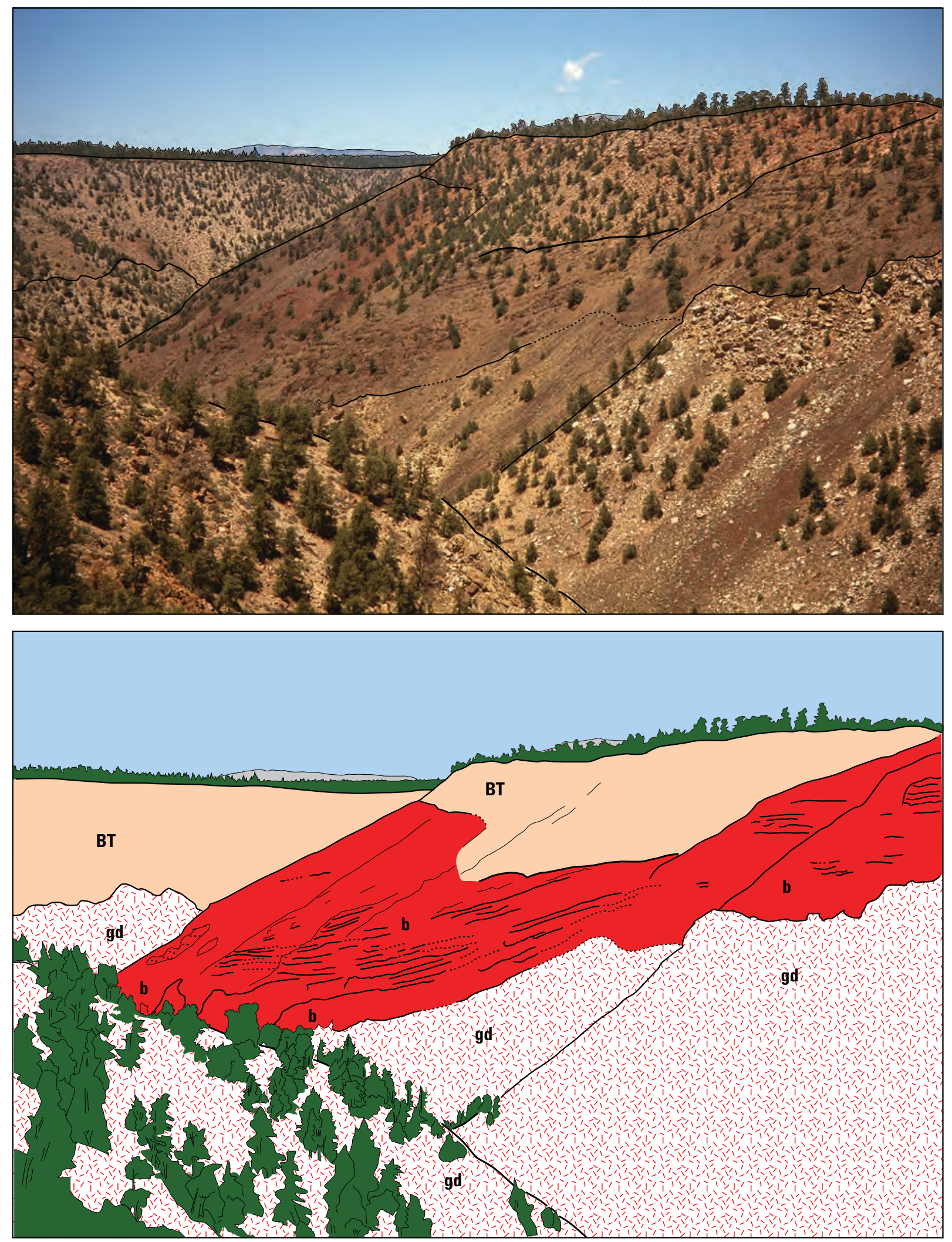

Figure 4. View upstream from right-bank rim of Owens River Gorge near kilometer 10 (see fig. 3). Gorge depth here is $\sim 250 \mathrm{~m}$. On opposite (left-bank) side, granodiorite wall in right foreground is $180 \mathrm{~m}$ high and is draped by stack of 15 basaltic lava flows that dip $\sim 20^{\circ}$ WSW., all the way to gorge floor. Canyon-filling basalt is as thick as $190 \mathrm{~m}$ at left center and overlain by 60-100 m of Bishop Tuff, which extends to rim on both sides. Basalt (b) and Bishop Tuff (BT) thin markedly to right where they drape over the granodiorite (gd) high, but both thicken again farther downstream. 
or rubbly interlayers, although a few of the earliest flows are 15-30 $\mathrm{m}$ thick. The flows analyzed ( $\mathrm{n}=13$; appendix 1$)$ form a continuous array of potassic trachybasalt and basaltic trachyandesite (51.2-53.7 percent $\mathrm{SiO}_{2}$ ) that contains 5.8-7.2 percent $\mathrm{MgO}, 98-144$ ppm Ni, 3.7-4.4 percent $\mathrm{K}_{2} \mathrm{O}, 1,900-2,600$ ppm $\mathrm{Ba}$, and $8-10$ percent olivine phenocrysts. They represent a comagmatic package of lava flows and ejecta from a common vent. Nowhere has an erosional unconformity been observed within the well-exposed basaltic package.

Because the basalt erupted at $3.3 \pm 0.1 \mathrm{Ma}$ (recalculated from Dalrymple, 1963), the steep-walled gorge it filled had been cut through the granodiorite still earlier by a paleo-Owens River vigorous enough to incise such a canyon. Although Pliocene topography upstream from Owens Gorge was obliterated by collapse of Long Valley Caldera at $767 \mathrm{ka}$, regional physiography admits no alternative to a precaldera course of the Owens River through the later site of the caldera, probably gathering tributaries from the Sierra Nevada on the west and from the later site of Mono Basin on the north. The largest reentrant cut into basement rocks on the north wall of Long Valley Caldera is today occupied by Clark and Alpers Canyons (figs. 1, 5), which are largely filled by Bishop Tuff. Beneath the Bishop Tuff are exposures of extensive fluvial gravels and a valleyconfined welded rhyolitic ignimbrite dated at $11.7 \pm 0.1 \mathrm{Ma}$ and derived from north of the caldera (Huber, 1981; Bailey, 1989; Hildreth and Fierstein, 2016). Moreover, at the head of Clark Canyon drilling identified stream gravels that extend to at least $108 \mathrm{~m}$ deeper than the base of the Bishop Tuff. Thick sands and gravels were encountered there in "shaft 2" (figs. 1, 5) and in associated headings during the 1934-1939 driving of the Mono Craters tunnel, within which stream sediments underlie and are intercalated with Pliocene basalts (Jacques, 1940; Gresswell, 1940). The pre-Bishop Tuff extracaldera gravels are now known to extend from present-day exposures as high as 2,280 $\mathrm{m}$ to drilled depths as low as $2,130 \mathrm{~m}$ above sea level (asl). The modern alluvial floor of the caldera's north margin at the mouth of Clark Canyon lies at 2,145-2,160 m asl, similar in elevation to the present-day rim of Owens River Gorge at its upstream entrance, which is outside the caldera and $25 \mathrm{~km}$ southeast of Clark Canyon.

We infer the Clark Canyon paleochannel to mark the principal course of the late Miocene to early Pliocene Owens River, which thence flowed $25 \mathrm{~km}$ southeastward across what is now the eastern part of the caldera into the granodioritewalled proto-Owens Gorge. The gorge was subsequently filled by basalt in the Pliocene and by Bishop Tuff in the middle Pleistocene. Drainage area and discharge of the Owens River were enhanced in the middle Pliocene by blockage of a Neogene tributary of the Middle Fork San Joaquin River that had also headed in the region that later became Mono Basin (fig. 1) and had flowed southwestward until its channel, across what is now the San Joaquin Ridge, was filled by a stack of 3.7-3.3-Ma basalts (Huber, 1981; Hildreth and others, 2014).

Middle and late Pleistocene incision of present-day Owens Gorge through the Bishop Tuff thus represented a new generation of canyon cutting, long after Miocene incision of the granodiorite gorge and Pliocene eruption of the canyon-filling basalt. Enduring questions that have challenged generations of geologists concern exactly when, why, and how Owens River Gorge was reincised through the Bishop Tuff and underlying basalt.

\section{Previous Investigations}

Mayo (1934) first noted that Long Valley had hosted a large Pleistocene lake, as recorded by extensive siltstone and sandstone deposits and several wave-cut strandlines; he attributed extinction of the lake to headward capture by Owens Gorge. Charles Merwin Gilbert (1938) named the Bishop Tuff, discussed its features along Owens Gorge, was first to describe it as an ignimbrite, was first to note that Sherwin glacial deposits underlie the Bishop Tuff, and collected the sample of Owens Gorge basalt dated by Dalrymple (1963). The upstream half of the gorge was mapped geologically by Rinehart and Ross (1957) and the downstream half by Bateman (1965), both at a scale of 1:62,500.

Rinehart and Ross (1957) recognized that the Bishop Tuff surface that forms the extensive Volcanic Tableland (figs. 1-3) had been downwarped toward Owens Valley, and they were first to note that shoreline gravels of Pleistocene Long Valley Lake had been tilted southward toward the lake's outlet into Owens Gorge. They attributed cutting of the gorge to spillover of the lake.

A deliberative monograph by Putnam (1960) is accompanied by a 1:24,000-scale geologic map of a 14-by-17-km area surrounding the upper halves of Rock Creek and Owens gorges. He remarked on the rough craggy surface of the Bishop Tuff on the upper half of the Volcanic Tableland, its maze of dry closed arroyos, and lack of integrated surface drainage. Putnam mapped Sherwin glacial deposits that underlie the Bishop Tuff on both walls of Owens Gorge, as had Rinehart and Ross (1957) more accurately. Putnam mapped lake-terrace gravels on waveplaned surfaces of the Bishop Tuff on both sides of the lake's outlet arm (figs. 1, 3, 5) where Pleistocene Long Valley Lake had extended as a narrow inlet into what later became the upper entrance to Owens Gorge. He and Mayo (1934) speculated that the lake's highstand could have taken place during the Tahoe glacial stage (now considered Marine Isotope Stage [MIS] 6), but Putnam acknowledged that there was no real evidence for such timing, in particular because nowhere do paleo-shorelines extend high enough to touch Tahoe moraines. Putnam recognized that all or part of Rock Creek had once drained northwest from Toms Place via Little Round Valley and Crooked Creek (fig. 3) into Long Valley's outlet arm, and he observed that Long Valley Lake, at its highstand, had extended shallowly southward into Little Round Valley.

During its construction, Putnam (1960) mapped the 11.3-km-long tunnel driven in 1949-1951 by the Los Angeles Department of Water and Power (LADWP; Mason, 1949; Morris, 1955) to link Lake Crowley reservoir at Long Valley Dam 


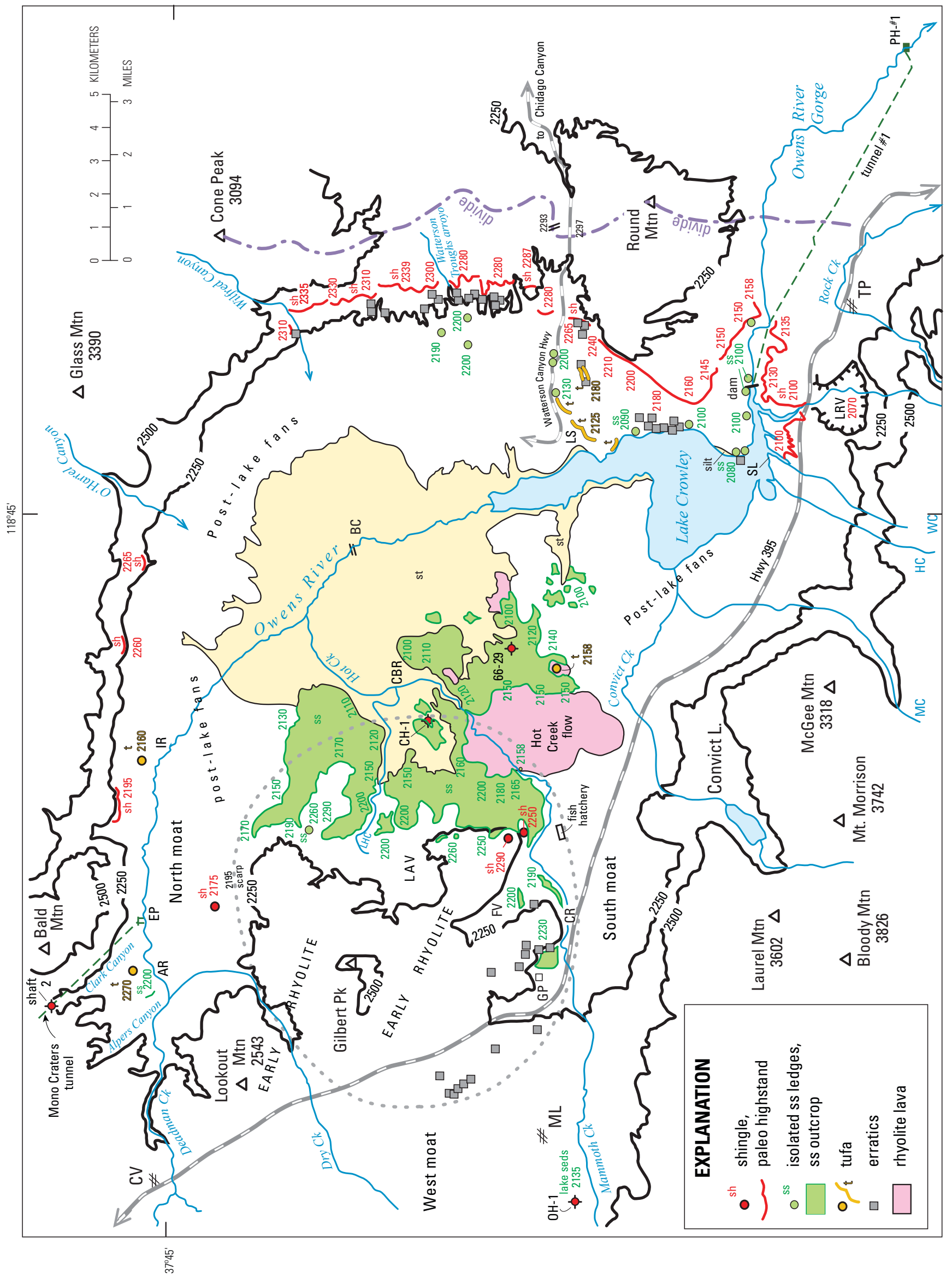


to a steep penstock above power house \#1 (fig. 5). Putnam's inspection of the tunnel (10 feet in finished diameter; running 0.5-2 km south of upper Owens Gorge) and of cores and logs from five test holes drilled along the tunnel alignment provided key data about subsurface thickness and distribution of the basalt, till, and ignimbrite that overlie the granodiorite basement (fig. 6).

Putnam's valuable study (1960) is weakened, however, by his failure to appreciate that Long Valley is a caldera and that the caldera lake took a very long time to fill the exceptionally deep caldera depression (with sediment far more than water) to its threshold for overflow. Neither Putnam nor others seem to have appreciated the significance of the fact that ancestral Owens Gorge had been cut deeply through the granodiorite, essentially along its present course, before being completely filled by Pliocene basalt. Putnam had further assumed that the granodiorite paleoridge (rather than the caldera) had impounded Long Valley Lake, and he showed little appreciation for the mobility of the multi-package rhyolitic ignimbrite that surmounted, thinned, and draped over the ridge, thickening to the southeast beyond it. In his 1960 monograph, Putnam argued the case for capture and draining of the lake by headward erosion of Owens River, but he added a paragraph acknowledging antecedence as a reasonable alternative (p. 247). He had previously written that Owens Gorge "was excavated in part by overflow of Long Valley Lake" (Putnam, 1952), and he cited unpublished arguments by F.E. Matthes in favor of overflow rather than headward erosion (Putnam, 1960, p. 248).

Wahrhaftig (1965, p. 100) rejected the headward erosion model, citing antecedent and abandoned shallow channels of the Owens River on distal parts of the Volcanic Tableland and the abundance along the modern gorge of deeply incised meanders, which he inferred to indicate antecedence across a lower-relief surface. He also reasoned that the meanders have wavelengths and amplitudes consistent with a vigorous Owens River, not with a minor creek eroding headward. Wahrhaftig also pointed out that the paleo-lake's outlet arm (at the origin of Owens Gorge) is the low point on the rim of the Long Valley hydrographic basin and that the few streams with discharge adequate to have cut canyons through the Bishop Tuff all have highland sources outside the dry, permeable, elsewhere weakly incised surface of the ignimbrite itself.

Bailey and others (1976) recorded (1) lakeshore gravels on the caldera's east wall as high as 2,320 m, (2) erratics from Sierran sources (inferred to be iceberg-rafted) along both the eastern lakeshore and raised high on the caldera's resurgent uplift, and (3) local patches of tufa (generally lower than the highest shoreline). They agreed that the outlet had been downwarped, but they provided no evidence for an assertion that the lake had once reached an elevation of 2,380 m. Citing a nonhydrated early rhyolite lava flow (their site 14) atop a perlitized flow on the resurgent uplift, they interpreted the latter to have entered the lake and the 2,320-m contact to approximate the lake level at $\sim 634 \mathrm{ka}$ (recalculated as $\sim 652 \mathrm{ka}$ by Mankinen and others, 1986, using revised ${ }^{40} \mathrm{~K}$ decay constants). This shoreline elevation estimate is unreliable, however, owing to secular resurgent deformation. Moreover, we mapped the upper limits of perlitized early rhyolite of six different dense lavas at elevations of 2,180, 2,295, 2,350, 2,400, 2,410, and $2,530 \mathrm{~m}$. (Where preserved, the pumiceous carapace of every rhyolite flow on the resurgent uplift is strongly hydrated at all elevations.) Nonhydrated obsidian crops out at many locations on the tectonically disturbed resurgent uplift, at elevations between 2,180 $\mathrm{m}$ and 2,560 $\mathrm{m}$.

In presenting their estimates of lake levels through time, Bailey and others (1976, their fig. 6) also cited what they interpreted to be lake-terrace gravels upon or adjacent to moat rhyolite lavas $(\sim 500 \mathrm{ka})$ on the south wall of the caldera's north moat (their site 12 at 2,290 m elevation and another at

Figure 5. Map showing shoreline features and deposits of Pleistocene Long Valley Lake. Elevation 2,250- and 2,500-m contours indicate base of caldera wall, delimiting caldera floor. Area underlain by siltstone facies (beige area, labeled st, central part of ancient lake), is exposed discontinuously, widely veneered by post-lake alluvium. Shown in green is present-day outcrop of littoral facies (ss)pebble conglomerate and sandstone. Both facies are overlain by alluvial fans that have encroached from north, east, and southwest since draining of the lake. Lake Crowley reservoir, dammed in 1941, is unrelated to the Pleistocene lake but shares its outlet. Red line segments with elevations are mapped remnants of highstand shoreline (sh), mostly wave-rounded pebbles and shingle. Dotted circle $10 \mathrm{~km}$ in diameter encloses postcaldera resurgent uplift, which lifted intracaldera early rhyolites $>400 \mathrm{~m}$ and mildly tilted sandstones deposited against its eastern slope; elevations of sandstone contacts are indicated. Hot Creek flow (shown in pink) is rhyolite coulee that flowed north into lake at $333 \mathrm{ka}$. Three smaller rhyolite lavas east of Hot Creek flow, all sediment-mantled, are likewise colored pink. Isolated patches of indurated sandstone (ss), loose shoreline gravel (sh), and tufa (t) are indicated by dots colored as in map explanation. Gray squares (n) mark clusters of erratics (many larger than $1 \mathrm{~m}$ ) ice-rafted across the Pleistocene lake from Sierran glaciers. Well $\mathrm{OH}-1$ in town of Mammoth Lakes penetrated lake sediments at elevations 2,078-2,135 m asl. Wells $\mathrm{CH}-1$ and $66-29$ near center of diagram are discussed extensively in text. Dash-dot line traces eastern drainage divide separating Long Valley from Owens Valley that was breached by Owens River Gorge when Long Valley Lake overflowed its threshold. Saddles 2293 and 2297 on the divide remained slightly higher than highstand of lake, which did not overflow eastward toward Chidago Canyon. Abbreviations: AR, Arcularius Ranch; BC, Benton Crossing bridge; CBR, Cashbaugh Ranch; CR, Chance Ranch; CV, Crestview; EP, East Portal of Mono craters tunnel; FV, Fumarole Valley; GP, geothermal plant at site of former Casa Diablo Hot Springs; HC, Hilton Creek; IR, Inaja Ranch; LAV, Little Antelope Valley; LHC, Little Hot Creek; LRV, Little Round Valley; hachures outline bowl eroded in Bishop Tuff; LS, Layton Springs; MC, McGee Creek; ML, downtown Mammoth Lakes; PH-1, power house \#1; SL, South Landing; TP, Toms Place; WC, Whisky Creek. For shaft 2, see figure 1. For tunnel \#1, see figure 6. All elevations shown are in meters above sea level. 

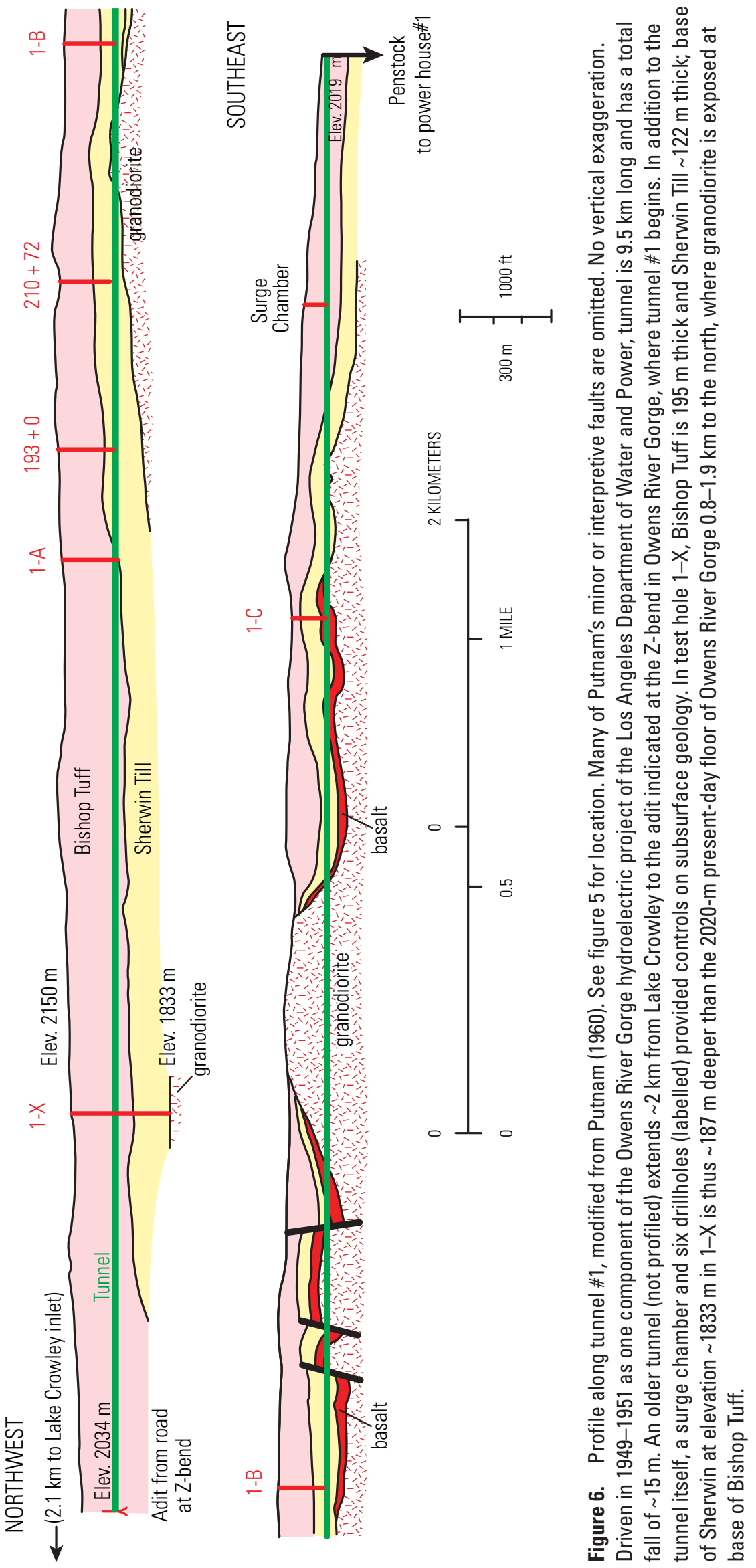
2,230 m elevation east of their site 11). Both supposed gravel patches are shown on the geologic map of Bailey (1989). After repeated scrutiny, however, we are convinced that site 12 has only road gravels and that no such deposits at all are present anywhere east of their site 11 . We agree with only two points on their figure 6, namely that the 333-ka Hot Creek rhyolite flowed into the lake and that the basaltic flow in the caldera's north moat (their site 20; unit bar of Hildreth and others, 2014; $\sim 90-100 \mathrm{ka}$ ) postdates draining of the lake. In summary, the lake-level curve of their figure 6 is untenable. They concluded that complete draining of the lake occurred "sometime within the last 0.1 m.y." (Bailey and others, 1976, p. 736), revised by Bailey (1989) to "between 100,000 and 50,000 years ago," but no plausible evidence was provided for either estimate.

We have thus undertaken a new field investigation to provide better time constraints for extinction of the lake and cutting of the gorge. The entire area was remapped in detail, on foot, over the course of several years, using 1:24,000 U.S. Geological Survey (USGS) topographic maps with 10-m contour intervals and hand-held GPS devices (continually cross-checked by the authors). The breadth of beach terraces, their uneven preservation, and encroachment of postlake colluvium from upslope create 5-10 m uncertainties in strandline elevation that would render more precise leveling to be overkill. More than 50 key shoreline elevations were subsequently determined using a Trimble Geo XH GPS, which can have vertical resolution better than $\pm 1 \mathrm{~m}$. Aerial photos were carried but were seldom useful for mapping the subtle and discontinuous features investigated.

Grid references to site locations mentioned in the text are generally given to $100 \mathrm{~m}$ using the Universal Transverse Mercator (UTM) grid (1927 North American datum, zone 11), which is shown on USGS topographic maps of the area. The first three digits are easting, and the second three are northing. All easting values should be prefixed by 03 and northing by 41 , but these initial digits are here omitted for simplicity. Occasionally, a fourth digit is added for precision to $10 \mathrm{~m}$. For example, Long Valley Dam is approximated as 4936/6127, shorthand for $0349.36 \mathrm{~km}$ east, $4161.27 \mathrm{~km}$ north.

\section{Long Valley Lake}

Shoreline deposits that mark its highstand outline a middle Pleistocene lake in Long Valley Caldera (fig. 5) that extended $16 \mathrm{~km}$ east-west (from Wilfred Canyon almost to Little Antelope Valley) and $26 \mathrm{~km}$ northwest-southeast (from Alpers Canyon to the outlet arm just east of modern Long Valley Dam). Such features include indurated sandstone, pebble conglomerate, tufa, and extensive nonindurated sheets of wellrounded gravel that mantle wave-cut terraces. A southwestern arm of the lake also extended along the caldera's south moat where sandstone crops out as far west as the site of Casa Diablo Hot Springs (now a geothermal plant). Seven kilometers west of there, at the western end of the south moat, Well OH-1 (fig. 5) penetrated a 224-m-thick sedimentary section (at depths of 321-545 m) that directly overlies the early rhyolite $(\sim 750-640 \mathrm{ka})$ and includes a 57-m-thick lacustrine sequence of sand, ashy silt, and organic-rich laminated clay, sandwiched (at elevations of 2,078-2,135 m asl) between fluvial gravels (fig. 6 of Hildreth and Fierstein, 2016).

If ever the lake had also invaded parts of the caldera's west moat, the evidence has been covered by younger lavas and glacial deposits. Several drillholes in the west moat encountered alluvium but no lake sediments above the early rhyolite (Hildreth and Fierstein, 2016). Parts of what later became the resurgent uplift were covered by lake water in early postcaldera time, but most of the evidence (other than ice-rafted dropstones and a few patches of elevated sandstone) has subsequently been stripped.

Nearly central to the outcrop area of Pleistocene lake deposits, Republic Geothermal test well 66-29 (fig. 5) penetrated $\sim 700 \mathrm{~m}$ of ash-rich lake sediments before entering intracaldera Bishop Tuff, which is itself at least 1,500 m thick (Smith and Rex, 1977; Fournier, 1989). Seismic refraction profiles (Hill, 1976) and gravity contours (Carle, 1988) suggest that the postcaldera fill is substantially thicker to the north and east of the Republic well site. The lake-sediment section is therefore likely to be even thicker than $700 \mathrm{~m}$ elsewhere - principally in the northeast part of the caldera.

The entire Long Valley drainage basin today covers $\sim 980 \mathrm{~km}^{2}$ (including Hilton but not Rock Creek), about 28 percent of which is in the Sierra Nevada, which was intermittently glaciated during the lifetime of the lake. The $330-\mathrm{km}^{2}$ surface area of the lake at its highstand would thus have occupied $\sim 33$ percent of the hydrographic basin, an unusually large fraction. Ten modern streams drain from the Sierra into the western and southern parts of the caldera (figs. 2, 5), and all are likely to have been active throughout postcaldera time. Five additional streams on the north and east sides of the caldera are ephemeral. An 11-year water budget for Long Valley (1964-1974) was compiled by Sorey and others (1978), giving $230 \times 10^{6} \mathrm{~m}^{3} / \mathrm{yr}$ from the Sierran inlet streams plus an estimate of $\sim 35 \times 10^{6} \mathrm{~m}^{3} / \mathrm{yr}$ for ungaged runoff elsewhere. Combined, these contributions are equivalent to 215,000 acre-feet/yr. Input to Long Valley Lake may have been twice as much during pluvial intervals. Paleohydrologic analysis for full-pluvial conditions at numerous Pleistocene lakes in Nevada estimates precipitation to have been $52-80$ percent greater than modern values, mean annual temperature to have been $\sim 3^{\circ} \mathrm{C}$ lower, and evaporation rate from lakes to have been $\sim 10$ percent lower (Mifflin and Wheat, 1979; Matsubara and Howard, 2009). 


\section{Shoreline Evidence}

The highstand deposits we mapped enclose an area of $\sim 330 \mathrm{~km}^{2}$. An additional area of $50-70 \mathrm{~km}^{2}$ that was later raised above lake level by structural resurgence was apparently also submerged in earliest postcaldera time, as suggested by ice-rafted erratics (discussed below). Within a central area of $\sim 100 \mathrm{~km}^{2}$, outcrops of lake deposits are mostly lacustrine siltstone (clay to fine sand), whereas peripheral exposures are largely littoral sand and gravel (figs. 7A, $B$ ), which are locally deltaic and variously indurated or not. Foreset and topset bedding in the stratigraphically youngest sandstone preserved crops out principally where the Pleistocene (necessarily longlived) courses of Convict, Hot, and Little Hot Creeks entered the lake.

Alluvial deposits that postdate draining of the lake extensively conceal the lake deposits. These include large alluvial fans from Glass Mountain on the northeast and fans from Hilton, McGee, Convict, and Laurel Creeks on the southwest. The entire southwest margin of the former lake, from South Landing to Mammoth Creek, has been blanketed by late Pleistocene alluvium, till, and lava flows, obliterating evidence of the former shorelines.

Our investigation emphasizes the highest shoreline, the highstand that we infer to have marked the onset of overflow, shrinkage, and ultimate draining of the lake. There are, in addition, six patches where closely spaced sets of 3-5 lower shorelines, best discerned in low-angle light at a distance, are weakly preserved (fig. 8; appendix 2). Five sets are on the west side of the former lake, along the toe of the resurgent uplift, and are cut on lakeward-sloping surfaces of indurated littoral sandstone and conglomerate. The sixth set is on the southeast shore of the former lake, preserved locally as laketerrace gravels that mantle a wave-planed platform of nonindurated pyroclastic deposits of Glass Mountain rhyolite, just south of Watterson Canyon. Because five of the six sets are rather weakly etched into indurated lake deposits (appendix 2) and lack all but traces of tufa, we infer that they represent short-lived regressional features (like those in seasonally drawndown reservoirs) that formed after the highstand and overflow, during progressive downcutting of the outlet and lowering of lake level.

The highstand shoreline was much better developed than the lower sets and is far better and more continuously preserved, especially along the east to southeast side of the basin. Strandline development can reflect wave energy, sediment supply, slope and lithology of the lake margins, and duration of a stable lake level (Reheis and others, 2014). The prevalence of Sierran winds and the $16-\mathrm{km}$ fetch across the lake may have been important for intensifying the eastern shoreline features at Long Valley. A second important factor is that the pre-lake eastern "bedrock" consisted largely of a nonindurated pyroclastic apron from rhyolitic Glass Mountain, wave working of which liberated the countless cobbles and pebbles of obsidian and felsite that dominate the paleo-foreshore deposits. Strong geomorphic development of the eastern highstand thus reflects a combination of lithologic, topographic, and climatic influences. Preservation of the eastern shoreline deposits is favored by the coarse rhyolitic gravels (fig. 7A) that armor wide shoreline terraces, and by the arid climate, which has permitted only a few narrow post-lake gulches to be cut by ephemeral streams across the highstand terraces.

Western shoreline deposits are not as coarse, reflecting in part their contrasting derivation from early rhyolite pyroclastic units, which are exceptionally poor in lithic clasts. The few shoreline remnants on the north side of the lake were cut on caldera-wall basement rocks. Most shoreline features along the south side have been obliterated by post-lake alluvium.

Preservation of the highstand shoreline is thus very incomplete and sectorially quite uneven (fig. 5). We measured $33 \mathrm{~km}$ of discontinuously discernible shoreline features around a periphery of roughly $111 \mathrm{~km}$, an average of 30 percent preservation. Along the east side, however, from Wilfred Canyon to Owens Gorge, shoreline preservation is $\sim 74$ percent, whereas only $\sim 12$ percent of the highstand is preserved along the south shore, from Owens Gorge to Mammoth Lakes (town). Along the north shore, from Glass Mountain to Arcularius Ranch, preservation is merely 8 percent, but a few high-quality highstand remnants are cut on caldera-wall granites. Along the north and east flanks of the resurgent uplift (west side of the lake), highstand preservation, largely represented by sandstone banked against rhyolite lavas, averages $\sim 55$ percent, but it drops to $\sim 23$ percent along the south side of the uplift.

Beach gravels and pebbly sandstones of the shoreface environment are widely exposed, but we have recognized no remnants of offshore bars, spits, bayhead barriers, or backshore ponds, dunes, or mudflats. Currents in this relatively equant lake (fig. 5) may not have been strong enough to promote much longshore transport of sand and gravel. Swash-dominated shorelines might range in primary elevation by $1-3 \mathrm{~m}$ (but seldom more; Adams and Wesnousky, 1998), owing to local topography (headlands versus coves), beach slope, or fetch, all of which would influence run-up of onshore-breaking waves.

Pebbles along the north shore are locally derived granitoids and Glass Mountain rhyolite. Along Hot Creek, Little Hot Creek, and the resurgent uplift, pebbles are derived predominantly from the early rhyolite exposed on the uplift. Littoral sandstone and conglomerate east of the Hot Creek flow consist of metasedimentary and granitoid clasts transported by Pleistocene Convict Creek from the Sierra Nevada. On both sides of the modern outlet arm of Lake Crowley, gravels and conglomerates contain a mixture of Sierran clasts and Glass Mountain rhyolites. North of the outlet arm, the proportion of Sierran clasts diminishes to nil within $1.5 \mathrm{~km}$, and for the next $13 \mathrm{~km}$ northward, east-shore gravels consist entirely of Glass Mountain rhyolite (with rare Pliocene basalt) as far as the limit of highstand preservation at Wilfred Canyon. Except near the outlet arm, where lakeshore bluffs consist of the Bishop Tuff, clasts of the caldera-forming ignimbrite are rare in the lakeshore gravels, probably because near-lake exposures are poorly welded and because intracaldera ignimbrite is buried by lake sediment hundreds of meters thick. 

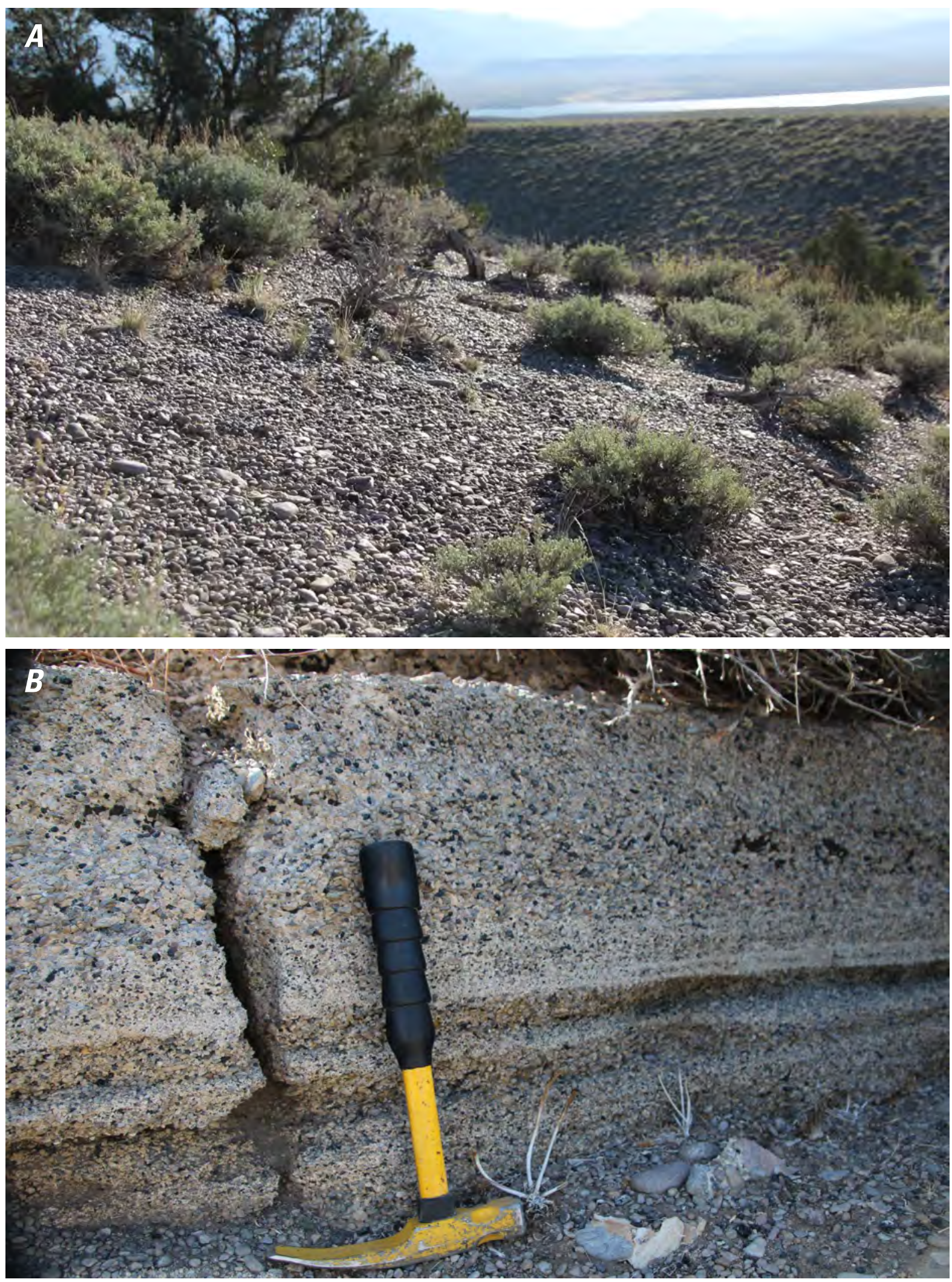

Figure 7. Typical littoral deposits along highstand shoreline along east side of Pleistocene Long Valley Lake, north of Watterson Canyon. $A$, Loose shingle characteristic of wave-washed upper limit of shoreline deposits. $B$, Nearshore pebble gravel and sandstone, plane-bedded or lenticular, carbonate-cemented; scattered beachrock outcrops are commonly $40-150 \mathrm{~m}$ lower in elevation than nearby highstand shingle. Clasts in both panels are almost exclusively rhyolite. 


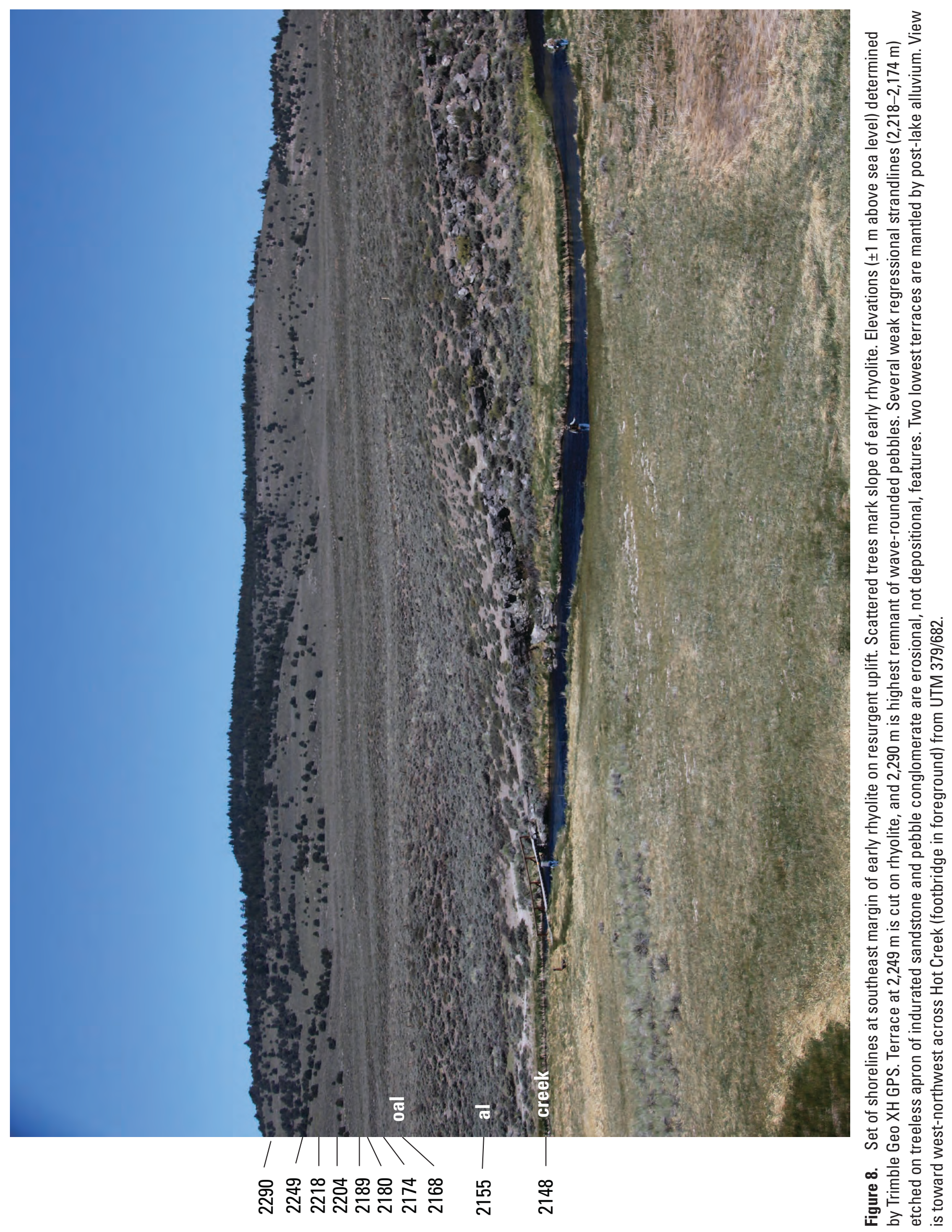


Sandstone and conglomerate along the west side of the Pleistocene lake are generally silica-cemented, reflecting their dominantly rhyolitic composition and secular hydrothermal activity around the resurgent uplift. Sandstone along the east and southeast sides of the lake, however, as well as most of the siltstone (centrally exposed and in wells), is carbonate-cemented.

Coarse sediment provenance is relatively easy to recognize at Long Valley owing to the distinctive basement and volcanic lithologies, their limited variety, their well-known sectorial distribution (Hildreth and Mahood, 1986; Bailey, 1989; Greene and Stevens, 2002), and to the circumscribed limits of the compact $980-\mathrm{km}^{2}$ drainage basin (figs. 1, 2).

\section{Elevations and Deformation of the Highstand}

Deposits that mark the highest shoreline range remarkably in elevation (fig. 5), providing a natural tiltmeter. Along the north wall of the caldera, remnants are few, but tufa crops out at elevations of 2,270 $\mathrm{m}$ and 2,140-2,170 m, sandstone from $2,165 \mathrm{~m}$ to $2,245 \mathrm{~m}$, and three patches of well-rounded gravels as high as 2,200 m, 2,260 m, and 2,265 m. No shoreline evidence survives across the alluviated foot of Glass Mountain, but from Wilfred Canyon southward, highstand gravels are essentially continuous for $14 \mathrm{~km}$ along the former east shore, as far as the lake's outlet arm. These form extensive sheets of unconsolidated shingle - well-rounded rhyolite cobbles and pebbles (fig. 7A) - that armor gently sloping strands planed on Glass Mountain pyroclastic deposits. Locally, beach gravels grade downslope into shoreface sand and gravel that are typically plane-stratified or lenticular and in most exposures carbonate-cemented (fig. 7B).

Below the high strandline north of Watterson Canyon, the sand/gravel-clad lakeshore terrace is $1-2 \mathrm{~km}$ wide, is developed entirely on the Glass Mountain pyroclastic fan, and its patchy exposures have a vertical range of 80-140 m (fig. 5). South of Watterson Canyon, where planed on welded Bishop Tuff, as well as on nonindurated Glass Mountain pyroclastic deposits, its exposed vertical range is similar, but terrace width is widely $2-3 \mathrm{~km}$. The width of the foreshoreshoreface surface probably reflects gradual transgression of the deepening lake, but some of its present-day range in elevation owes also to post-lake deformation.

Near Wilfred Canyon and for $3.5 \mathrm{~km}$ south, wellrounded wave-worked gravels extend to elevations as high as 2,335 $\mathrm{m}$ asl (figs. 5, 9). Over the next $5 \mathrm{~km}$ southward, however, the well-marked upper limit of such gravels descends gradually to $2,300 \mathrm{~m}$ just north of the Watterson Troughs arroyo and to 2,280 m just north of the Watterson Canyon highway (figs. 5, 9). Over the next $1.5 \mathrm{~km}$, south of Watterson Canyon, the upper limit of highstand gravels declines more steeply, from $\sim 2,270 \mathrm{~m}$ to $2,200 \mathrm{~m}$ (figs. 5, 9), where the shoreline merges into a 50-m-high wave-cut scarp of welded Bishop Tuff (fig. 10). This ignimbrite scarp (which is not a fault) trends linearly southwest for $3.5 \mathrm{~km}$ before bending abruptly into a southeast-trending reach that extends $2.5 \mathrm{~km}$ to the rim of Owens Gorge (figs. 5, 11). No lake gravels are present on the plateau above the scarp. The toe of the 6-km-long scarp descends from 2,200 $\mathrm{m}$ at its northeast end to $\sim 2,160 \mathrm{~m}$ at the bend (fig. 10). Along the north rim of Owens Gorge, unconsolidated shoreline gravels and indurated plane-bedded pebbly sandstones (beachrock) are preserved as far as $2.4 \mathrm{~km}$ east of Long Valley Dam, displaying along this reach a fairly continuous upper limit at 2,145-2,150 m. The downstream-most patch of wellrounded gravels on the gorge rim extends $\sim 10 \mathrm{~m}$ higher, as high as $2,158 \mathrm{~m}$ asl, perhaps reflecting either storm effects along the inlet or a small component of westward (lakeward) tilting accompanying the main southward tilting. The essentially continuous high shoreline of Long Valley Lake has thus been downwarped southward as much as $185 \mathrm{~m}$ over a distance of $13-14 \mathrm{~km}$, an average slope of $\sim 0.8-0.9^{\circ}$ (figs. 5, 9, 10).

Along the former west shore, littoral sandstone, pebble conglomerate, and rounded beach gravels are preserved at elevations as high as 2,230 m near the Casa Diablo geothermal plant, 2,200 m near the mouth of Fumarole Valley, and 2,290 m north of Hot Creek opposite the Fish Hatchery (fig. 5); these three sites are all on the edge of the resurgent uplift. Indurated lake deposits are also banked against the 333 -ka rhyolitic Hot Creek flow, at elevations of 2,140 m to $\sim 2,160 \mathrm{~m}$ around most its periphery, except at its northwest corner where resurgence tilted the flow margin and its shoreline sediments as high as $\sim 2,200 \mathrm{~m}$.

Northward along the east side of the caldera's resurgent uplift, several patches of bedded sandstone are preserved as high as 2,250,2,260, and 2,290 m (fig. 5). At the northeast margin of the resurgent uplift, the toe of a 50-m-high wavecut scarp in early rhyolite extends $\sim 1 \mathrm{~km} \mathrm{WNW}$. at an elevation of $\sim 2,195 \mathrm{~m}$, and littoral sandstone laps onto a shelf of massive perlitized rhyolite at 2,160-2,190 m. All of these lakeshore features are as high or higher in elevation than the 2,150-2,160-m upper limit of shoreline deposits along the lake's outlet arm. Some of the west-shore excess elevation certainly reflects upwarping along the edge of the rhyolitic resurgent structure, but much of the elevation difference owes to downwarping of the outlet arm.

\section{Outlet Arm of the Pleistocene Lake}

The outlet arm of Pleistocene Long Valley Lake was drowned by closure of 38-m-high Long Valley Dam in 1941 and filling of Lake Crowley reservoir (fig. 12). A 1937 topographic map surveyed for the City of Los Angeles portrays the pre-reservoir Owens River meandering along a broad floodplain as far as the confluence of Convict Creek, shortly below which the now-drowned river entered a steepwalled channel that extended $3 \mathrm{~km}$ to the dam site, bending from southward to eastward. The channel narrowed downstream, from $\sim 180 \mathrm{~m}$ wide at its head to $120 \mathrm{~m}$ opposite Whisky Creek to $<100 \mathrm{~m}$ wide near the dam. Incised 7-11 $\mathrm{m}$ below adjacent drowned shelves, the channel deepened 

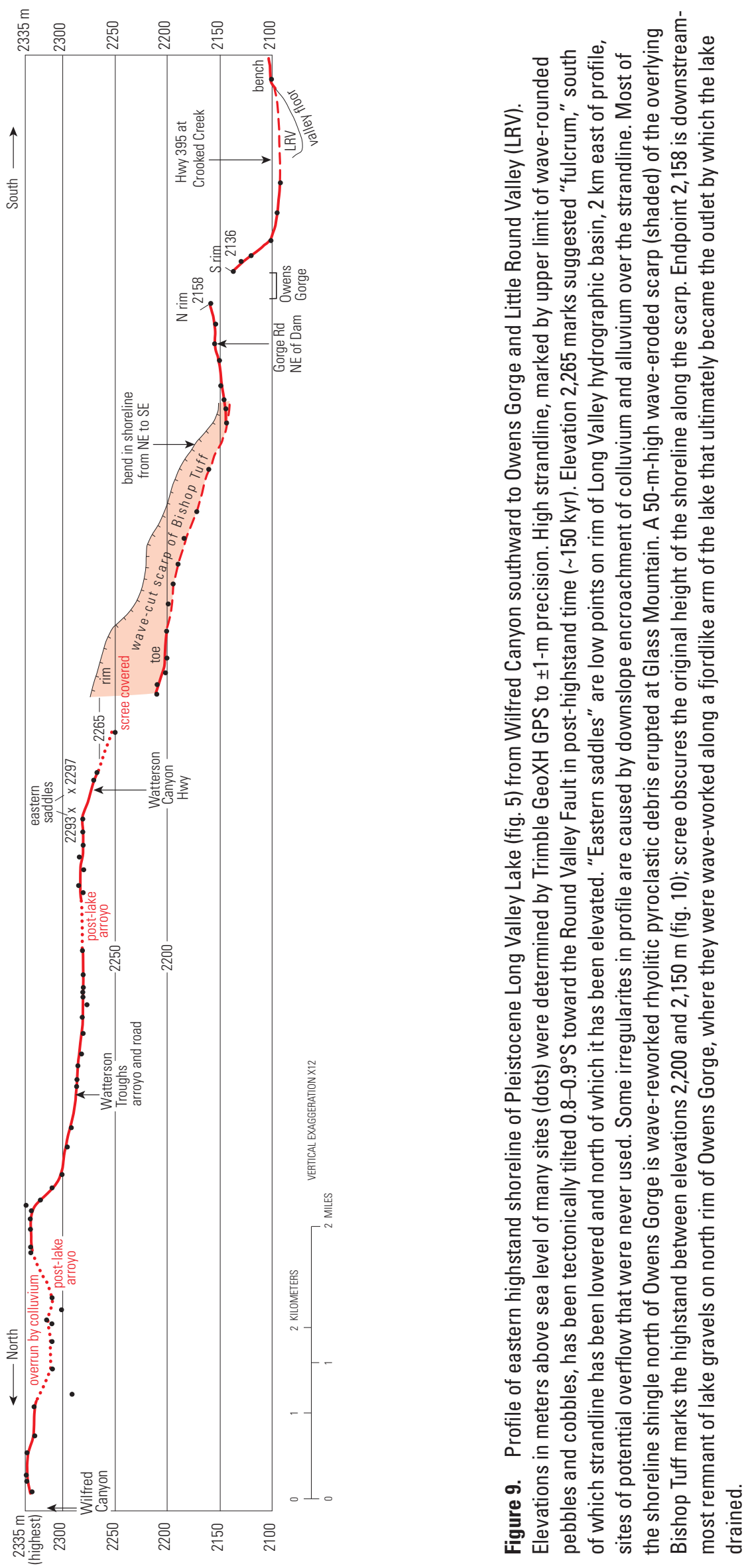


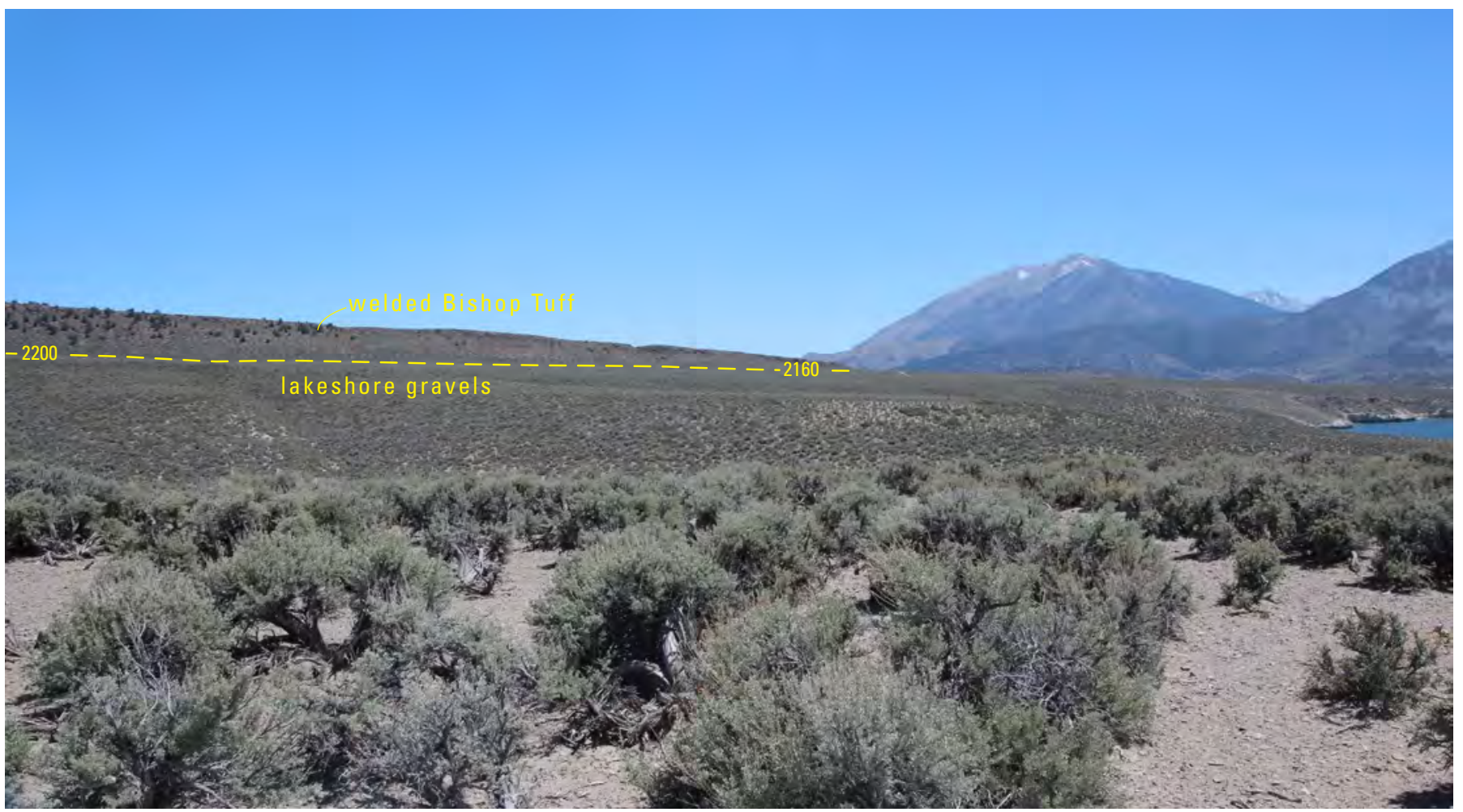

Figure 10. Highstand shoreline (dashed line) along southeast margin of Pleistocene Long Valley Lake, following base of 40-to-50-mhigh wave-cut scarp of welded Bishop Tuff (sprinkled with trees). Broad bench below scarp is wave-planed terrace cut on pyroclastic fan of Glass Mountain rhyolite and is covered by several meters of wave-rounded rhyolitic gravel (shoreline shingle). Strandline has been tilted down $0.8-0.9^{\circ}$ to the right (elevations in meters above sea level), toward outlet arm of the Pleistocene lake. View southward to Wheeler Crest and Sierran canyon of Rock Creek. Lake Crowley reservoir at right, bordered by cliff of white nonwelded Bishop Tuff.

downstream-from $\sim 19$ m below present-day "normal pool" level of the reservoir to $\sim 23 \mathrm{~m}$ deep opposite Whisky Creek to $\sim 25 \mathrm{~m}$ at the dam. After meandering along the floor of the channel as far as Crooked Creek, $600 \mathrm{~m}$ west of the dam, the river straightened into a deep narrow gorge walled by Bishop Tuff (fig. 11). The now-drowned eastward reach of the outlet arm extended $2 \mathrm{~km}$ from the confluence of Whisky Creek to the dam site. Lake-terrace gravels are preserved along both sides of the outlet arm and on both rims of the gorge for an additional $2.4 \mathrm{~km}$ east of the dam. At the highstand, a narrow embayment of Pleistocene Long Valley Lake was thus at least $4.4 \mathrm{~km}$ long and led directly to the site where incision of Owens Gorge subsequently drained the lake (figs. 5, 11).

Along the outlet arm of the lake, which coincides with the entrance to Owens Gorge, the highstand shoreline of Long Valley Lake reached a maximum elevation (on the present-day landscape) of 2,150-2,160 m before the canyon cutting that drained it. As described above, however, this is $175-185 \mathrm{~m}$ lower than the present elevation of the same continuous shoreline $\sim 14 \mathrm{~km}$ north, requiring tilting of the shoreline by an average of $0.8-0.9^{\circ}$ since breakout of the lake and regression from its highstand. The same shoreline continues south from the outlet arm along the rim of Crooked Creek gorge into Little Round Valley (figs. 5, 9, 11). Here, however, 3-4 km southwest of the 2,150-m strandline north of the outlet arm, the upper limit of shoreline features is only $\sim 2,100 \mathrm{~m}$. An additional $50 \mathrm{~m}$ of downwarping over a distance of $3.5 \mathrm{~km}$ indicates southward tilting of the shoreline by $\sim 0.8^{\circ}$, similar to that observed for the entire $14-\mathrm{km}$-long strandline east of Long Valley Lake and north of its outlet arm. Downwarping of Little Round Valley by $\sim 50 \mathrm{~m}$ relative to the 2,150-m high strandline at the outlet arm had to have taken place after draining (or major shrinkage) of the lake, because a Little Round Valley lake embayment at a level of 2,150 m should have drained eastward via Toms Place into Rock Creek, and there is no evidence that it did so. To the contrary, then as now, distributaries of Rock Creek flow northwest via Little Round Valley and lower Crooked Creek into Long Valley's outlet arm.

\section{Unbreached Low Eastern Divide Enclosing Long Valley Basin}

The highest point surviving along the Owens Gorge rim is $5.3 \mathrm{~km}$ downstream (east) of the dam, at an elevation of $\sim 2,230 \mathrm{~m}, 230 \mathrm{~m}$ above the gorge floor and $70-80 \mathrm{~m}$ higher than the highstand shoreline of the Pleistocene lake at the upper entrance to the gorge (figs. 3,11). When the lake began draining along the channel that deepened to become the modern gorge, this was the low point along all Quaternary divides enclosing the Long Valley hydrographic basin. (Owing 


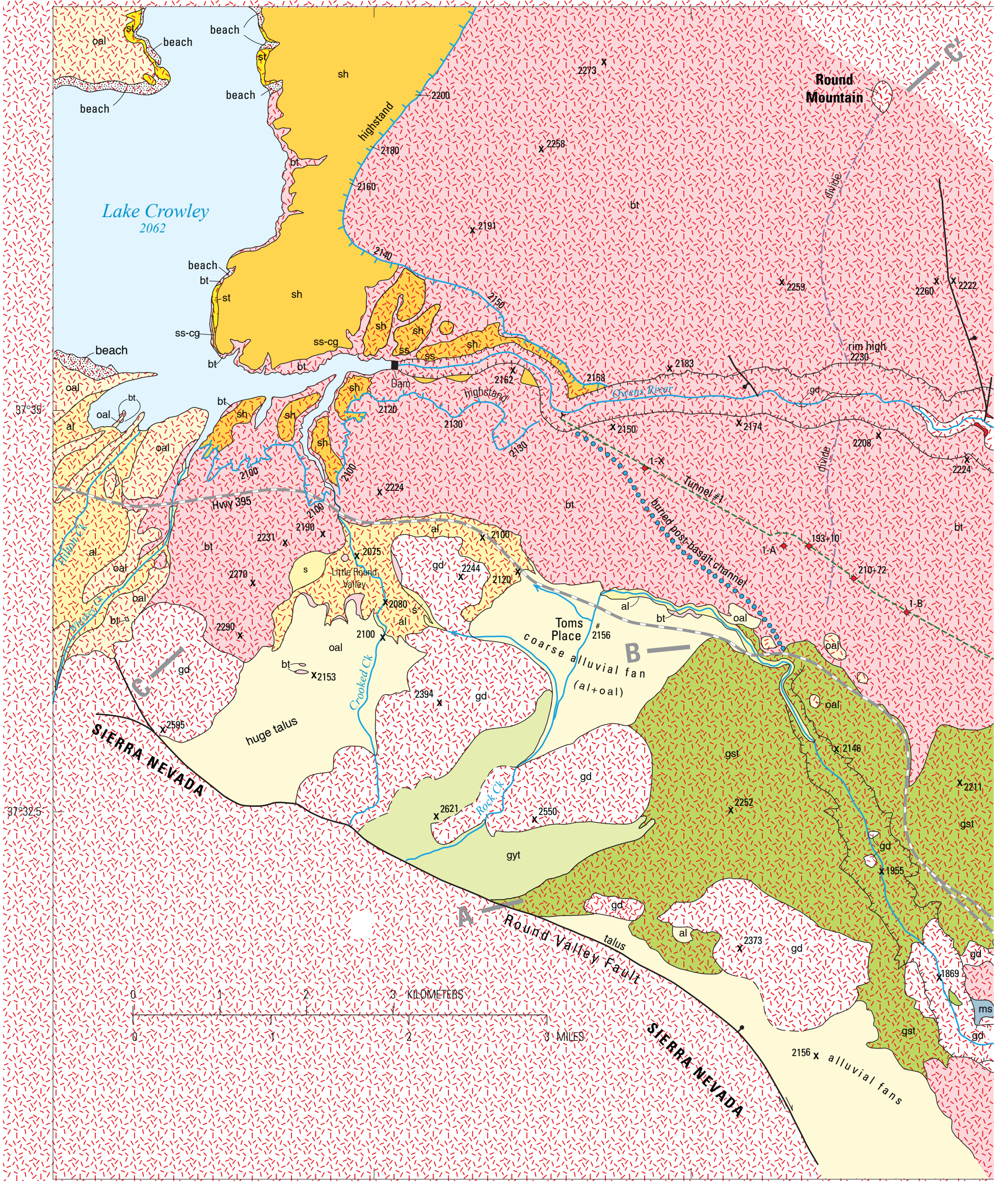



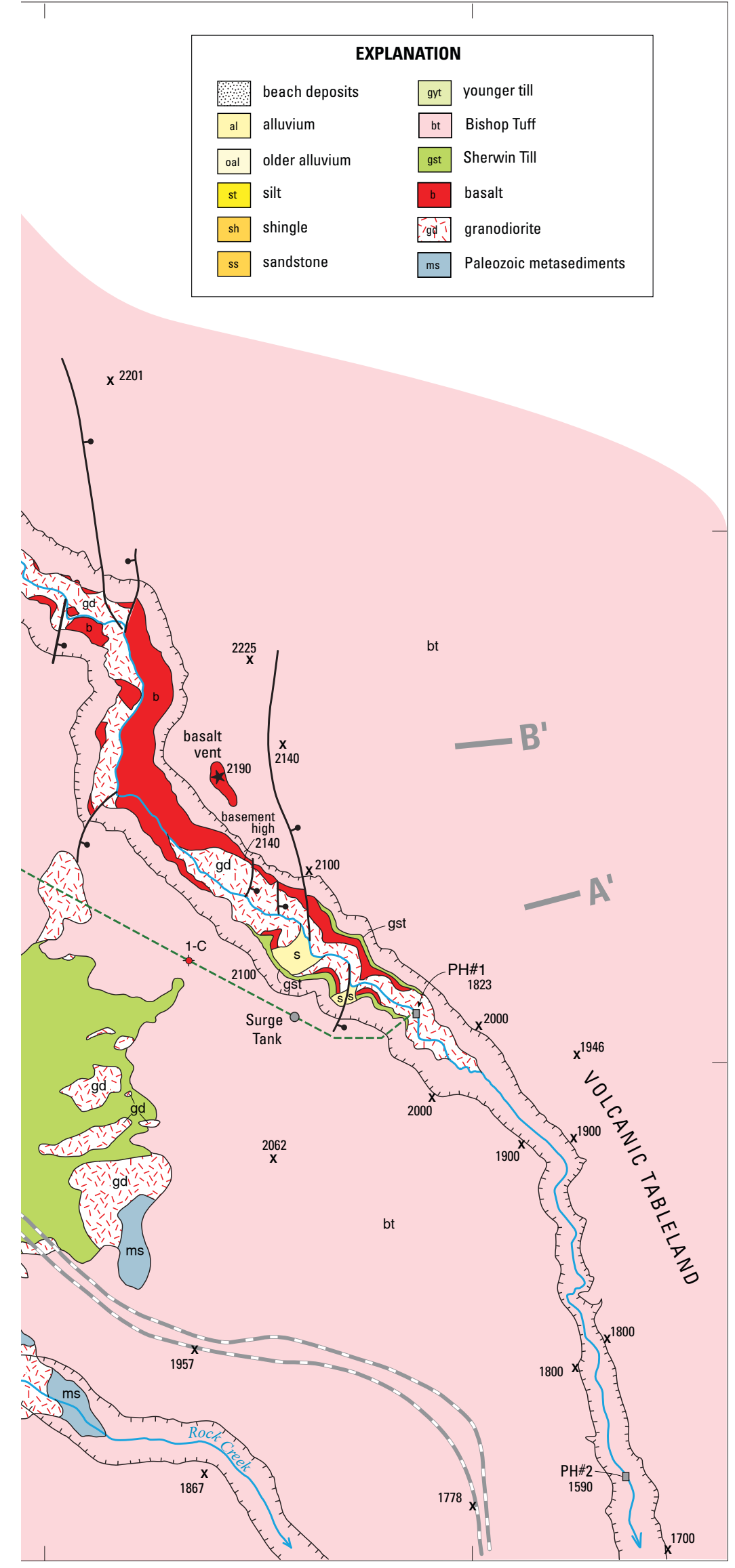

Figure 11. Geologic map of upper Owens Gorge and Rock Creek Gorge (fieldwork by authors 2012-2015), emphasizing highstand shoreline features of Pleistocene Long Valley Lake (hachured blue line), upper $18 \mathrm{~km}$ of Owens Gorge, and courses of both gorges through the basement paleoridge. Spot elevations $(x)$ in meters above sea level. Also shown are Sherwin Till outcrop area and hypothesized pre-Sherwin channel of Owens River diverted by 3.3-Ma basaltic shield (vent marked by star) and buried first by till and later by Bishop Tuff. Route of tunnel \#1 (green dashed line) and wells along it (red dots) are as in figures 5 and 6 . Map-unit symbols: al—alluvium; oal—inactive older alluvium; $b-3.3-\mathrm{Ma}$ basalt; bt—767-ka Bishop Tuff; gd—Triassic granodiorite; ms-Paleozoic metasedimentary rocks; s-surficial colluvial deposits, undivided; sh-middle Pleistocene shoreline gravels; ss-cg — sandstone and conglomerate of Pleistocene Long Valley Lake; st-silt and siltstone of Pleistocene Long Valley Lake; gst-early Pleistocene Sherwin Till; gyt-younger till of Tahoe and Tioga Glaciations. Endlines $A-A^{\prime}, B-B^{\prime}$, and $C-C^{\prime}$ locate crosssections of figure 15. $\mathrm{PH}$, power house. 


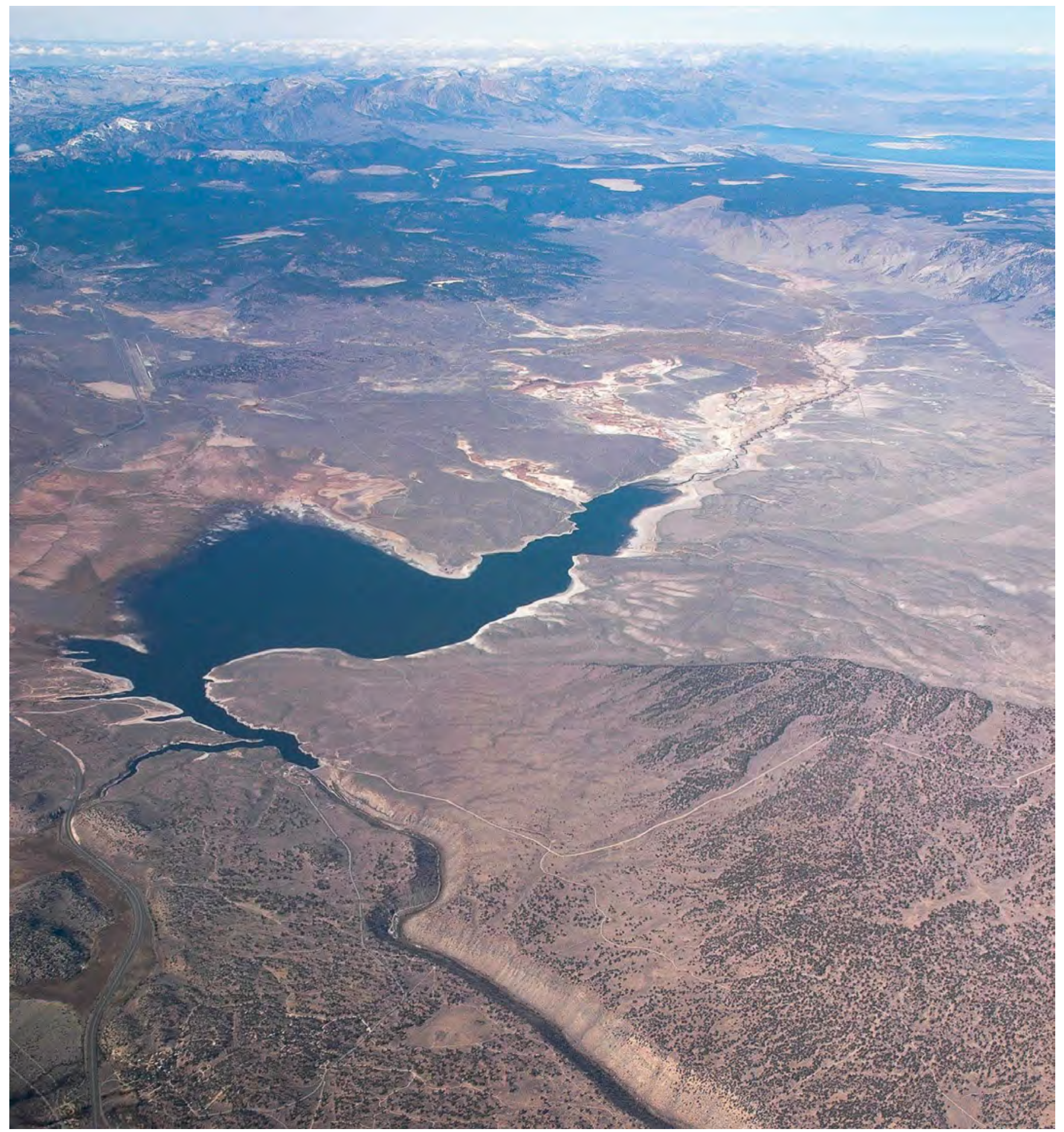

Figure 12. Panorama, looking northwest, of Lake Crowley reservoir and intracaldera basin of Pleistocene Long Valley Lake, highlighted by exposures of white lake silt, which are widely veneered by thin gray post-lake alluvium. Outlet arm and its Crooked Creek tributary lead eastward into Owens Gorge (see figs. 1, 3, 5, 11). Smooth wave-planed benches on both sides of outlet arm are mantled by middle Pleistocene littoral gravels, contrasting in foreground with raggedly eroded Bishop Tuff, which stood above highstand of Pleistocene lake. North wall of caldera in middle distance at right. Forested resurgent uplift of caldera in upper left. Sierra Nevada and Mono Lake $\sim 60 \mathrm{~km}$ to northwest. Aerial oblique photo courtesy of Allen Glazner. 
to southward post-highstand tectonic tilting and to erosive stripping of at least $50 \mathrm{~m}$ of the ignimbrite surface, the Rock Creek valley downstream from Toms Place is today substantially lower (fig. 11) than the divide breached by the Owens River when the lake overflowed. Had the alternative Rock Creek route been that low when the lake reached its highstand, Owens Gorge would not have been cut.)

No other point on the south, west, north, or northeast walls of Long Valley is lower than 2,445 m (Deadman Summit), but to the east there is a potential lake threshold near the head of Watterson Canyon where a pair of saddles at present elevations of 2,293 $\mathrm{m}$ and 2,297 $\mathrm{m}$ (by Trimble GPS; $\sim 6 \mathrm{~m}$ higher than shown on the topographic map) are the low points on the divide separating Long Valley from Chidago Canyon (figs. 5, 9). We have found no evidence within (or east or west of) these saddles for lake overflow or any dividecrossing paleodrainage. Smooth colluvium-mantled arroyos on both sides of the divide were cut by ephemeral runoff into an extensive fan of unconsolidated rhyolitic pyroclastic debris from Glass Mountain. Overflow would have rapidly cut a substantial channel into the loose rhyolite tuff.

About $2 \mathrm{~km}$ west of the saddles, however, the high strandline makes a close approach to the eastern divide. Its gravelly terraces are there cut at elevations of 2,283-2,287 m into granitic knolls that extend higher than the pyroclastic fan. Unless fortuitous, similarity of the highstand elevation to that of the divide $2 \mathrm{~km}$ east raises the possibility that subsurface leakage through fractures in the granite had limited further rise of the lake level, restraining it from surmounting the pyroclastic divide. A similar limitation on lake level by leakage through a permeable layer on the caldera wall was reported by Nathenson and others (2007) at Crater Lake, Oregon.

An important additional issue raised by an unbreached eastern divide at $\sim 2,293 \mathrm{~m}$, barely higher than the local shoreline, is its elevation $20-45 \mathrm{~m}$ lower than the same continuous shoreline 5-9 km north (where it is preserved as far as Wilfred Canyon). The fact that the $\sim 2,285-\mathrm{m}$ reach of the highstand ( $2 \mathrm{~km}$ west of potential thresholds at the 2,293-m and 2,297-m saddles) is $135 \mathrm{~m}$ higher than the highstand shoreline $(2,150 \mathrm{~m})$ at the outlet arm can be explained by southward tectonic tilting after shrinkage or extinction of the lake. The fact that the same shoreline rises northward to as much as $40 \mathrm{~m}$ higher ( 2,335 $\mathrm{m}$ at Wilfred Canyon) than the unutilized saddles of potential eastward overflow requires (subsequent to draining of the lake) either (1) relative uplift of the northern reach that extends to Wilfred Canyon and Glass Mountain or (2) southward block tilting of the whole region from Glass Mountain to Owens Gorge. Alternative (1) is favored by the following observations.

The fact that the highstand shoreline near Wilfred Canyon $(2,335 \mathrm{~m})$ is also higher than the highest shoreline features on the north $(2,265-2,270 \mathrm{~m})$ and west $(2,290 \mathrm{~m})$ sides of the former lake favors post-lake uplift of the Glass Mountain area. Five GPS stations, 3-8 km east of Long Valley Caldera and either on or just south of the Glass Mountain edifice, record recent and ongoing uplift rates between 0.5 and $2 \mathrm{~mm} / \mathrm{yr}$. The vertical velocity field was obtained by retrieving GPS station velocities from the USGS (http:// earthquake.usgs.gov/monitoring/gps/LongValley/velocities/) in a North America-fixed reference frame. Station WATC, for example, outside the east rim of Long Valley Caldera, is uplifting by $1.92 \pm 0.28 \mathrm{~mm} / \mathrm{yr}$ and is consistent with the other nearby stations. If such uplift, averaging $\sim 1 \mathrm{~m} / \mathrm{k}$.y., had differentially affected the extracaldera region north of Watterson Canyon, the excess $40-50 \mathrm{~m}$ at Wilfred Canyon could have been produced in less than 50 k.y.

If this analysis is correct and if the highstand shoreline $(\sim 2,265 \mathrm{~m})$ cut on the caldera's granitic north wall is undeformed, then one can envision a "fulcrum" (or hingeline) near Watterson Canyon at $\sim 2,265 \mathrm{~m}$ along the eastern highstand (fig. 9), north of which the shoreline has tilted up to $2,335 \mathrm{~m}$ and south of which it has tilted down to the outlet at 2,150 $\mathrm{m}$. Along the west side of the lake, shoreline deposits were elevated by resurgence (to as high as 2,290 m), so the few shoreline features along the granitic north wall may provide the only indicator of highstand lake level that survives unmodified - except the inferred east-side fulcrum itself. As discussed below in the section "Overflow and Draining of Long Valley Lake," draining of the lake, modest in areal extent and not very deep, is unlikely to have promoted much isostatic rebound, and, because none has been detected, the deformation observed apparently reflects regional tectonics (and magmatic resurgence), not isostasy.

\section{Erratics along Deformed Shorelines}

Pebbles and cobbles in unconsolidated lakeshore gravels and in littoral conglomerates are predominantly of local sectorial derivation - Glass Mountain rhyolite along the east shore, early rhyolite along the west shore, various calderawall lithologies along the north shore, and Sierran basement lithologies near the outlet arm. Scattered boulders, however, mostly 30-130 m lower in elevation than highstand shorelines, occur singly or in small clusters and are nearly all of Sierran origin and manifestly anomalous. Along the eastern highstand, between Wilfred and Watterson Canyons where the gravels are rhyolitic, we mapped 15 separate sites (at 2,240-2,300 m elevations; fig. 5) where granitic, metasedimentary, and metavolcanic boulders had docked - many within what had been coves of the Pleistocene lake. Boulders $25-50 \mathrm{~cm}$ across of each lithology are abundant, but some granodiorites are as big as $2.5 \mathrm{~m}$, granites and metavolcanics $2 \mathrm{~m}$, and metapelites as big as $1.3 \mathrm{~m}$. We can envision no process but rafting across the lake in or on icebergs calved from Sierran glaciers that could have delivered such material to the east shore.

South of Watterson Canyon, where the warped highstand descends toward the outlet arm (fig. 9), we mapped 17 more separate sites (at elevations 2,060-2,245 m; fig. $5)$ marked by boulders $(25-260 \mathrm{~cm}$ across) that consist of 
Round Valley Peak Granodiorite, Wheeler Crest Granodiorite, quartzite, metapelite, and varied metavolcanic lithologies. All are derived from glaciated parts of the Sierra Nevada above the south margin of the caldera.

The west shoreline of Pleistocene Long Valley Lake, which was cut on east-facing early rhyolite exposed on the caldera's resurgent uplift, carries few such erratics. In contrast, the west side of the resurgent uplift carries many. Along the north-trending ridge of early rhyolite (west of Highway 395) that faces the caldera's west moat, we mapped seven separate sites (at elevations 2,430-2,490 m) marked by boulders $(25-150 \mathrm{~cm})$ of Round Valley Peak Granodiorite, leucogranite, Mono Creek Granite, and metavolcanic lithologies. The first two were ice-quarried from the caldera's south wall and the other two from Sierran cirques south of Mammoth Mountain. The elevations of these clusters of erratics, much higher than any paleoshoreline, requires post-emplacement uplift by structural resurgence.

Likewise west-facing, the faulted ridge of early rhyolite east of the geothermal plant (fig. 5; formerly Casa Diablo Hot Springs) is marked by at least six sites (at 2,310-2,360 m) carrying scattered boulders $(40-200 \mathrm{~cm})$ of the same four lithologies. The asymmetric distribution of erratic boulders, common along the west-facing side of the resurgent uplift but rare along its east-facing paleoshoreline, suggests the influence of katabatic winds in driving icebergs from Sierran glaciers eastward across the lake.

The four main kinds of erratics on the resurgent uplift were all sourced in the Sierra Nevada south and southwest of Mammoth Creek. Erratics on the east side of the Pleistocene lake, in contrast, are more varied, including quartzite, argillite, siliceous hornfels, metavolcanics, Wheeler Crest Granodiorite, and at least two other granitoids, indicating glacial sources in Convict, McGee, or Hilton Creeks. The erratics uplifted by resurgence were probably deposited during a glaciation fairly early in the lake's lifetime. Those along the east side of the lake could have been emplaced during any glacial episode, up to and including that of early MIS 6.

Rare blocks of Glass Mountain lava not far below the eastern highstand shoreline were transported by precaldera pyroclastic flows. Otherwise, all of the many hundreds of erratics encountered are of pre-Cenozoic basement lithologies, whether east of the lake or on the resurgent uplift. Absence of erratics from the glaciated Mammoth Mountain edifice (100$50 \mathrm{ka}$; Hildreth and others, 2014) excludes across-lake iceberg transport during MIS 2 and MIS 4 glacial episodes. The apparent lack of basaltic erratics from sequences of glaciated mafic lava flows that floor the caldera's west and south moats (230 ka and younger; Hildreth and others, 2014) suggests that transport of erratics from the Mammoth Lakes embayment took place earlier than MIS 6 (191-130 ka).

\section{Sedimentary Deposits of Long Valley Lake}

Although at least $700 \mathrm{~m}$ of lacustrine fill accumulated atop the intracaldera Bishop Tuff, no surface exposure of the lake sediments is thicker than $25 \mathrm{~m}$. The sediments consist of two contrasting facies - sands and gravels peripheral to the lake and silts central to the lake (fig. 5).

A littoral apron of well-cemented sandstone, grit, and pebble conglomerate slopes gently toward the lake and today crops out principally along the west side of the basin (Rinehart and Ross, 1964; Bailey, 1989). The north, northeast, and southwest sides are largely covered by post-lake alluvium. Along the east to southeast side, exposures of indurated sandstone and grit are relatively sparse owing to alluvial cover, but a broad swath of unconsolidated highstand shingle (described above) is virtually continuous for $14 \mathrm{~km}$.

The indurated strata range from laminae to beds as thick as $30 \mathrm{~cm}$; most are planar or low-angle lenticular, but locally some are cross-bedded or deltaic foresets and topsets. Sorting is moderate to good, but average grain size of alternating layers ranges widely from medium sand to pebble gravel. Subordinate layers of fine sand and silt are common distally, and conglomeratic layers are more abundant shoreward. Less well-sorted layers of sand and gravel, especially within the deltaic facies that issued from Convict, Hot, and Little Hot Creeks, may represent storm-fed channelized debris flows that entered the lake.

Because much of the coarse sediment was derived from phenocryst-poor rhyolite, many pebbles and sand grains are glassy, devitrified, or pumiceous rhyolite (along with derivative plagioclase and sparse biotite), whereas most quartz and many feldspar grains are likely to have come from Sierran granitic sources. Some obsidian clasts are angular or subangular, reflecting both breakability and nearby provenance, but most of the rhyolitic shoreline shingle is well-rounded (fig. 7A). Sand grains range from subangular to subrounded. Southeast of the Hot Creek flow (fig. 5), Sierran sources provided a greater contribution of sand and gravel of granitic and metasedimentary origin.

The coarse siliciclastic facies overlies and interfingers distally with ash-rich, fine-grained, diatom-and-ostracodbearing lacustrine silt and siltstone, which dominate exposures in the middle part of the former lake basin (Rinehart and Ross, 1964; Bailey, 1989). The cream-white to pale gray clay, silt, and fine sand are horizontally layered, laminated to thin bedded (locally rather vaguely so), and weakly indurated. In some sections, what otherwise appears to be massive white silt is subdivided into horizontal zones $5-200 \mathrm{~mm}$ thick by horizons stained pale-orange or tan that coincide with no obvious discontinuity or change in grain size. Puffy surface crusts decimeters thick, promoted by swelling clays, typically conceal the well-bedded deposits. Exposures are generally 10-25 m 
thick, their upper surfaces commonly armored by sandstone or post-lake veneers of pebbly alluvium.

A large proportion of the fine sediment was derived from rhyolitic ash - from the early rhyolite on the west, which is widely exposed on the caldera's resurgent uplift, and from the precaldera Glass Mountain pyroclastic fan on the east. In earliest postcaldera time, erosion of nonwelded Bishop Tuff probably dominated basal lake sediments, now deeply buried. During glacial episodes in the Sierra, significant fractions of the fines were no doubt contributed by meltwater that carried suspended silt and clay-sized silicate flour. Many or most layers of the silty sediments exposed contain 10-20 percent diatoms and ostracods dispersed among the dominant glass and mineral particles. Breakage of diatom frustules and ostracod valves suggests wave or current transport of the sediments in shallow water. Commonly intercalated are tan layers, $10-30 \mathrm{~mm}$ thick, that consist almost entirely of ostracod shells and white very fine-grained layers that are almost pure diatomite, both kinds apparently representing transient blooms rapidly followed by nutrient depletion and die-off. Mafic and silicic tephra layers, 1-30 mm thick and commonly ferricreted, are also widely intercalated in the exposed siltstone. Unconformities within the exposed siltstone are rare or absent, but pinch-and-swell of tephra laminae suggests either bottom currents or softsediment sagging.

Where preserved on flat-topped hillocks in the Long Valley lowland, upper surfaces of the siltstone (armored by thin veneers of alluvial gravel) all have elevations of 2,090 $2,115 \mathrm{~m}$. Toward the western lakeshore, however, between Hot Creek and Little Hot Creek, exposures of the sandstone/ siltstone contact climb as high as $2,160 \mathrm{~m}$ (possibly influenced by resurgent uplift). Roughly accordant surfaces of most siltstone hills and ridges in the former center of the lake, at elevations 35-60 m lower than the 2,150-m highstand shoreline at the outlet arm, are suggestive of lake water depth at the time of overflow and draining (and therefore at a time near the end of lacustrine silt deposition). As suggested by the 2,160 m siltstone surfaces south of Little Hot Creek, however, it might alternatively be that tens of meters of silt have been eroded from the lowland hillocks (by the meandering Owens River) in post-lake time, which would imply a considerably shallower lake $(\sim 10-20 \mathrm{~m})$. A third possibility is that the $2,265-\mathrm{m}$ shoreline on the caldera's north wall permits the lake, at some stage, to have been $\sim 150$ m deep. Any of these inferences would depend critically on taking account of the unknown amounts of post-lake differential deformation of the lake's outlet, central floor, western margin, and north wall.

\section{Drillholes into Lake Sediments and Paleoenvironmental Interpretations}

Two deep drillholes (fig. 5) penetrated significant sections of the postcaldera sediments deposited in Long
Valley Lake. Republic Geothermal test well 66-29 (UTM 034160/416885; Smith and Rex, 1977), 10.5 km northwest of Long Valley Dam and $\sim 4 \mathrm{~km}$ west of the center of the lake basin, penetrated almost $700 \mathrm{~m}$ of lake sediments and tuffs that overlie thick intracaldera Bishop Tuff. Research well CH-1 (UTM 033945/417145; Lewis, 1975), $14 \mathrm{~km}$ northwest of the dam and $3 \mathrm{~km}$ east of the west shore of the lake, provided core of lake sediment to a depth of $305 \mathrm{~m}$. Cuttings from the first and core from the second were described in detail by Fournier (1989), whose investigation emphasized the secondary mineralogy.

\section{Nature of Sediments Drilled}

The top $\sim 69 \mathrm{~m}$ of the CH-1 core (Lewis, 1975) is mostly silica-cemented rhyolitic sandstone and pebble conglomerate in massive or graded beds and lenses, some of them steeply crossbedded (partly deltaic), along with thin interbeds $(<1 \mathrm{~m})$ of ashy silt. Successively deeper are $56 \mathrm{~m}$ of massive to thin-bedded ashy silt, fine sand, and diatomite that are well-sorted and contain a few graded beds; $38 \mathrm{~m}$ of well-sorted lenticular gravel and sand that has some graded beds and a few thin interlayers of ashy silt and diatomite; $98 \mathrm{~m}$ of alternating well-sorted sandstone and rhyolite-pebble conglomerate, including cross-bedded sands, graded beds, and thin layers of ashy silt; and $44 \mathrm{~m}$ of massive to thin-bedded siltstone that contains ostracods and pumice-bearing tuff, extensively clay-altered and locally rich in fine, dark organic material. Pebbles of obsidian and pumice are abundant in the coarser layers. Logs by R.A. Bailey and R.E. Lewis suggest abundant reworked ash and small pumice clasts but few or no primary pyroclastic deposits (Lewis, 1975). Diatoms and ostracods, graded bedding, cross bedding, varve-like laminar couplets, and soft-sediment deformation confirm that all or most of the "tuff" described by Fournier (1989) are sediments derived from the voluminous early rhyolite pyroclastic deposits. Ostracods were identified at many intervals throughout the core and diatoms at well depths of 100-150 m.

The Republic well 66-29 penetrated sandstone and pebble conglomerate to a depth of $\sim 135 \mathrm{~m}$, then remained in interbedded tuff, sandstone, and fine-grained sediment for $\sim 700 \mathrm{~m}$, entered welded Bishop Tuff at a depth of $\sim 838 \mathrm{~m}$, and bottomed (still in Bishop Tuff) at a total depth of 2,109 m. A nonwelded tuffaceous interval above the welded zone, between depths of $\sim 838 \mathrm{~m}$ and $\sim 700 \mathrm{~m}$, carries abundant quartz and sanidine and could be either reworked Bishop Tuff, nonwelded primary ignimbrite, or both. Above a well depth of $\sim 700 \mathrm{~m}$, nearly all the post-Bishop "tuffs" described in cuttings (Fournier, 1989) are crystal-poor and thus most likely to have been eroded from the early rhyolite $(\sim 750-640 \mathrm{ka})$. Although rare layers contain pumice granules, few are likely to be primary pyroclastic deposits. Numerous sandstone and siltstone intervals alternate with the tuffaceous strata, and chips of granite, quartzite, and hornfels were reported within the "tuffs" at several intervals between $50 \mathrm{~m}$ and $700 \mathrm{~m}$. Diatoms were observed at well depths of 107-116 m. A few thin layers of tuff between $700 \mathrm{~m}$ and $135 \mathrm{~m}$ might be primary early rhyolite ash-flow deposits, 
but we think that most such material is fine-grained ashy sediment reworked from the widespread early rhyolite ash, from nonwelded Bishop Tuff, and from the Glass Mountain pyroclastic apron east of the lake. During the early postcaldera and resurgent intervals, such nonindurated pyroclastic material dominated circumlacustrine surfaces and necessarily dominated the sheetwash, fluvial, and lacustrine sediment budget.

Fournier (1989) summarized her observations on both drillholes, with input from diatom and ostracod specialists and stable-isotope data, to provide a paleoenvironmental interpretation of the lake. Authigenic minerals she identified include zeolites, analcite, K-feldspar, albite, montmorillonite, silica, and widepread calcite, but virtually no evaporites.

Ostracod assemblages (mostly Candona and Limnocythere) from the lower half of the 305-m CH-1 core suggested wide fluctuations in lakewater salinity, with slightly (2-3 parts per thousand, ppt) and moderately (3-10 ppt) saline intervals alternating with a few strongly (10-35 ppt TDS) saline ones. (Seawater contains $\sim 35 \mathrm{ppt}$; the present-day Owens River has $\sim 0.2$ ppt [200 parts per million, ppm]; and rainwater $\sim 20 \mathrm{ppm}$.) The most saline conditions were found at core depths of 305-295, 278, and 191-178 m. Dessication cracks and cross bedding in the lowest $\sim 15 \mathrm{~m}$ of the core indicate very shallow water. In the middle part of the core, ostracods at core depths of 186,178 , and $166 \mathrm{~m}$ suggested a lake only $3-5 \mathrm{~m}$ deep. Above a core depth of $\sim 150 \mathrm{~m}$, however, both ostracods and diatoms were interpreted to signify deeper and fresher water, with an open-water lake typically $\sim 15 \mathrm{~m}$ deep and sometimes as deep as $50 \mathrm{~m}$, before later shallowing to 5-10 m. Higher in the core at 100-110 m, both diatoms and ostracods suggested fresher water (1-3 ppt), and above well depths of $\sim 69 \mathrm{~m}$ littoral sandstone and conglomerate predominate. The planktic freshwater diatom Stephanodiscus dominated assemblages above $150 \mathrm{~m}$ in well CH-1 and was also identified in the cuttings of well 66-29 at well depths of $107-116 \mathrm{~m}$. Lakewater $\mathrm{pH}$ was inferred to fluctuate in the range 8-11. Scarcity or absence of diatoms (which dissolve at $\mathrm{pH} \geq 9$ ) below well depths of $135 \mathrm{~m}$ in well 66-29 and $166 \mathrm{~m}$ in well CH-1 are consistent with moderately (though seldom strongly) saline-alkaline conditions, followed by fresher water (1-5 ppt) during roughly the last quarter of the lake's existence.

\section{Filling History of the Lake}

The lake-filling sequence appears to represent at least 600,000 years of sedimentation. Iceberg-rafted Sierran erratics were dropped on early rhyolite lavas as old as $700 \mathrm{ka}$ and later lifted by intracaldera resurgence to elevations hundreds of meters above any undeformed shoreline. In well $\mathrm{CH}-1$ pumice granules containing hornblende and biotite were reported in sandy sediments at a depth of 185-190 m (Lewis, 1975), and in well 66-29, Fournier reported hornblende and biotite in ashy sediments at depths of $97-116 \mathrm{~m}$ and $390-400 \mathrm{~m}$. As hornblende is absent in early rhyolite, Bishop Tuff, and Glass Mountain rhyolites but abundant in several moat rhyolites, such sedimentary intervals may record the widely spaced eruptive episodes at 570-500 ka and 362-329 ka that produced, respectively, the hornblende-biotite rhyolites of the northcentral chain and the southeast moat cluster (Bailey, 1989; Hildreth, 2004).

Near the central part of the former lake basin, the wellhead for 66-29 is at an elevation of 2,125 m, and the base of the sediment column (which rests on the Bishop Tuff) is at $1,429 \mathrm{~m}$ asl. The latter is equivalent in elevation to the floor of Owens Gorge $\sim 22 \mathrm{~km}$ downstream from Long Valley Dam and is $729 \mathrm{~m}$ lower than the highstand shoreline gravels $(2,158 \mathrm{~m})$ at the lake's outlet arm. In considering how and when the lake eventually drained, it needs to be kept in mind that postcaldera Long Valley was a profound depression and that it took more than half a million years of sedimentation to raise lake level to its threshold for overflow.

For most of its lacustrine lifetime, Long Valley Lake had no outlet. It accumulated runoff from most of its periphery, including the highlands of Glass Mountain, Bald Mountain, and the Sierra Nevada. Groundwater loss may have been limited until lake level approached the threshold of overflow where fracture-dominated seepage could take place southeastward through the Bishop Tuff and eastward through granodiorite toward Chidago Canyon. Calcite is common (and aragonite rare) as an interstitial precipitate in the lake sediments, but evaporites are absent. Fracture-filling films of gypsum and rare disseminated grains were identified (only by x-ray diffraction analysis), usually associated with trace pyrite, at depths of 105-125 m and 273-296 m in well CH-1, but none was found in well 66-29. Despite presumed hydrothermal fluid input and the ubiquity of rhyolite tuffs, no borates or Li salts were identified, although Li contents of 37-660 ppm were reported in clay-rich silts (table 6 of Fournier, 1989). Failure of closed-basin lake water to saturate with borates, gypsum, gaylussite, trona, or halite for half a million years indicates that precipitation, runoff, and groundwater influx usually matched or exceeded losses by evaporation and seepage, although the sandy and saline intervals identified in the cores do suggest periods of shallowing. The apparent rarity of dessication may reflect the position of Long Valley adjacent to the regionally lowest segment of the Sierran rangecrest, a location that reduces the rain-shadow effect of the mountain range. The lake's elevation, greater than that of most Great Basin lakes, may also have had a role in limiting evaporation. Even under relatively arid conditions today, losses by evaporation and evapotranspiration amount to only $\sim 13$ percent of the annual runoff into Long Valley (Sorey and others, 1978).

A closed basin with moderately steep slopes might be expected to have recorded lake-level fluctuations that responded to Pleistocene climatic variations. Well CH-1, which was drilled into the gravelly littoral apron $3 \mathrm{~km}$ east of the lake's western highstand (fig. 5), passed from silicacemented sandstone and conglomerate into lacustrine silts at a depth of $69 \mathrm{~m}$. Although fine sand, silt, and clay dominate the rest of the core to its total depth of $305 \mathrm{~m}$ (Lewis, 1975), lenses of sand and gravel are intercalated with the fines within 
core depth intervals of 125-160, 170-180, and 206-214 m. Mostly reported as components of graded beds, such gravels may reflect sublacustrine gravity flows from the nearby Hot Creek delta rather than lake contractions. Well 66-29, closer to the center of the lake basin, penetrated $\sim 700 \mathrm{~m}$ of lake sediments, but no gravel or coarse sand was found below a depth of $135 \mathrm{~m}$ (Fournier, 1989). In neither well was any unconformity or paleosol reported. There is thus no robust record of episodic contractions at Long Valley Lake that might correspond to interpluvial warm-dry intervals. The only real evidence for lake-level fluctuation is the crossbedded sand, wavy bedding, and inferred high salinity in the bottom $15 \mathrm{~m}$ of the $\mathrm{CH}-1$ core. Mudcracks were also reported at depths of $275-292 \mathrm{~m}$ in the $305-\mathrm{m}$ core but not at any shallower level.

The broad, flat floor of the caldera lake, its extended filling history, its proximity to the Sierra Nevada, and a high sedimentation rate (especially in early postcaldera time) may have rendered its level an insensitive recorder of climate changes. The drillhole evidence is, in any case, inadequate to assess climate-related fluctuations with any confidence; well CH-1 is littoral and not deep enough and well 66-29 produced only cuttings.

Unlike Owens Lake, which alternately closed and overflowed in response to Pleistocene climate fluctuations (Smith and Bischoff, 1997), Long Valley Lake may simply have progressively filled the deep caldera depression with sediment at climatically varying rates. Lake water may have remained fairly shallow $(<15 \mathrm{~m})$ most of the time, as suggested by the ostracod and diatom evidence, though it may sometimes have been as deep as $50 \mathrm{~m}$ or more, while sedimentation ultimately raised lake level to its threshold and only then initiated incision of the outlet gorge that drained it.

The $700 \mathrm{~m}$ of sediment that overlies the 767-ka Bishop Tuff in well 66-29 yields an average sedimentation rate of $\sim 1.1 \mathrm{~mm} / \mathrm{yr}$ if lake deposition ended at $\sim 150 \mathrm{ka}$ (or $1.25 \mathrm{~mm} / \mathrm{yr}$ if it had ended at $\sim 200 \mathrm{ka}$ ). For comparison, elsewhere in the Owens River system, long-term average sedimentation rates were $0.54 \mathrm{~mm} / \mathrm{yr}$ since the Bishop Tuff at Mono Lake; $0.4 \mathrm{~mm} / \mathrm{yr}$ since the Bishop Tuff in Owens Lake; and $0.24 \mathrm{~mm} / \mathrm{yr}$ since the Matuyama-Brunhes reversal at Searles Lake (Scholl and others, 1967; Sarna-Wojcicki and others, 1997; Liddicoat and others, 1980). The greater rate at Long Valley Lake reflects rapid proximal redeposition of loose rhyolitic ash, strictly closed-basin sedimentation, and near-absence of dessication intervals.

Early postcaldera margins of the lake basin, now concealed by hundreds of meters of sediment, are likely to have included avalanche deposits, talus cones, fan deltas, and debris-flow deposits that issued from initially steep caldera walls. Such deposits were described in detail for Crater Lake caldera, Oregon (Bacon and others, 2002). No such deposits are known to have reached the middle of the lake, where the lower $\sim 400 \mathrm{~m}$ of the $700 \mathrm{~m}$ of sediment in Republic well 66-29 consists of fine- to medium-grained siltstone and sandstone. Distal facies of turbidites were probably not distinguishable in well cuttings.

In early postcaldera time, subaerial erosion of the nonindurated pyroclastic apron of Glass Mountain had produced a few deep arroyos that drained to the lake until its level eventually rose high enough to drown them. Deposits of lacustrine sandstone preserved near the floor of Watterson Canyon at 2,145 m asl (UTM 501/6735) lie $\sim 50 \mathrm{~m}$ below the arroyo rim and $135 \mathrm{~m}$ lower than the nearby highstand shoreline. Similarly, sandstone near the mouth of the Watterson Troughs arroyo (UTM 509/700) at $\sim 2,201 \mathrm{~m}$ asl is $\sim 30 \mathrm{~m}$ below the local rim and $80 \mathrm{~m}$ lower than the high strandline. Between them, a third arroyo (UTM 518/682; $1.2 \mathrm{~km}$ north of Watterson Canyon highway) exposes sandstone at 2,225 $\mathrm{m}$, well below the adjacent shingle-capped mesa 2274. Only the uphill reaches of these and other pre-highstand arroyos are still exposed because their medial and distal reaches were subsequently filled and concealed by sediment of the rising lake and by post-lake alluvium. Survival of such sandstone-floored pre-highstand arroyos preserves evidence of the radial drainage into the deep caldera depression early in the lake's history. Because these three and a few other sharp ephemeral arroyos were cut in loose pyroclastics and head near the east rim of the basin, while having only small upstream catchment areas, they had probably grown eastward and deepened largely by headward erosion.

The youngest lake sediments, where best exposed (10-25 $\mathrm{m}$ thick) along the west side of the basin, are of two contrasting facies - littoral sands and gravels that overlie lake-floor silt and mud. The exposed contact of the former atop the latter is generally sharp and descends from a western elevation as high as 2,160 m north of Hot Creek to as low as $\sim 2,090 \mathrm{~m}$ near Little Alkali Lake, $\sim 5 \mathrm{~km}$ farther east. The $0.7^{\circ}$ eastward slope of the contact reflects progradation and upward coarsening as the lake level declined during its terminal phase.

Along the east side of the former lake basin, however, the contact of littoral sands and gravels atop the central siltstones is rarely exposed, owing to extensive post-lake alluvial fans. The only exception crops out along the southeast side of present-day Lake Crowley, where a wave-cut bluff extends $\sim 1 \mathrm{~km}$ northward from the mouth of the modern outlet arm. Along this bluff (UTM 473/615), $20 \mathrm{~m}$ of sediments were deposited on a wave-planed extracaldera surface of Bishop Tuff late in the lake-filling history, as the lake approached its threshold but before it overflowed. At elevations of 2,065-2,070 $\mathrm{m}$ ( $\sim 80 \mathrm{~m}$ lower than the high strandline nearby), $\sim 4 \mathrm{~m}$ of crudely bedded fuvial conglomerate was deposited directly on the smoothly eroded ignimbrite surface, which there slopes lakeward at $\sim 4^{\circ}$. The indurated fluvial gravels consist of well-rounded pebbles, mostly $1-10$ $\mathrm{cm}$, exclusively of granitic and metasedimentary lithologies; they include no clasts of rhyolite, thus indicating Sierran sources from nearby Whisky, Hilton, or McGee Creeks (fig. 5), not from Long Valley or Owens River. Atop the fluvial 
conglomerate is laminated lake silt, pumice-bearing and 2-8 m thick, which is overlain by several meters of rhyolite-dominant littoral sandstone and conglomerate that contains only 10-30 percent basement clasts and grades up into a surface sheet of loose gravel that extends $\sim 2 \mathrm{~km}$ northeast, up the gently bevelled wave-planed terrace of Bishop Tuff to the high strandline at 2,150 $\mathrm{m}$. These exposures are significant because they record the transition, near the subsequent outlet, from a closed lake fed by Sierran streams to a nearly full lake that invaded what became its outlet arm, mobilized Glass Mountain pyroclasts along its east shore, and approached its ultimate highstand, from which it soon spilled into Owens Gorge.

Long Valley Lake was extraordinary in several ways, especially the great initial depth of the basin and its catastrophically abrupt origin, where no lake had been before. Most of its littoral deposits are quite coarse, dominated by pebbles and cobbles. Plane-laminated sandstone with smaller pebbles crops out widely on the west side and sparsely downslope on the east side at limited exposures of shoreface deposits, which are largely covered by post-lake alluvium. Coarseness of beach gravels apparently reflects short transport distances and resistance of the dominant rhyolite clasts to disintegration. The lake was fairly saline (though not evaporite-depositing) early in its history but changed with time to slightly saline and finally fresh. Although it remained a closed basin until close to extinction, the lake always received very fresh streamflow from the Sierra Nevada and fresh groundwater inflow from coarse alluvial fans. Lakefloor seepage loss was probably small until the lake approached its spillpoint.

\section{Owens River Gorge}

\section{Physiography, Lithology, and Tectonics}

The sinuous course of Owens Gorge winds $\sim 30 \mathrm{~km}$ from Long Valley Dam to the gorge mouth at Pleasant Valley (figs. 1-3) where the Owens River turns eastward along the toe of the eroded scarp called Chalk Bluff, which terminates the Volcanic Tableland. Everywhere in the gorge, precipitous walls 100-200 m high rise above a flat floor 30-70 m wide, along which today's controlled creek meanders. The sinuosity of the gorge as a whole suggests antecedence of a meandering stream across a formerly lower-relief surface and its progressive entrenchment as Owens Valley subsided and the Volcanic Tableland tilted southward. Among numerous tight turns of the gorge is a hairpin bend at kilometer 20 (downstream from the dam; fig. 3) that has an amplitude of $500 \mathrm{~m}$. A big Z-bend only $1.5-2.5 \mathrm{~km}$ downstream from the dam seems particularly anomalous, especially as it begins adjacent to the highstand lake terrace and is not fault-controlled. Downstream from this bend is the straightest reach of the entire gorge, here trending due east from kilometer 2.5 to 6 (figs. $3,5,11$ ). The gorge resumes sinuosity from kilometer 6 to 11 as it crosses the basement ridge, and it makes large changes in gross trend at kilometers 8.2, 9.4, and 14.2. From kilometer 3 to 13 , where the gorge trends east or southeast, its north rim is $10-20 \mathrm{~m}$ higher than its south rim, reflecting the tectonic tilt manifest in the warped highstand shoreline.

Although remaining sinuous in detail, the gross trend of the gorge is $170^{\circ}$ from kilometer 14 to 24 , where it then bends around to southwesterly until it joins Rock Creek at kilometer 25.5 (Birchim Canyon). The final reach, from the confluence to the gorge mouth (kilometers 25.5-31), although still sinuous, grossly trends $125^{\circ}$ (fig. 3).

\section{Gradients Along Owens River Gorge}

No shoreline gravels or other lake features have been found, despite repeated search, more than $2.4 \mathrm{~km}$ east of the dam along either side of Owens Gorge. Along the north rim of the gorge for $2.4 \mathrm{~km}$ downstream from the dam, wellrounded lacustrine gravels (and patches of indurated sandstone and pebble conglomerate) are preserved at elevations as high as $2,158 \mathrm{~m}$. South of the outlet arm, such gravels drop to a sharply defined strandline only as high as $2,100 \mathrm{~m}$, owing to regional southward downwarping (toward the Round Valley rangefront fault) that has continued since extinction of the Pleistocene lake. Pleistocene shoreline deposits also extend beneath Lake Crowley reservoir, which dates from 1941 and has a normal pool level of 2,062 m. Most of $21-\mathrm{km}^{2}$ Lake Crowley is shallower than $15 \mathrm{~m}$, and it only deepens to $\sim 20 \mathrm{~m}$ within $2-3 \mathrm{~km}$ of the dam, along the former stream channel drowned by the outlet arm.

A 1937 topographic survey (City of Los Angeles, 1937) shows the river channel that was later drowned by Lake Crowley (ignoring the stream's intrachannel meanders) to have had an average gradient of $2.8 \mathrm{~m} / \mathrm{km}$ for the $8-\mathrm{km}$ reach from the head of the modern reservoir to the confluence of Convict Creek. From there to the dam, the gradient lessened to $1.8 \mathrm{~m} / \mathrm{km}$ for $3 \mathrm{~km}$, and it remained even gentler along the outlet arm for $2 \mathrm{~km}$ downstream from the dam.

A linearized profile of Owens Gorge (fig. 13) was constructed from 1:24,000 USGS topographic maps. The stream gradient increases to $\sim 4 \mathrm{~m} / \mathrm{km}$ from the Z-bend to the first granodiorite exposure in the riverbed $5 \mathrm{~km}$ below the dam. From there, the river's eastward course runs largely on granodiorite, and its gradient steepens to $14.6 \mathrm{~m} / \mathrm{km}$ as far as the sharp south bend at kilometer 8.2 (figs. 3, 11). The 2-kmlong south-flowing reach is cut through a narrow granodiorite gorge that is widely draped by Pliocene basalt, but it retains a similar gradient of $\sim 13.8 \mathrm{~m} / \mathrm{km}$ as far as kilometer 10 . There, a steep pitch of the granodiorite floor (fig. 13) drops $40 \mathrm{~m}$ along a $600-\mathrm{m}$-long reach $(67 \mathrm{~m} / \mathrm{km})$. This may be a Pliocene knickpoint, the upstream advance of which was stalled by emplacement of the 3.3-Ma basalt. For the next $2.7-\mathrm{km}$ reach, the gradient remains fairly steep $(\sim 30 \mathrm{~m} / \mathrm{km})$ until the granodiorite finally drops below stream level at kilometer 13 , just downstream from power house \#1. For the remaining $20 \mathrm{~km}$, 


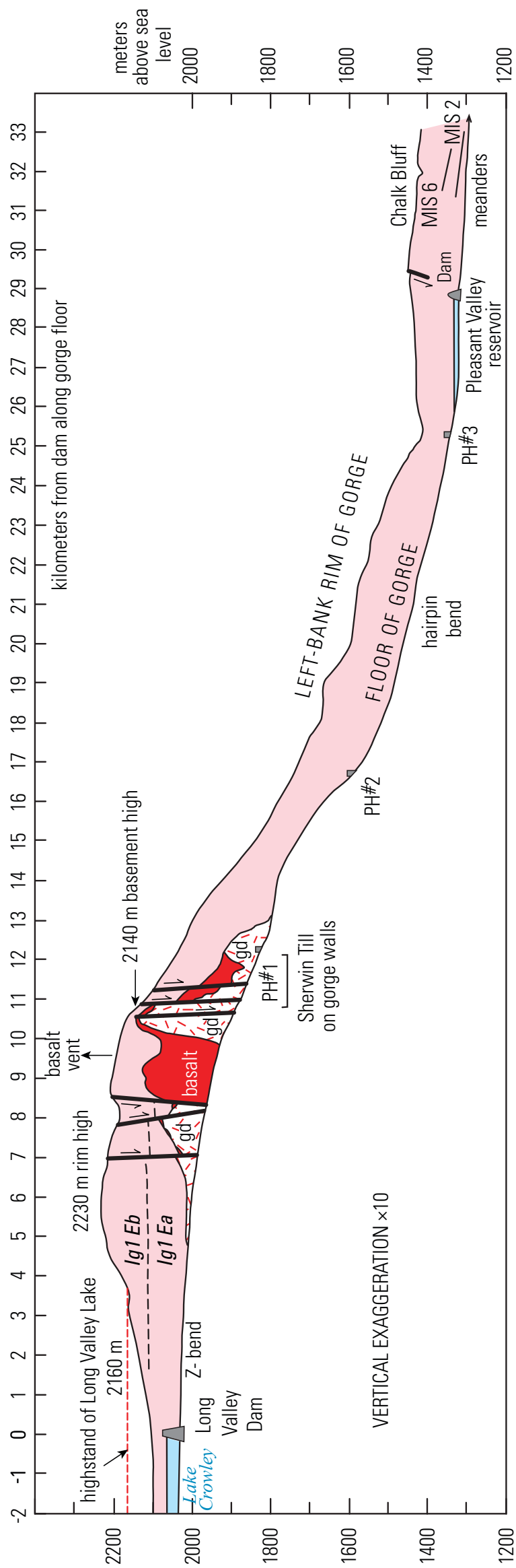

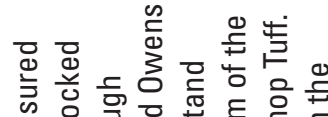

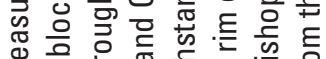

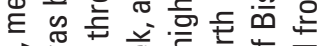
ह

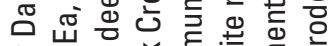

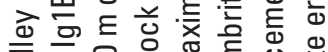

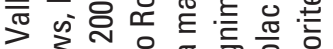

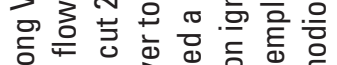

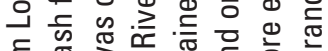
중

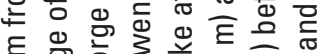

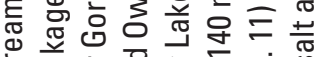

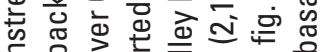

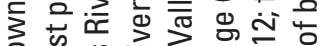
흠. 의

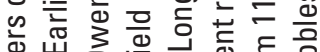
ه 응 흔

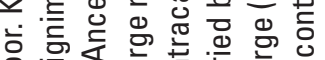

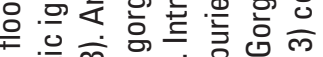

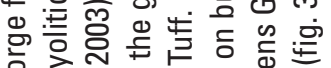

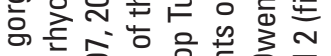

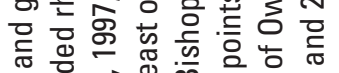

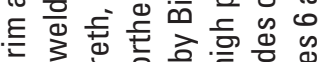

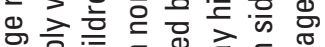

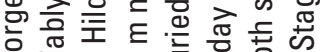

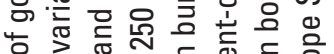

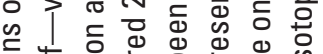

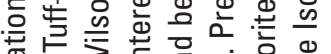

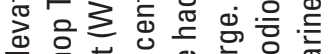

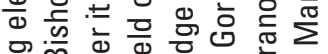
可

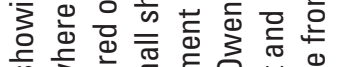

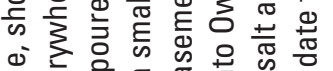
बi वे d

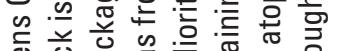
递苍要

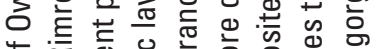

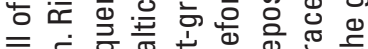

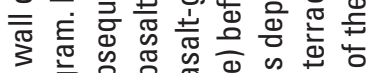

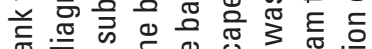

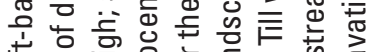

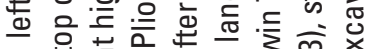

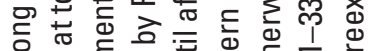

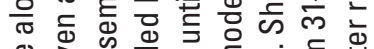

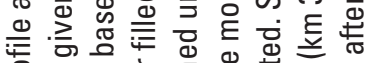
흠

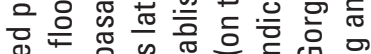
N

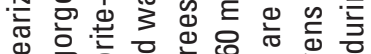

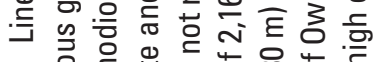

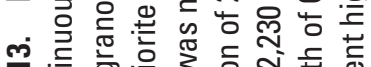
닝

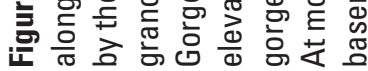




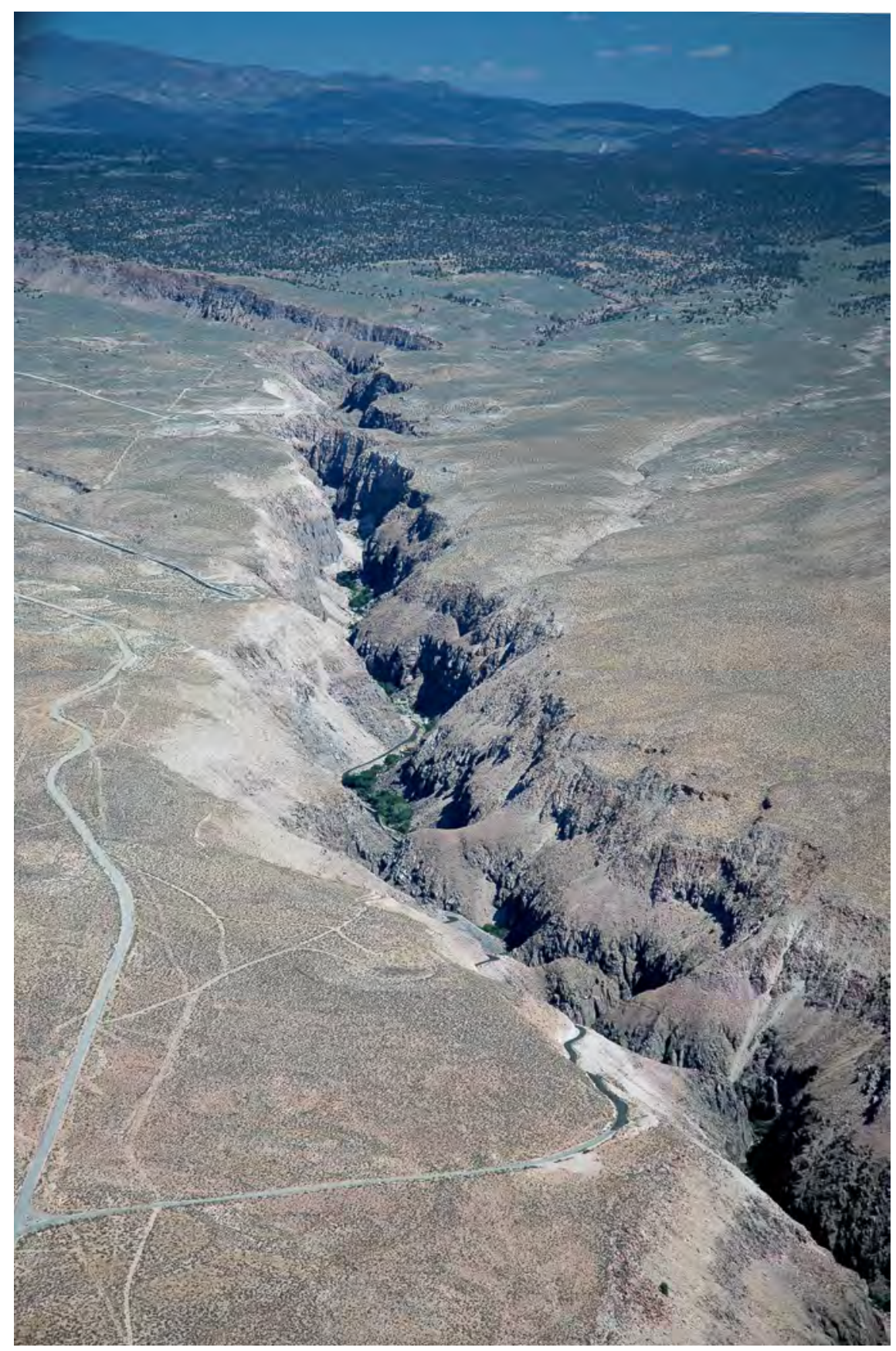

Figure 14. Middle reaches of Owens River Gorge, 150-200 m deep, viewed northward. The sharp upstream bend from southeasterly $\left(\sim 130^{\circ}\right)$ to southerly $\left(\sim 170^{\circ}\right)$ trend is near kilometer 14 (fig. 3). Upstream reach exposes granodiorite-basalt basement high; downstream reach in foreground is cut exclusively in Bishop Tuff. Note sinuous course of gorge floor, walled by densely welded ignimbrite. Road in foreground descends from gorge rim to power house \#2. White roadcut on rim $\sim 4 \mathrm{~km}$ upstream marks similar road that descends to power house \#1. Also note ecological transition at elevation $\sim 2,000 \mathrm{~m}$ from arid Volcanic Tableland to moister pine-forest upland that surrounds the divide (figs. 3,11 ) that separates Long Valley and Owens Valley watersheds. Modern annual precipitation near the divide can be twice the annual mean at Bishop Airport (173 mm/yr) near the foot of the Volcanic Tableland. Aerial oblique photo courtesy of Allen Glazner.

as far as Chalk Bluff, the gorge is walled and floored entirely by the Bishop Tuff (fig. 14).

Downstream from the limit of granodiorite exposure, the gradient is $15.4 \mathrm{~m} / \mathrm{km}$ for the initial $1.3-\mathrm{km}$ reach floored by ignimbrite, increasing to $36.5 \mathrm{~m} / \mathrm{km}$ for the next $1.1 \mathrm{~km}$, and then steepening sharply to $70 \mathrm{~m} / \mathrm{km}$ for the $2.3-\mathrm{km}$ reach that extends to kilometer 16.8, just below power house \#2 (figs. 13, 14). This may represent an active modern knickpoint, still advancing headward in response to southward tilting of the Volcanic Tableland.

The gradient of the reach from kilometer 16.8 to 18.6 lessens to $37.5 \mathrm{~m} / \mathrm{km}$, then for a $6.2-\mathrm{km}$-long reach that includes a large entrenched meander, it further lessens to $\sim 17 \mathrm{~m} / \mathrm{km}$ as far as kilometer 24.8 . From power house \#3 at the confluence of Rock Creek, the gradient is only $9.5 \mathrm{~m} / \mathrm{km}$ as far as the head of Pleasant Valley Reservoir, and beneath the 3-km-long drowned reach of the reservoir the gradient is only $4 \mathrm{~m} / \mathrm{km}$. Along Pleasant Valley at the gorge mouth, the gradient is $\sim 6 \mathrm{~m} / \mathrm{km}$. The Owens River then turns eastward along the foot of Chalk Bluff, where the riverbed (ignoring the stream's many tight meanders) has a gradient of $\sim 4.8 \mathrm{~m} / \mathrm{km}$ for the $8.5-\mathrm{km}$ reach ending at Five Bridges (fig. 3).

Measured linearly, ignoring the sinuous course of the gorge (fig. 14), the average gradient is $\sim 6 \mathrm{~m} / \mathrm{km}$ from the base of Long Valley Dam to the upstream end of the granodiorite window, $\sim 25 \mathrm{~m} / \mathrm{km}$ for the reach through the window itself, and $38 \mathrm{~m} / \mathrm{km}$ from there to the Rock Creek confluence. The average gradient is thus gentlest near the lake outlet where 
the gorge is cut in the Bishop Tuff upstream from the basement high, steeper where cut through the granodiorite-basalt paleoridge, and steepest of all where cut exclusively in the Bishop Tuff farther downstream (figs. 13, 14).

\section{Drainage Divide Incised by Owens River Gorge}

The dissected surface of the ignimbrite includes a broad low-relief divide that trends northward across the upper Volcanic Tableland (figs. 3, 5, 11, 13), from Owens River Gorge past Round Mountain to Watterson Canyon. The divide separates dry arroyos that trend westward toward Long Valley from those that trend southeastward toward Owens Valley. The highest reach of the Owens River Gorge rim is 5-6 km downstream from the dam at an elevation of 2,230 m (figs. 3, 11, 13), $230 \mathrm{~m}$ above the adjacent gorge floor, $105 \mathrm{~m}$ lower than the highest reach of the warped Pleistocene shoreline near Wilfred Canyon, but 70-80 $\mathrm{m}$ higher than the 2,1502,158-m shoreline near the upper end of the gorge. The gorge rim consists everywhere of Bishop Tuff. From the 2,230-m high point, the north rim remains higher than $2,160 \mathrm{~m}$ for an additional $5 \mathrm{~km}$ downstream, for a total distance of $11 \mathrm{~km}$ from the dam. How could the Owens River have cut through an 11-km-wide barrier that stood as much as $70-80 \mathrm{~m}$ above the nearby highstand of the lake that fed it?

Much of the gorge-rim high overlaps the north-south basement paleoridge exposed on the gorge walls, atop which the Bishop Tuff is less than half as thick as it is just upstream and downstream of the high. It was suggested by Rinehart and Ross (1957) and Putnam (1960) that the high represents an "arch," implying that the ignimbrite surface of the Volcanic Tableland had been folded upward to create a modest divide that impounded Long Valley. We reject this idea because the Bishop Tuff has not been folded there. The earliest ignimbrite package (Ig1Ea; as thick as $80 \mathrm{~m}$ ) banked against the basement paleoridge (fig. 13), and the following packages (Ig1Eb, Ig2) surmounted it, draping it and successively offlapping for $25-55 \mathrm{~km}$ farther southeastward (Wilson and Hildreth, 1997, 2003). The Ig1Ea/Ig1Eb contact west of the basement ridge, as seen on the east-west trending canyon wall, is planar and subhorizontal, not arched or folded. Moreover, the south-trending axis of the purported arch would run parallel, not perpendicular, to the southward tilt of the landscape manifested by the highstand shoreline. Both internal stratigraphic contacts and welding zonation (figs. 5, 11 of Wilson and Hildreth, 2003) reflect draping of the Bishop Tuff over the granodiorite-basalt high, not tectonic folding. The north-south paleoridge, essentially perpendicular to the upstream course of Owens Gorge, existed there before eruption of the 3.3-Ma basalt, thus long before emplacement of the Bishop Tuff and long before draining of Long Valley Lake.

For most of its lifetime, Long Valley Lake was confined by the caldera depression, which was initially at least $700 \mathrm{~m}$ deeper than its outlet threshold. Late in its existence, when the lake approached its threshold for overflow, the basement paleoridge and its draping ignimbrite provided the final barrier. Regional tectonic movements did not restrain overflow by arching but actually promoted overflow by southward downwarping of the outlet.

\section{Southward Tilting of Volcanic Tableland}

There is no doubt that the Volcanic Tableland was tilted southward toward Owens Valley after emplacement of the Bishop Tuff. Steepening of the ignimbrite surface was a key factor in converting a shallow meandering stream into a 200-m-deep gorge. The present-day elevation difference down the Bishop Tuff surface, from the draped basement high to the Chalk Bluffs scarp north of Bishop, is $\sim 900 \mathrm{~m}$, an average gradient of $\sim 2^{\circ}$. This is divisible into an upper plateau that slopes only $1.5^{\circ}-2^{\circ}$, a short middle segment descending from the basement high that slopes $4^{\circ}-6^{\circ}$, and the distal Volcanic Tableland, which slopes $3^{\circ}-4^{\circ} \mathrm{SSW}$. toward Round Valley and $1^{\circ}-1.5^{\circ}$ SE. toward Bishop (figs. 2, 3). Poorly constrained, however, are what fraction of the gradient existed at the time of eruption and how much has been added by tectonic tilting in the past 767 k.y. Subsidence of northern Owens Valley was underway by the late Pliocene (Bachman, 1978; Lueddecke and others, 1998; Phillips, 2008), probably starting soon after 3.4 Ma (Phillips and Majkowski, 2011), so a significant fraction of the tilting of the basement beneath the Tableland is likely to have preceded the great eruption. Investigators have addressed the many north-trending extensional faults cutting the Volcanic Tableland and the downwarping of its east and west flanks toward Fish Slough and Round Valley (Bateman, 1965; Dawers and others, 1993; Pinter, 1995; Ferrill and others, 1999), but we know of no published attempt to estimate the southward (south to southeast) postcaldera tilting of the aggregate Volcanic Tableland plateau.

On the basis of well data, the subsurface base of the Bishop Tuff near the town of Bishop has been plotted by Bateman (1965) and by Phillips and Majkowski (2011). Between Chalk Bluffs ( $\sim 3 \mathrm{~km}$ west of Fish Slough where the base of the Bishop Tuff is exposed) and a water well $14 \mathrm{~km}$ southeast (Bateman, 1965, p. 152-154; plate 7), the base drops $294 \mathrm{~m}$ (a slope of $1.2^{\circ}$ ). Over the same reach, the present floodplain of Owens Valley drops $75 \mathrm{~m}$ (a slope of $0.3^{\circ}$ ). If the valley's alluvial floor had a similar slope at $767 \mathrm{ka}$, then the base of the Bishop Tuff beneath northern Owens Valley has been tilted southeast by $\sim 0.9^{\circ}$, similar (probably fortuitously) to the southward tilt imposed on the highstand shoreline of Long Valley Lake in a much shorter time interval.

The lower half of the Volcanic Tableland, well south of the topography-draping influences of the granodiorite paleoridge and the granitoid outcrops of Casa Diablo Mountain (fig. 3; Rinehart and Ross, 1957; Bateman, 1965), slopes on average $\sim 1.4^{\circ}$ southeast toward Bishop. However, tens of meters of poorly welded ignimbrite have been eroded from the surface of the Volcanic Tableland, muddling estimates of its original slope; and southward thickening of the ignimbrite under much of the Volcanic Tableland requires its base 
to slope more steeply than its surface. Nonetheless, it seems safe to infer that about half $\left(0.9^{\circ}\right)$ of the distal slope $\left(\sim 1.4-2^{\circ}\right)$ reflects post-eruptive tilting of the Bishop Tuff. Into this gently sloping ignimbrite surface the distal half of Owens Gorge has been incised (figs. 2, 14). The upstream half of the gorge, cut through granite and basalt in addition to the Bishop Tuff, has a more complex incision history.

\section{Sherwin Glacial Deposits in Owens River Gorge}

Sherwin Till, a major early Pleistocene glacial deposit, is well exposed east of the mouth of Rock Creek canyon (Blackwelder, 1931). The sheet is as thick as $200 \mathrm{~m}$ and extends farther out from the rangefront than till of any subsequent glacial advance in the eastern Sierra Nevada (figs. 11, 15A). A long history of erosion has destroyed primary morainal landforms and reduced the deposit to a rolling hill-and-gully terrain. Gilbert (1938) reported that Sherwin Till underlies the Bishop Tuff on the walls of Owens Gorge, and Putnam (1960) mapped till outcrops atop the basement paleoridge on both walls of the gorge. If the gorge existed at the time of the Sherwin glaciation (MIS 22; 900-866 ka), how did Sherwin deposits reach its northeast side? Gilbert, Putnam, and Rinehart and Ross (1957) interpreted mediocre exposures of gorge-wall drift as till, Sharp (1968) considered at least some of them to be Sherwin outwash, and we are convinced that both till and outwash are present-mostly till (compare figs. 16, 18).

Just upstream of power house \#1, Sherwin deposits 20-35 m thick crop out between Pliocene basalt and Bishop Tuff for $\sim 1.5 \mathrm{~km}$ along both walls (figs. 15A, 16). On Putnam's (1960) profile along the LADWP tunnel (just southwest of the gorge), Sherwin deposits are nearly continuous and as thick as $135 \mathrm{~m}$ (fig. 6). In test hole 1-C, along the tunnel alignment only $350 \mathrm{~m}$ from the gorge rim, the till is $85 \mathrm{~m}$ thick, sandwiched between basalt and $\sim 35 \mathrm{~m}$ of overlying Bishop Tuff (Putnam, 1960). The base of the thick Sherwin deposit in test hole 1-C has an elevation of 2,010 m, barely higher than its exposed base $(2,005 \mathrm{~m})$ on a gorge-wall promontory 700 $\mathrm{m}$ ENE. (UTM 583/571), where it likewise rests on Pliocene basalt.

Surface outcrops of Sherwin Till lie within $50 \mathrm{~m}$ of test hole 1-C (fig. 11), and the sheet of till exposed extends to within $\sim 600 \mathrm{~m}$ of gorge-wall till outcrops overlain by the Bishop Tuff. Near Rock Creek 3-4 km west of Owens Gorge, the exposed till is $\sim 200 \mathrm{~m}$ thick and forms hills that rise as much as $75 \mathrm{~m}$ higher than the Owens Gorge rim (fig. 15A). Sherwin deposits thus thin eastward from $\sim 200 \mathrm{~m}$ near Rock Creek to $85 \mathrm{~m}$ at hole 1-C to only $20-35 \mathrm{~m}$ on the gorge walls. Basal elevation of the till ranges from 1,900-2,000 m along Rock Creek (which preceded the glaciation) to $\sim 2,160 \mathrm{~m}$ atop the granodiorite paleoridge to $2,010 \mathrm{~m}$ at test hole $1-\mathrm{C}$ to $2,005 \mathrm{~m}$ on the gorge-wall promontory and finally as low as $\sim 1,900 \mathrm{~m}$ at its distal downstream outcrop limit on the walls of Owens Gorge above power house \#1 (figs. 11, 15A).
On the southwest wall of the gorge, 1,150 m ESE. of test hole 1-C, we measured a 23-m-thick section of Sherwin drift (between elevations 1,973 $\mathrm{m}$ and 1,950 $\mathrm{m}$ by GPS; UTM 589/568), resting on Pliocene basalt and overlain by $\sim 100 \mathrm{~m}$ of Bishop Tuff (fig. 16). Stones in the till are $\sim 98$ percent granitic and are seriate in size from pebbles to boulders as large as $2.5 \mathrm{~m}$; granitic cobbles and boulders are rounded and many are grussy. Additional sites examined near the upstream (UTM 5835/571) and downstream (UTM 5945/5645) limits of till exposure on the right-bank wall are lithologically similar and range in thickness from 20 to $35 \mathrm{~m}$. No fluvial stratification was observed, but sloughing of the drift and thick colluvium render examination of undisturbed matrix problematic. Nearly all of the subordinate metamorphic stones $(10-50 \mathrm{~cm})$ in the till are blocky and angular, more consistent with till than fluvial outwash.

Sharp (1968) reported one drift site on the gorge walls where he interpreted a sandy silt-poor matrix to be watersorted. We emphasize, however, that the Sherwin Till is derived almost entirely from granitic rocks and that the deposit emerges from a canyon mouth on the granitic rangefront only 5-7 km from Owens Gorge. Till matrix rich in crystal sand is not unexpected for so proximal a granite-derived glacial deposit. Accordingly, we sieved 2-kg samples of unequivocal till matrix (excluding clasts larger than $8 \mathrm{~mm}$, which make up at least half by weight of the bouldery till) from two roadcut exposures of the type Sherwin Till along Rock Creek. Both matrix samples are dominated by sand and granules $(\mathrm{Md}=1.5$ and $1.7 \mathrm{~mm}$, respectively), and both are poor in fines $(0.5$ and 1.7 weight percent finer than $1 / 16 \mathrm{~mm}$ ). We thus think that sandy drift cropping out on the walls of Owens Gorge is mostly till, although one matrix-poor exposure dominated by rounded cobbles is probably outwash. Nonetheless, the outstanding problem remains how outwash streams or Sherwin ice itself could have deposited drift on the far side of Owens Gorge had this reach of the gorge indeed existed in Sherwin time.

The glacier that brought the Sherwin deposits here issued from Rock Creek, a major Sierran canyon. From the canyon's narrow mouth, the ice spread out 5-7 km eastward into a piedmont lobe at least $7 \mathrm{~km}$ wide that banked against and locally overran the north-south granodiorite paleoridge that crosses Owens Gorge (fig. 11). Since Sherwin time, however, normal and dextral displacement on the Round Valley rangefront fault promoted redirection of Rock Creek, which has incised a northeast-trending canyon through a downdropped granitic buttress - from the canyon mouth toward Toms Place. From offset alluvial and colluvial features nearby (undated but probably no older than MIS 6), Phillips and Majkowski (2011) inferred $\sim 150 \mathrm{~m}$ of dextral displacement on the Round Valley Fault. Dextral offset of the apex of Sherwin deposits near the canyon mouth of Rock Creek is at least $500 \mathrm{~m}$, giving an average strike-slip rate of $>0.6 \mathrm{~mm} / \mathrm{yr}$ since MIS 22 (900-866 ka). The piedmont lobe of Sherwin Till (now drained by Whisky, Birch, and Witcher Creeks) was thus displaced and bypassed, while deposition of Tahoe and Tioga (MIS 6 and 2) glacial 


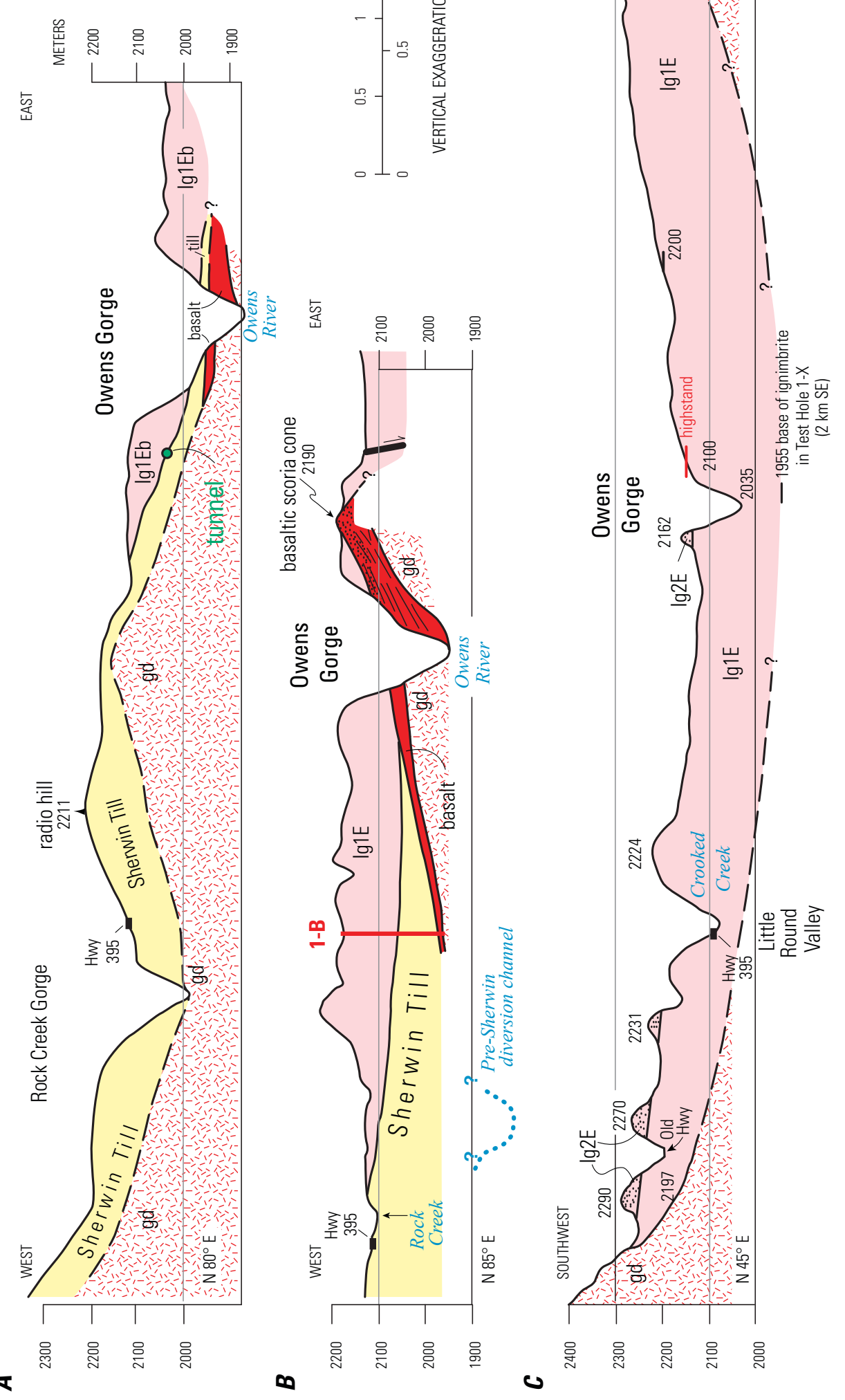

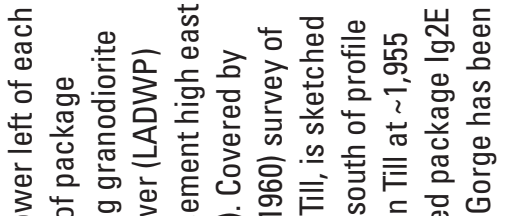

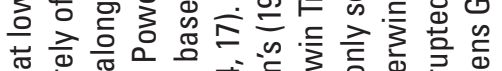

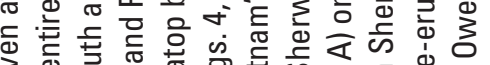

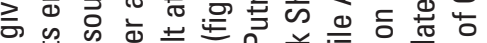

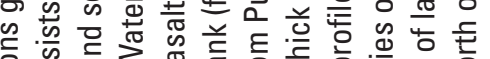

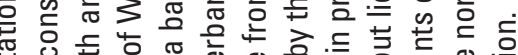

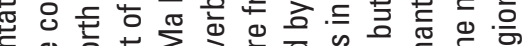

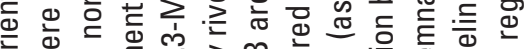

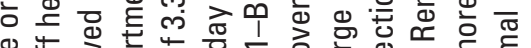

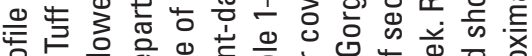
인

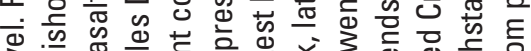

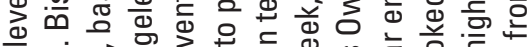

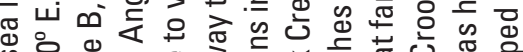

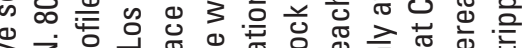

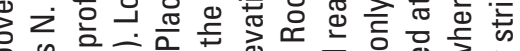
石家.

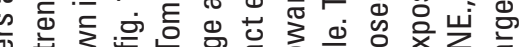

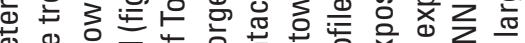

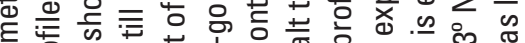
을

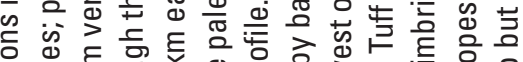

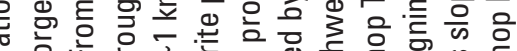

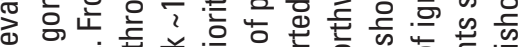

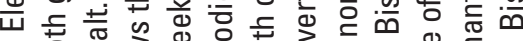

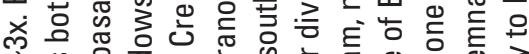
?

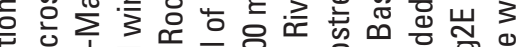

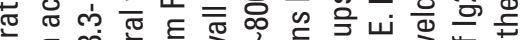

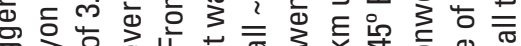

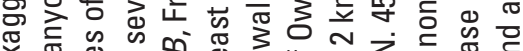
बढ

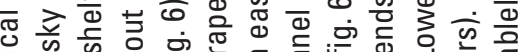

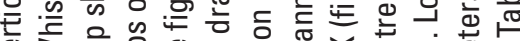
ऽ

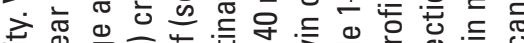

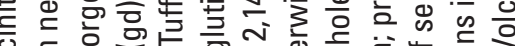

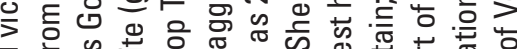

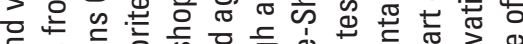

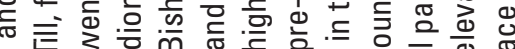

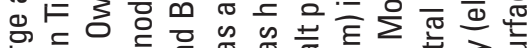

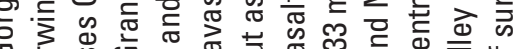

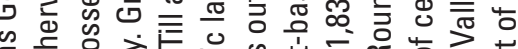

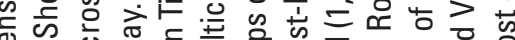

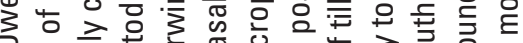

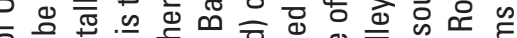

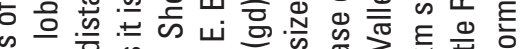

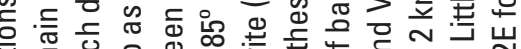

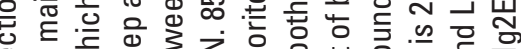

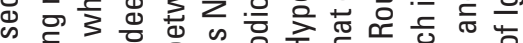

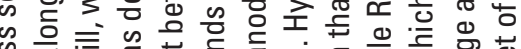

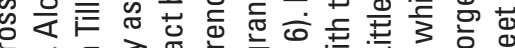

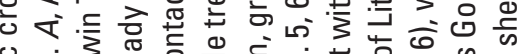

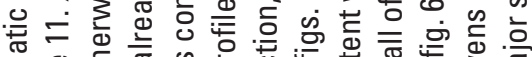

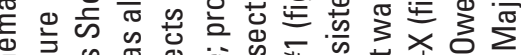

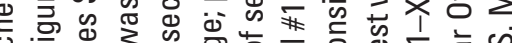

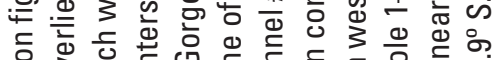

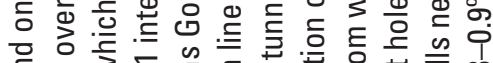

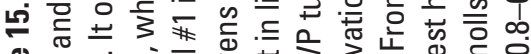

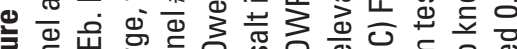

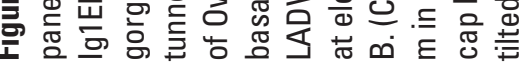




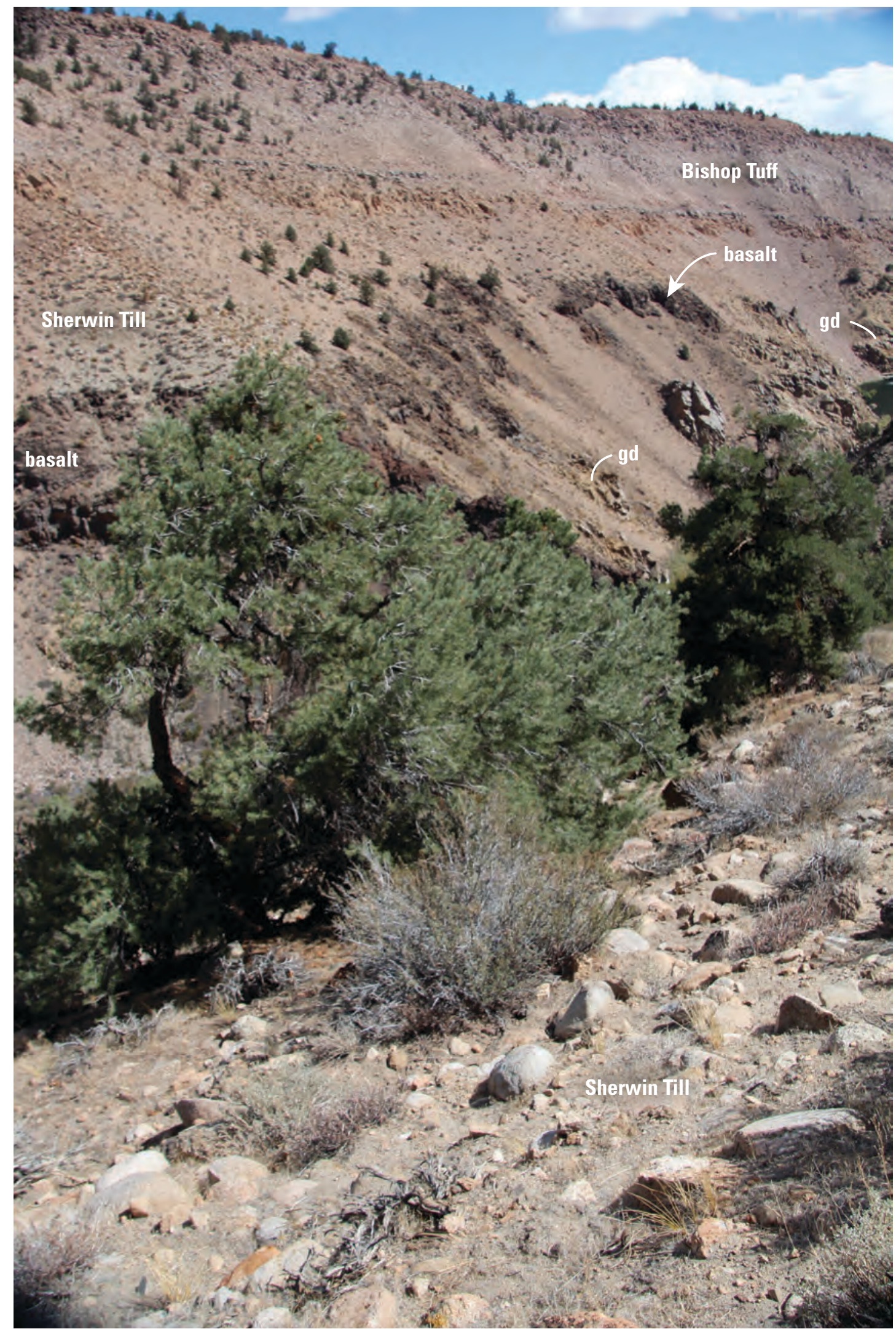

Figure 16. Sherwin Till on both sides of Owens Gorge. Foreground at UTM 589/568, elevation 1,960 m, midway up right-bank wall of gorge; view downstream. Boulder-rich deposit is here $23 \mathrm{~m}$ thick; it consists predominantly of grussy granodiorite stones with ample gritty matrix and overlies Pliocene basaltic lavas. Many boulders are $50-100 \mathrm{~cm}$ in diameter and a few are larger. Same sequence is visible across canyon where bouldery till (best exposed at left) overlies 40-m stack of basalt, which pinches out over 80-m-high cliff of granodiorite (gd) at far right. Till and basalt are overlain by $90-120 \mathrm{~m}$ of welded Bishop Tuff, which extends up to rim. 
deposits was controlled by the new northeasterly drainage toward Toms Place (fig. 11).

Glacial erosion in the Sierra Nevada is likely to have been most profound during the Sherwin glaciation, here presumed to represent MIS 22 and (or) MIS 20. Not only was the Sherwin advance greater than any subsequent glacial advance in the Sierra, but MIS 22 was the first of five great global episodes of ice accumulation (along with MIS 16, 12, 6 and 2) that followed the "Mid-Pleistocene Revolution" (Berger and others, 1993; Muttoni and others, 2003), the transition from higher-frequency lower-amplitude climatic oscillations to lower-frequency higher-amplitude glacio-eustatic fluctuations. In the Sierra Nevada, glacial deposits of MIS 6 and 2 are well preserved, those of MIS 22 scattered and erosively subdued, and those of MIS $16(\sim 630 \mathrm{ka})$ and $12(\sim 410 \mathrm{ka})$ unreported and presumed obliterated during MIS 6.

\section{Alternative Post-Basalt Pre-Sherwin Course of Owens River}

Basaltic lava flows filled the deep granodiorite gorge at 3.3 Ma (figs. 15B, 17). Both the basalt and the Bishop Tuff were reincised to produce the modern gorge sometime after the 767-ka caldera-forming eruption. But where was the local reach of the Owens River between $3.3 \mathrm{Ma}$ and $767 \mathrm{ka}$ ? For $\sim 5 \mathrm{~km}$ along the gorge walls, the Bishop Tuff overlies the Pliocene basalt (or Sherwin drift between them), but nowhere is the Bishop Tuff seen to be inset against a gorge wall of basalt or granodiorite. Although deep reaches of the gorge are cut wholly in ignimbrite both upstream and downstream of the basalt-granodiorite paleoridge, there is no direct evidence that the Bishop Tuff ever filled a precaldera gorge cut into the basalt, nor is there evidence that such a basalt-walled gorge even existed between $3.3 \mathrm{Ma}$ and $767 \mathrm{ka}$. If such a basaltgranodiorite gorge had really existed and was filled by Bishop Tuff at the time of the caldera-forming eruption, the welded ignimbrite had to have been cleanly and completely stripped out of it. In contrast, numerous veneers of rubbly basalt that drape the granodiorite walls of the present-day gorge are preserved from rim to river (figs. 4, 17).

The simplest scenario, that the Owens River Gorge maintained its original course across the basalt-topped granodiorite ridge, is unsustainable. By such a notion, basalt that filled the granodiorite gorge at 3.3 Ma would have been reincised along the same course and such a second-generation gorge would later have been filled with ignimbrite at $767 \mathrm{ka}$. Because block-jointed ignimbrite and rubbly basalt would be more readily eroded than granodiorite, a third-generation gorge would then have been cut through the Bishop Tuff in the middle and late Pleistocene, plausibly along essentially the same course and with little or no additional incision of the basement. Apparently fatal problems for accepting that scenario, however, concern how Sherwin drift could have crossed a second-generation gorge and why no Bishop Tuff remnants inset against basalt walls have survived. Moreover, the earliest package of Bishop Tuff ash flows (Ig1Ea of Wilson and Hildreth, 1997, 2003), $80 \mathrm{~m}$ thick in uppermost Owens Gorge, was completely blocked by the basalt-granodiorite high, failing to find any path through the basalt-filled reach of the once-and-future gorge (fig. 13). Furthermore, why would the river have reincised a convex-upward basaltic shield that filled the granodiorite gorge to its rim, rather than establishing a new course around the north or south toe of the basaltic edifice? We conclude that the 5-km-long basalt-filled reach of the granodiorite gorge was not re-excavated until after emplacement of the Bishop Tuff.

Alternatively, then, where could a late Pliocene-early Pleistocene reach of the Owens River have run after having been diverted from its former (Miocene-Pliocene) course through the granodiorite paleoridge by growth of the small basaltic shield that filled and blocked the gorge at 3.3 Ma? We consider three potential precaldera courses of the Owens River as alternatives to a route coinciding with the modern gorge - (1) a buried channel north of Owens Gorge, (2) one south of it, and (3) Lower Rock Creek.

\section{Buried Channel North of Owens Gorge?}

The highest exposure of the granodiorite paleoridge on gorge walls today is at $2,140 \mathrm{~m}$, and the highest remnant of the basalt is its vent complex (figs. 3,11,13) at 2,190 m, which is only $\sim 30 \mathrm{~m}$ higher than the 2,158-m highstand lake deposit at the modern outlet arm but $250 \mathrm{~m}$ higher than the basalt that flowed to the floor of the adjacent gorge (preserved as low as 1,940 m). For $\sim 5 \mathrm{~km}$ north of the outlet arm, along the shore of Lake Crowley, the Bishop Tuff extends an unknown distance below the 2,062-m reservoir level and would thus have filled and concealed any precaldera river course north of present-day Owens Gorge. North of the gorge, a plateau of Bishop Tuff separates the granodiorite in the gorge from Round Mountain (figs. 3, 5), a 2,340-m knoll of a different granodiorite pluton (Rinehart and Ross, 1957), which rises barely $20 \mathrm{~m}$ above the ignimbrite surface. If a saddle or notch through the north-trending granodiorite paleoridge were concealed beneath the ignimbrite plateau, it is conceivable that a precaldera course of the Owens River could have skirted north of the basaltic shield, perhaps rejoining the modern gorge downstream from the granodiorite window. We know of no evidence for or against such a northerly buried channel, but there is no trace of a compactional swale betraying a tuff-filled channel beneath the ignimbrite surface, and there is no obvious feature along the left-bank wall downstream along the gorge where such a paleochannel might have rejoined it.

\section{Buried Channel South of Owens Gorge?}

South of the modern gorge, the LADWP tunnel provides more control on topography beneath the ignimbrite (Putnam, 1960). Along the tunnel alignment between test holes $1-X$ and 

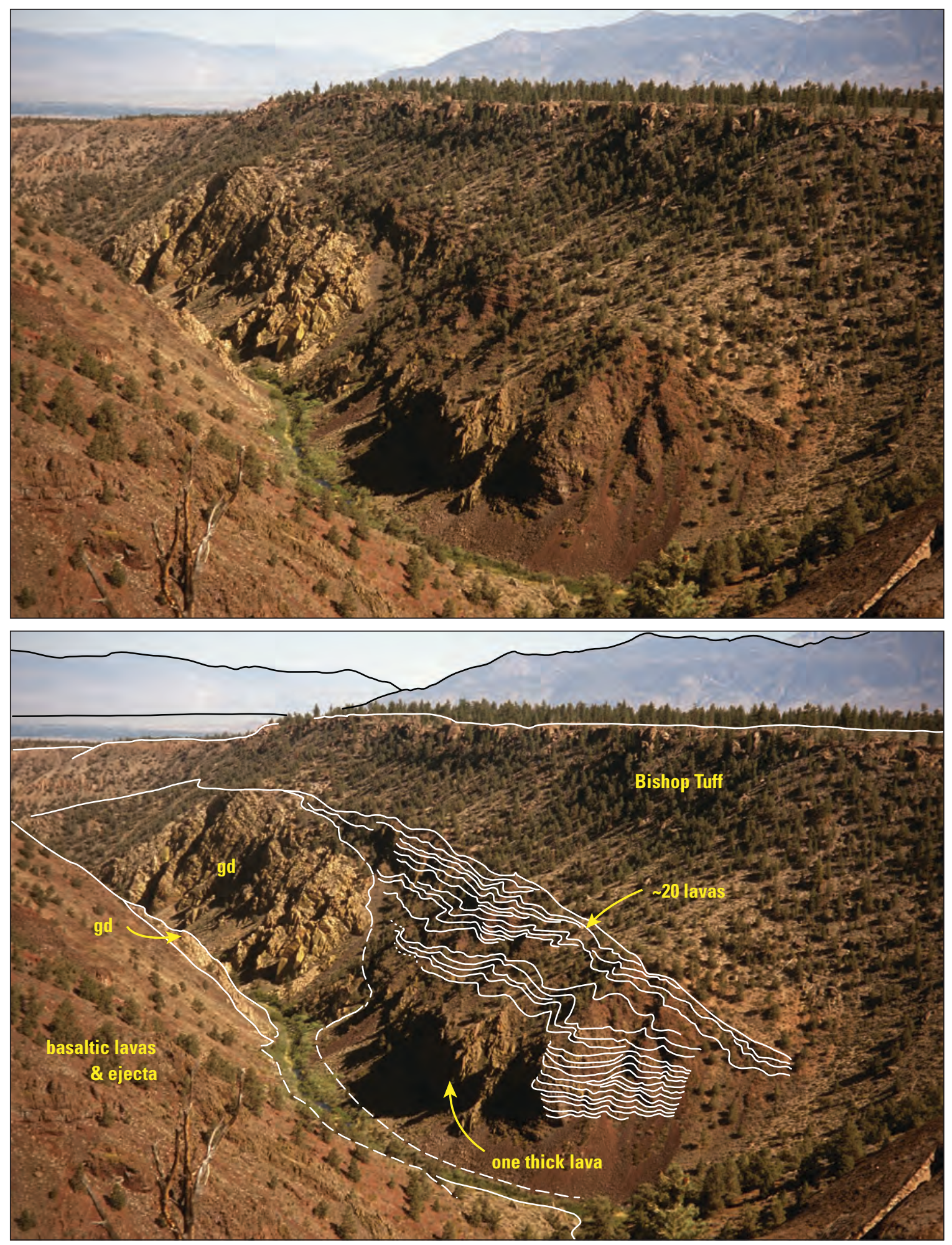

Figure 17. Owens River Gorge viewed southward from left-bank rim, showing basalt draping granodiorite (gd) and extending to canyon floor. Opposite (right-bank) wall of gorge is $230 \mathrm{~m}$ high. Basaltic buttress $\sim 90 \mathrm{~m}$ thick at lower center (at UTM 572/583) consists of an atypically thick 20-m flow at riverside, overlain by $\sim 20$ thin rubbly flows that dip $20^{\circ} \mathrm{SW}$. (to right). These are overlain in turn by $140 \mathrm{~m}$ of Bishop Tuff, which extends to the rim. Basalt stack thins to left (downstream) over granodiorite buttress, which is here $\sim 100 \mathrm{~m}$ high. At lower left, thin basaltic lavas, red scoria, and agglutinate dip $20^{\circ} \mathrm{SW}$. into gorge, forming a $190-\mathrm{m}$-thick sequence that mantles granodiorite wall all the way to riverside. Owens River, now a controlled stream, is largely concealed by bushes along the canyon floor. In far distance, Owens Valley and White Mountains rangefront at upper left; Coyote Warp segment of Sierran rangefront at upper right. 
1-A (respectively 0.8 and $1.7 \mathrm{~km}$ south of the present gorge floor; figs. 6, 11), the Bishop Tuff is 180-220 m thick and its base ranges in elevation between 1,980 and 2,020 m. Along the same reach of the tunnel, the base of the Sherwin Till (resting on granodiorite) lies generally below $1,920 \mathrm{~m}$ and as deep as $1,833 \mathrm{~m}$ asl in test hole 1-X (fig. 6). On the gorge floor $1.7 \mathrm{~km}$ north of test hole 1-A, the base of a 200-m-thick section of Bishop Tuff rests on granodiorite at an elevation of 2,010 $\mathrm{m}$. These relations permit the possibility that a pre-Sherwin channel of the Owens River flowed southeastward at an elevation 90-170 m lower than the present floor of Owens Gorge and as much as $1.7 \mathrm{~km}$ south of it. Such a channel, now wholly concealed by Bishop Tuff, could have started from the Z-bend in the modern gorge ( $\sim 2 \mathrm{~km}$ downstream from the dam), where the Owens River turns sharply to the southeast, then back to the east (figs. 3, 11). Within 2-3 km southeast of test hole 1-A (fig. 11), however, such a paleo-channel would have encountered the granodiorite ridge, which widely rises higher than the surface of the Bishop Tuff and Sherwin Till. It is unlikely that this hypothetical pre-Sherwin river course found a concealed gap through the basement high, and no site is recognized downstream from the basalt-filled blockage where such a channel could have joined the right-bank of the modern gorge.

\section{Buried Channel Diverted from Owens Gorge to Rock Creek Gorge}

The upper end of Lower Rock Creek gorge (east of Toms Place) is $6 \mathrm{~km}$ southeast of the dam and $4 \mathrm{~km}$ southeast of the Z-bend in Owens Gorge (figs. 3, 11). The area between is covered entirely by thick Bishop Tuff and includes the reach of the LADWP tunnel near test hole 1-X, mentioned above, where granodiorite basement is $\sim 177 \mathrm{~m}$ deeper than on the floor of Owens Gorge less than $2 \mathrm{~km}$ away. Rock Creek, after skirting the edge of the Bishop Tuff plateau near Toms Place, today turns southeast and for $4 \mathrm{~km}$ becomes increasingly entrenched in Sherwin Till as thick as $200 \mathrm{~m}$ before encountering the north-trending basement paleoridge, through which it flows in a sharp gorge with granodiorite walls as high as $220 \mathrm{~m}$. Where Rock Creek descends through till into granodiorite, its bed is at $\sim 1,900 \mathrm{~m}$, similar in elevation to the granodiorite floor of Owens Gorge $4 \mathrm{~km}$ northeast, where it runs parallel to Rock Creek (fig. 11).

Like the granodiorite gorge of the Owens River, that of Rock Creek had a lengthy ancestral (pre-Quaternary) development, and much of its depth existed before deposition of the Sherwin Till. Sherwin drift extends eastward to the present site of the Owens River, but one lobe of the Sherwin glacier turned southeast and banked against and partly overran the basement high through which Rock Creek had previously cut a deep gorge along its course toward Round Valley (figs. 3, 11). Sherwin Till is preserved at the upper end of the granodiorite gorge where a left-bank remnant extends $\sim 100$ $\mathrm{m}$ into the gorge near its floor. Moreover, $\sim 600 \mathrm{~m}$ farther downstream, a 35-m-thick remnant of Sherwin Till ( 150 $\mathrm{m}$ long) is inset against the left-bank wall of the granodiorite gorge (UTM 558/538 at elevations $\sim 1,880-1,915 \mathrm{~m}$ ), its base $\sim 20 \mathrm{~m}$ above the modern stream on the gorge floor. The remnant is typical Sherwin Till, dominated by grussy boulders of Wheeler Crest Granodiorite, many larger than $50 \mathrm{~cm}$ and a few as big as $1 \mathrm{~m}$, accompanied by subordinate dioritic, amphibolitic, leucogranitic, and metasedimentary stones. All are readily distinguished from angular granitic and metasedimentary blocks of modern rockfall colluvium from the gorge wall. We conclude that the granodiorite gorge of Rock Creek, like that of Owens Gorge, was cut prior to the Sherwin glacial episode.

We know of no evidence against a pre-Sherwin paleochannel of the Owens River having left the vicinity of the modern Z-bend ( $\sim 2 \mathrm{~km}$ downstream from the dam) and having flowed southeast to the granodiorite gorge of Rock Creek along a 7-km-long reach subsequently completely buried by Sherwin Till and Bishop Tuff. Aligned with the Z-bend and test hole 1-X, where the base of the Sherwin Till is $\sim 177 \mathrm{~m}$ deeper than the nearby granodiorite floor of Owens Gorge, there is today, eroded across the surface of the Bishop Tuff, a southeast-trending dry valley that joins Rock Creek where it crosses Highway 395. This may or may not represent a weak surface expression of the buried paleochannel. We conclude that the simplest and most likely postbasalt pre-Sherwin course of the Owens River ran southeast from the uppermost (basalt-free) reach of Owens Gorge, bypassed the southwest toe of the 3.3-Ma basaltic shield, and flowed toward and through the granodiorite gorge of Lower Rock Creek (fig. 11).

Sherwin ice and drift later $(\sim 0.88 \mathrm{Ma})$ buried the proposed paleochannel and all of Rock Creek upstream of its granodiorite gorge (fig. 11). The Sherwin glacier, which may have had a long and fluctuating history of advances and drainage patterns, would thus have forced the Owens River back toward its own older gorge, the basalt-filled segment of which had been abandoned since 3.3 Ma. Sherwin meltwater would have drained both into Lower Rock Creek and into the long-abandoned reach of Owens Gorge downstream from the basaltic blockage.

Despite the forced changes in its course, the Owens River necessarily remained the principal regional stream, continuing to drain precaldera Long Valley and parts of the Sierra Nevada and of what later became Mono Basin (fig. 1).

Between test hole 1-C and gorge-wall exposures just north of the surge tank (figs. 6, 11), the base of the Sherwin drift descends eastward by $80 \mathrm{~m}$ within $1 \mathrm{~km}$ (Putnam, 1960), an unusually steep pitch that may mark the point of return of one meltwater stream (during the $\sim 880-767 \mathrm{ka}$ interval) into the Pliocene course of the Owens River downstream from the basaltic blockage. Notably, this location is close to the only site of unequivocal Sherwin fluvial outwash (fig. 18) we encountered (UTM 595/564) along the gorge. Another meltwater stream from the Sherwin glacier concurrently flowed down Rock Creek. 
About 100,000 years after the Sherwin glacial episode, emplacement of the Bishop Tuff (767 ka) buried all preexisting topography, including the basalt-filled basement high, the previously unfilled segments of Owens Gorge upstream and downstream from the high, and the canyon of Rock Creek. This demanded a new generation of canyon cutting along all segments to establish the unobstructed gorges of modern Owens River and Rock Creek. Erosion of thick Bishop Tuff from 30-km-long Owens Gorge, linked in part to overflow of Long Valley's caldera lake, is discussed in the concluding section below.

\section{Erosion of the Ignimbrite Surface}

As noted above, the intricately eroded (but poorly drained) surface of the Bishop Tuff that forms the upper Volcanic Tableland has a barely perceptible south-trending drainage divide that separates gentle upland slopes toward Long Valley and Owens Valley (figs. 3, 5, 11, 13). The crest of the ignimbrite divide is as high as $2,320 \mathrm{~m} \sim 3 \mathrm{~km}$ north of Owens Gorge (near Round Mountain), provides the high point along the gorge rim $(2,230 \mathrm{~m} ; 5-6 \mathrm{~km}$ east of the dam), and maintains elevations of 2,210-2,220 m south of the gorge as far as Rock Creek. This broad crest of the ignimbrite surface trends north-south across the gorge, crosses it where the upstream-most outcrops of granodiorite are exposed on the gorge floor, and generally parallels the partly buried granodiorite-basalt paleoridge $\sim 2 \mathrm{~km}$ west of its north-south chain of basement windows (fig. 11). West of the ignimbrite divide, the gorge rim descends from a high of 2,230 $\mathrm{m}$ to $2,158 \mathrm{~m}$ at the wave-cut highstand bench on the north rim and to as low as $2,100 \mathrm{~m}$ south of the dam. In analyzing how the lake may have drained, it is important to consider the extent to which the $80-130 \mathrm{~m}$ westward backslope of the ignimbrite surface toward the outlet of Long Valley Lake might variously reflect erosion, differential compaction, faulting, or tectonic warping.

The high shoreline has clearly been warped southward (figs. 9, 10) and so has the adjacent Bishop Tuff surface. The modern surface slope of the ignimbrite from the divide to the lake outlet, however, is westward (figs. 11-13), perpendicular to the regional tectonic tilting, and if there is a lakeward component of tilt, it is small. Along the east-trending segment of Owens Gorge, near-horizontality of the Ig1Ea/Ig1Eb contact (fig. 13) and of the lithic-concentation contours within Ig1Eb (figs. 1, 5, 11 of Wilson and Hildreth, 2003) indicate that westward tectonic tilting is negligible. Welding zones within Ig1E west of the buried granodiorite ridge may dip faintly westward $\left(\leq 1^{\circ}\right)$, probably reflecting compaction of welded tuff that thickens away from the basement high it drapes (see fig. 11 of Wilson and Hildreth, 2003, which has 20 -fold vertical exaggeration). Near the east-trending reach of the gorge upstream of the basement high, welding zones also incline gently $\left(\sim 1^{\circ}\right)$ north and south toward the gorge axis, reflecting differential compaction and welding where the tuff was thickest. Nonetheless, because much of the tuff between the basement high and Lake Crowley is only moderately welded, the contribution of differential compaction to the westward backslope appears to be modest.

A few north-trending normal faults are depicted by Putnam (1960) and Bailey (1989) on the west-sloping part of the ignimbrite plateau. We question the existence of most of those faults; certainly none offsets the rimrock or welding zones exposed along the gorge by more than a meter; and, as depicted by Putnam and Bailey, down-to-the-east displacements are as common as those down-to-the-west. If minor extensional faults did actually exist there, they would thus provide no net contribution to the westward slope of the ignimbrite surface. The gentle westward slope, now toward Lake Crowley and formerly toward Pleistocene Long Valley Lake, principally reflects surface erosion of the Bishop Tuff, which makes a far greater contribution to the slope than do faulting, westward warping, or differential compaction. This discussion refers only to the slope west of the divide. East of the divide, the upper Volcanic Tableland is cut by several north-trending faults that displace the Bishop Tuff by 25-60 m, east-side-down (figs. 11, 13).

On distal parts of the Volcanic Tableland, well east and southeast of the caldera, fumarolic mounds are abundant in several areas where thick sections of devitrifying welded tuff supplied gas to extensive zones of vapor-phase crystallization above them (Bateman, 1965; Sheridan, 1970). The fumarolically indurated mounds rise 5-15 $\mathrm{m}$ (and rarely as much as $30 \mathrm{~m}$ ) above the surrounding plateau surface of poorly welded tuff, providing a minimum measure of the reduction of such surfaces by deflation and sheetwash. Maps of the sequence of ignimbrite emplacement packages (fig. 12 of Wilson and Hildreth, 1997) show that stripping of the late-emplaced Ig2 package was still greater west of the basement high, in the proximal area relevant to the present discussion.

North and south of the outlet arm and uppermost Owens Gorge, a shallow bight of the Pleistocene lake at its highstand (figs. 5,11 ) planed broad wave-cut benches covered with littoral gravels across ignimbrite packages Ig1Ea and Ig1Eb. On the south rim of the gorge $1.4 \mathrm{~km}$ east of the dam, knoll 2162 (fig. 11) is an erosional remnant of Ig2 that rises $40 \mathrm{~m}$ above the paleo-shoreline cut around its base. Just south of the dam, several ragged knolls of Ig1 stand as former islands and peninsulas $\sim 10 \mathrm{~m}$ higher than the paleo-shoreline, and they retain no overlying remnants of Ig2. It can be inferred that most of Ig2 and part of Ig1Eb were eroded from surfaces near the outlet arm before the Pleistocene lake ever rose high enough to invade the area. At least $50 \mathrm{~m}$ and conceivably as much as $80 \mathrm{~m}$ of Bishop Tuff was stripped to produce the west-sloping ignimbrite surface north and south of the upper gorge and outlet arm (figs. 11-13). 


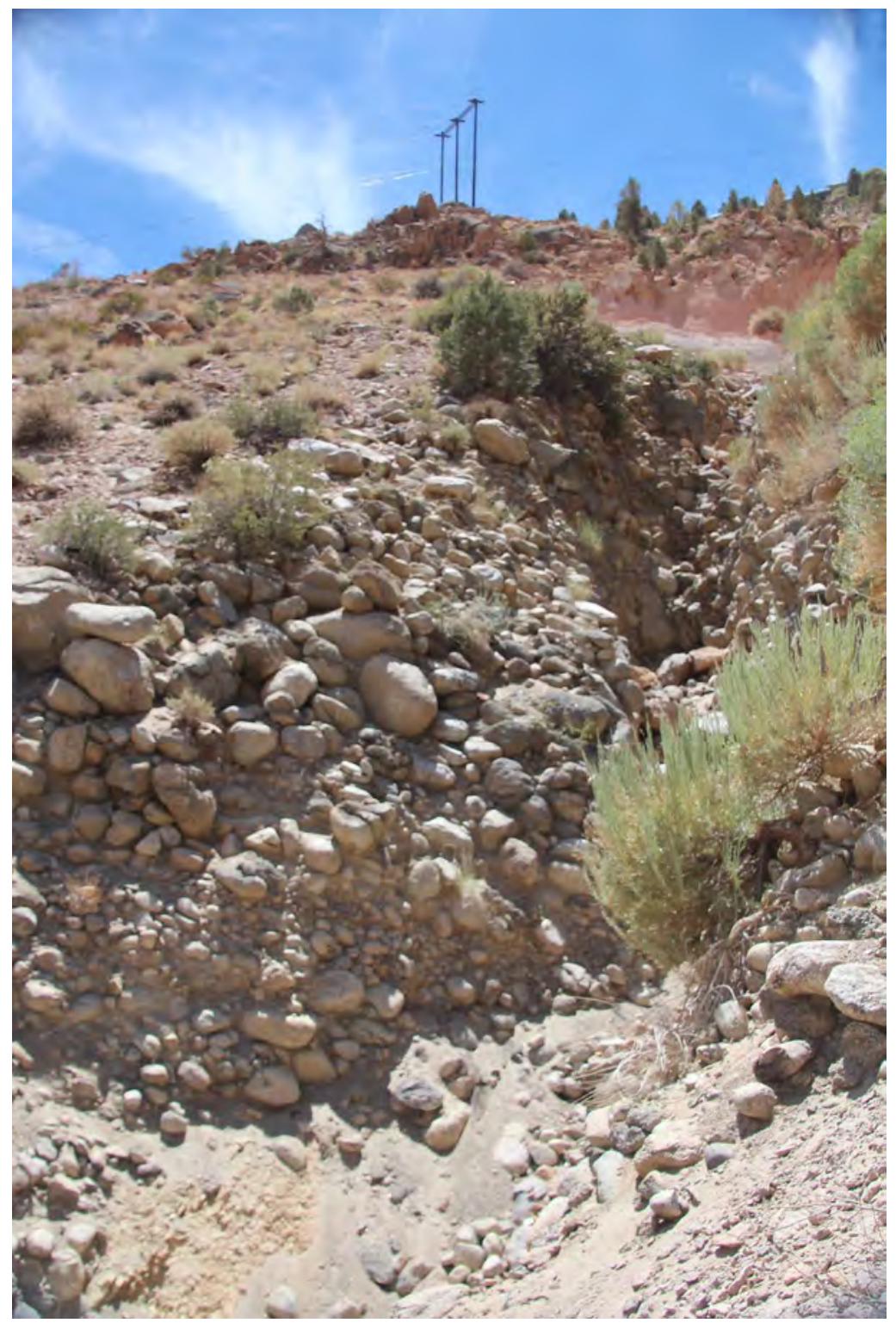

Figure 18. Sherwin outwash exposed in gully midway up right-bank wall of Owens Gorge (UTM 595/564), 200 $\mathrm{m}$ west of power house \#1 (figs. 3, 11). Unlike numerous gorge-wall exposures of Sherwin Till, this bouldery deposit is matrix-poor. Like the till, nearly all clasts are rounded granodiorite. Deposit is $\sim 25 \mathrm{~m}$ thick, crops out at elevations 1,890-1,915 $\mathrm{m}$ above sea level, and rests on granodiorite basement. Many boulders are $30-80 \mathrm{~cm}$ in diameter. In right background, white plinian deposit overlain by pink nonwelded zone marks base of Bishop Tuff, which is $140 \mathrm{~m}$ thick here and mostly welded.

\section{Little Round Valley}

Erosive removal of the ignimbrite from Little Round Valley (figs. 3, 5, 11, 19), 2-4 km south of the dam, was more profound still. Fringes of nonwelded ignimbrite survive on all sides of the 2,070-m meadow that today floors the nearly enclosed bowl of that name. A ridge of Ig1 as high as 2,224 m borders the bowl on the north, and the west wall of the bowl is a ridge of Bishop Tuff that rises southward from $\sim 2,180 \mathrm{~m}$ to $2,290 \mathrm{~m}, 215 \mathrm{~m}$ higher than the meadow floor (figs. 11, 15C, 19). The ridge is mostly Ig 1 , but four knolls along its crest are capped by remnants of Ig2. If the tuff that filled $5-\mathrm{km}^{2}$ Little Round Valley had been on average $210 \mathrm{~m}$ thick, then $1.05 \mathrm{~km}^{3}$ is missing; or, if the initial ignimbrite surface had sloped evenly northward toward bowl-enclosing ridge 2224 , then a minimum volume of $0.7 \mathrm{~km}^{3}$ has been removed.

This major excavation took place before Long Valley Lake ever filled deep enough to spill over into Little Round
Valley. When it did so, by way of lower Crooked Creek gorge at the time of the lake's highstand, the Little Round Valley embayment was confined to the floor of the bowl and was no deeper than $\sim 30 \mathrm{~m}$. Its strandline at a present-day elevation of $\sim 2,100 \mathrm{~m}$ reflects post-lake southward tilting by $\sim 50 \mathrm{~m}$ relative to the 2,150-m highstand only $3 \mathrm{~km}$ north. As noted earlier, had the lake embayment in Little Round Valley ever reached a pre-tilt level of $2,150 \mathrm{~m}$, it would have overflowed eastward into Rock Creek, which it did not do. Were it not for the large alluvial fan first constructed in the middle Pleistocene at Toms Place (fig. 11), Long Valley Lake could have drained to Rock Creek (as the Owens River had in post-basalt pre-Sherwin time), and postcaldera Owens Gorge need never have been cut.

Three streams could have participated in eroding the tuff from Little Round Valley: Crooked Creek and two channels of Rock Creek. Long Valley Lake did not. During and since the middle Pleistocene, near Toms Place, Rock Creek has built a 
coarse alluvial fan, down which the stream divides into a pair of distributaries that turn west into Little Round Valley and a third that turns east into Lower Rock Creek gorge (fig. 11). A smooth curvilinear scarp of south-facing Bishop Tuff that extends from Toms Place to Crooked Creek is the work of the larger western distributary of Rock Creek, which flowed (via lower Crooked Creek gorge) into Long Valley Caldera long before the Pleistocene lake attained its highstand and threshold of overflow. The southern west-flowing distributary of Rock Creek (now artificially controlled for irrigation) crosses a granite saddle into the southeast corner of Little Round Valley and was probably only a subordinate contributor to the erosion. On the other hand, upper Crooked Creek, which flows northward through a granodiorite gorge (fig. 19) into uppermost Little Round Valley, is likely to have been the major agent of erosion. Its course was aligned with the main north-flowing reach of upper Rock Creek (southwest of the area of figure 11), from which it became separated only by emplacement of a large Tahoe (MIS 6) moraine (Rinehart and Ross, 1957; fig. 19). Prior to the Tahoe-age blockage and to inundation of the bowl floor by the rising Pleistocene lake, the three streams had more than half a million years to erode $200 \mathrm{~m}$ of Bishop Tuff out of Little Round Valley.

After withdrawal of the lake from Little Round Valley, talus, alluvium, and avalanche tongues of angular granite blocks have covered much of the southern fringe of Bishop Tuff and locally encroached beyond it onto the meadow floor. The granitic debris is the lower end (at 2,100 m) of an enormous talus apron that spans the entire south slope of Little Round Valley (figs. 11, 19) and extends up the Sierran front to as high as 2,800 m (Rinehart and Ross, 1957). A prominent roadcut in Little Round Valley (at UTM 482/578) displays incorporation of some of the overrun talus by the nonwelded base of the ignimbrite and later scour of the ignimbrite surface by avalanche sheets from higher parts of the talus apron. Others have speculated that features in this exposure reflect emplacement of the Bishop Tuff atop a glacier postulated to have occupied Little Round Valley at the time of the eruption (Bailey, 1989, p. 8), but abundant evidence compels rejection of this suggestion. Nonwelded Bishop Tuff survives as fringes around much of the floor of the bowl, and moraines are not present anywhere within the nearly closed bowl. There are a few ordinary degassing pipes in the (near-basal) tuff in the roadcut, but there is no pervasive vapor-phase alteration. There is no till at all but, instead, an enormous talus slope that drapes the Sierran granitic wall for $>700 \mathrm{~m}$ above the floor of Little Round Valley (fig. 19), showing that there had been no glaciation here, at least since before Sherwin time (MIS 22).

Crooked Creek gorge, which today drains Little Round Valley, is graded to the drowned floor of the outlet arm, to $\sim 2,037 \mathrm{~m}$ beneath the reservoir, not to the high shoreline $(\sim 2,150 \mathrm{~m})$ of the Pleistocene lake, which produced inundation of both the outlet arm and Little Round Valley. The south-tilted shoreline is at $\sim 2,150 \mathrm{~m}$ just north of the dam and at 2,100 m 2-3 km south of it. Lower Crooked Creek is a narrow defile, cut entirely into Bishop Tuff, $>40 \mathrm{~m}$ deep and $\sim 100$ m wide, rim-to-rim, at its mouth. We don't know how much of the entrenchment of distal Crooked Creek took place (1) while it was draining into Long Valley before the Pleistocene lake's highstand, (2) rapidly during a threshold-lowering outbreak, or (3) after the lake drained and the outlet arm had been deepened and integrated with Owens Gorge. All three may have contributed to shaping the present-day course of lower Crooked Creek through the Bishop Tuff.

\section{Headward Erosion of Owens River Gorge?}

Several considerations render unlikely the draining of Long Valley Lake by capture owing to headward erosion of Owens Gorge. Of the scant precipitation on the Volcanic Tableland ( $\leq 200 \mathrm{~mm}$ annually), much falls as snow, which either sublimates or infiltrates slowly as meltwater. The intricately fractured surface of the welded ignimbrite favors infiltration, resulting in few major arroyos but numerous shallow ephemeral gullies, many of them closed. Sierran runoff adjacent to the Volcanic Tableland is intercepted by Rock Creek, thus not reaching the Owens River. Poor development of integrated arroyo systems across the Volcanic Tableland suggests that surface runoff was not far greater during pluvial episodes. Historic streamflow of Owens River, even before construction of the dam and reservoir, was relatively modest. Before breaching the ignimbrite/basalt/granodiorite divide and capturing Long Valley Lake, a stream advancing headward up the Volcanic Tableland would need to have been almost exclusively spring-fed. Despite the present-day $900-\mathrm{m}$ descent and $2^{\circ}$ average gradient of the Volcanic Tableland, much of the Owens Gorge is sinuous and marked locally by tight meanders, suggesting antecedence of a lower-gradient stream that became entrenched. Wahrhaftig's (1965) case against headward capture was cited above in the summary of previous investigations.

It would be implausibly coincidental that shoreline gravels (not fluvial gravels) were deposited along the rims of the uppermost $2.4 \mathrm{~km}$ of Owens Gorge during the highstand of Pleistocene Long Valley Lake unless this narrow arm of the lake, lowest point on the rim of the entire Long Valley hydrographic basin, eventually became the threshold of overflow and the starting point for re-excavation of the ignimbrite-filled gorge. The case for reverse-headward erosion, advancing eastward from the outlet arm, is presented in a concluding section, below.

\section{Age of the Highstand}

Several lines of evidence place limits on the age of the high shoreline of Pleistocene Long Valley Lake. It seems likely, though not required, that filling of the basin to its threshold for overflow took place during a pluvial interval, of which there were several in postcaldera time. Numerous studies in the Great Basin indicate that pluvial lake expansion reflected increased runoff associated with Sierran glacial 


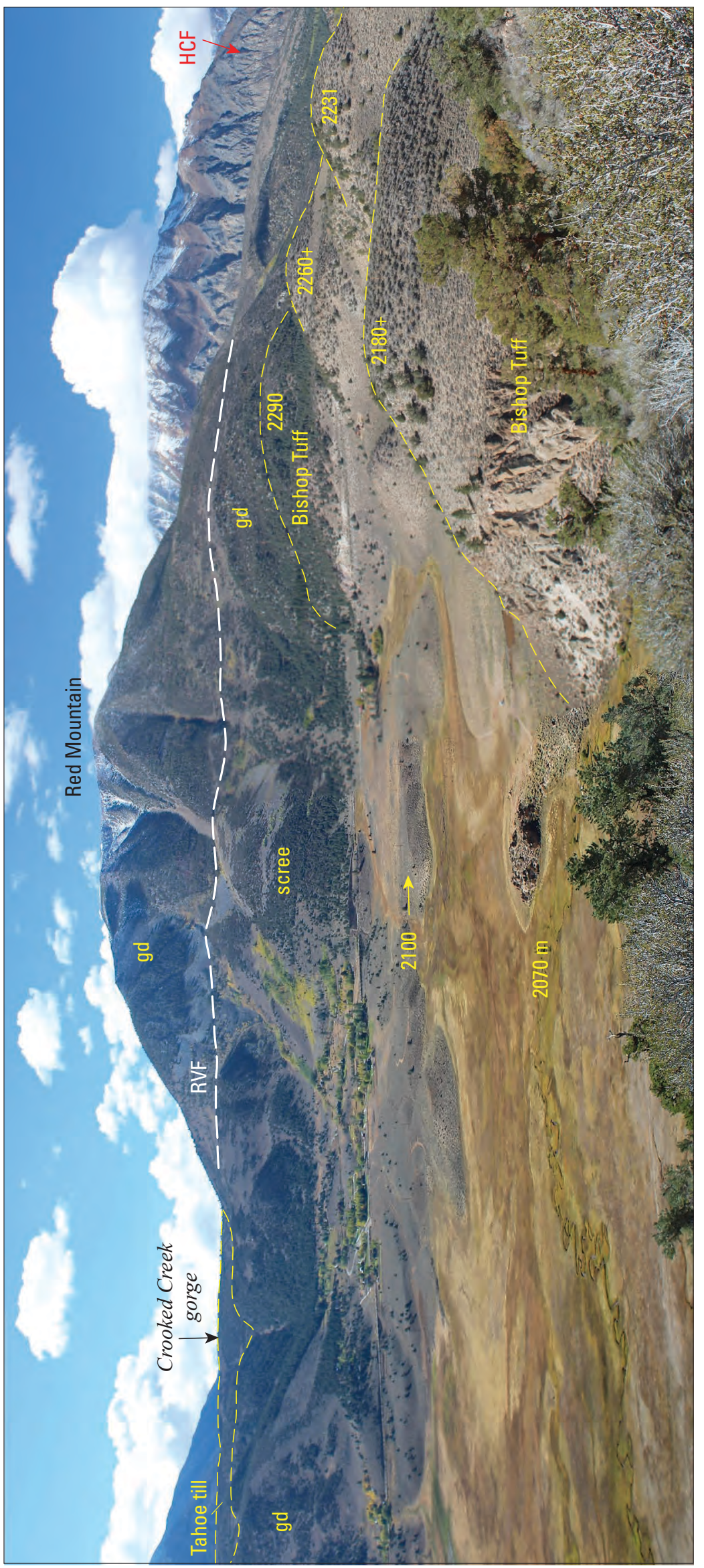

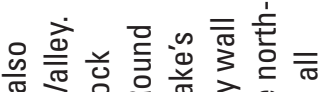

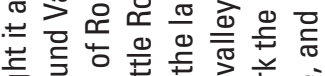

돈

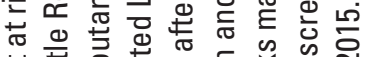

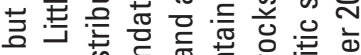
ब.

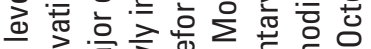
त्र

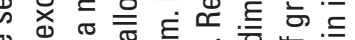

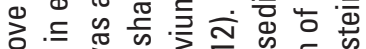

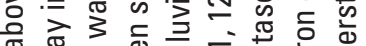

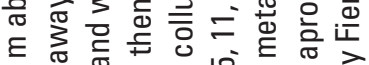

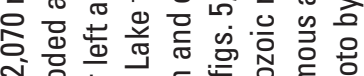

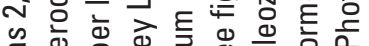
i

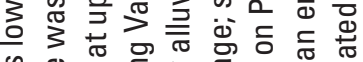

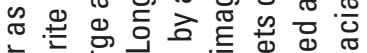

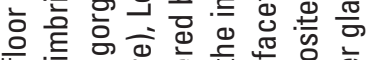

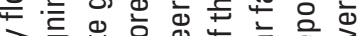

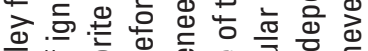
琼

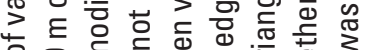

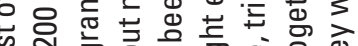

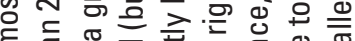
E

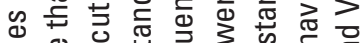

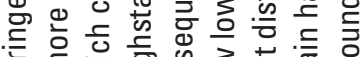

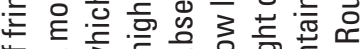

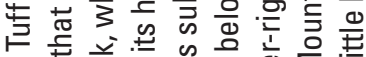

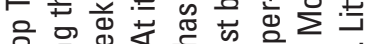
돈

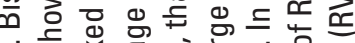

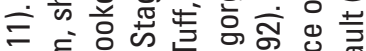

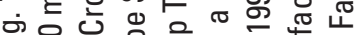
实冬 สิ่

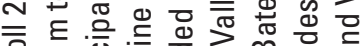
흐을

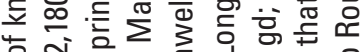

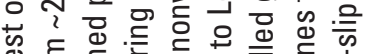

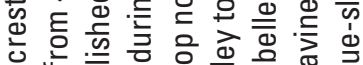

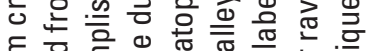
일 흥

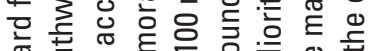

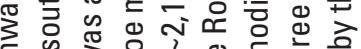

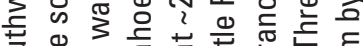
里. क

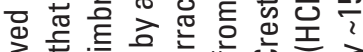

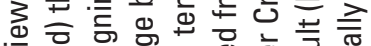
.

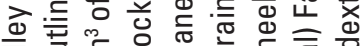

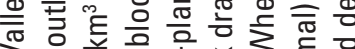

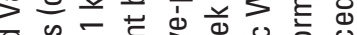

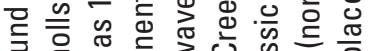
व

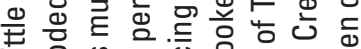

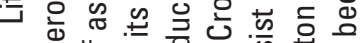

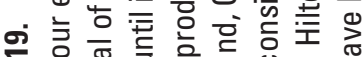
닌

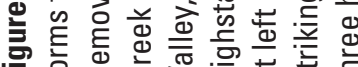


episodes that correlate with MIS 2, 4, and 6 (Kurth and others, 2011). For several hydrologic basins in Nevada, Reheis (1999) and Reheis and others (2002) identified Pleistocene shoreline features that are both higher and older than the better known highstands of MIS 2, 4, and 6. A major expansion of Great Basin lakes during MIS $16(\sim 650 \mathrm{ka})$ was followed by at least two more highstands older than MIS 6, probably representing MIS $12(\sim 450 \mathrm{ka})$ and MIS $10(\sim 350 \mathrm{ka})$. For Pleistocene lakes in the western Great Basin, Reheis and others (2002) found generally lower shorelines with time, a regional trend toward shrinking highstands and decreasing effective precipitation, perhaps linked to secular elevation of the Sierra Nevada and its rainshadow. Smith and others (1997) showed that Owens and Searles Lakes (downstream along the Owens River system) were fresh and overflowing in MIS 16, 12, 10, and 6. Nonetheless, Long Valley Lake was a special case, a deep basin that formed abruptly at $767 \mathrm{ka}$ and endured through several glacial-pluvial episodes before finally filling to its level of overflow. It remained unconnected to downstream Owens River until it breached.

G.I. Smith (1976) proposed that much of the Li, B, Cl, and $\mathrm{SO}_{4}$ in Searles Lake deposits, far downstream on the Owens River, originated from Long Valley thermal areas. His data were at first limited to the late Pleistocene, but 930-m-deep core hole KM-3 later penetrated the entire sedimentary sequence in central Searles Lake (Smith and others, 1983). Those authors and Sorey (1985) appealed to a compositional change in the KM-3 core sediments at $\sim 310 \mathrm{ka}$, which they thought might reflect a pulse of hydrothermal activity in Long Valley Caldera that Bailey and others (1976) speculated to have taken place around $280 \mathrm{ka}-$ the K-Ar glass age of the Hot Creek rhyolite coulee, for which ${ }^{40} \mathrm{Ar} /{ }^{39} \mathrm{Ar}$ dating later gave a sanidine age of $333 \pm 2 \mathrm{ka}$ (Simon and others, 2014). Sorey and others (1991) later determined U-series ages for hydrothermal silica deposits around the toe of the resurgent uplift in the range 310-210 ka. Linkage of such an episode of hydrothermal activity in Long Valley to the geochemistry of sediments in Searles Lake, $250 \mathrm{~km}$ downsteam on the Owens River, however, assumes that Long Valley Lake was by then overflowing southward, rather than still filling toward its threshold. Scrutiny of the abundant chemical data for KM-3 core (Smith and others, 1983, fig. 3, plate 2) shows a big increase in carbonate precipitation around $310 \mathrm{ka}$, but no telltale change in $\mathrm{Na}, \mathrm{K}, \mathrm{Li}, \mathrm{B}, \mathrm{Br}, \mathrm{Cl}$, or $\mathrm{SO}_{4}$, as might be expected if there had been an influx associated with breakout of Long Valley Lake. Smith's final evaluation of the Searles Lake data led him to conclude that there is no evidence for significant boron or lithium influx from upstream until the past 100,000 years (G.I. Smith, oral commun., 2003).

\section{Lava Flows With and Without Shoreline Features}

On the caldera's resurgent uplift, many of the early rhyolite lavas ( $750-640 \mathrm{ka})$ are locally overlain by sandstone, lakeshore gravels, and ice-rafted erratics, and some exhibit wave-cut scarps or benches of dense perlite. In the caldera's southeast moat, several small rhyolite domes and flows are surrounded and partly concealed by lacustrine sandstone, siltstone, and tufa (Bailey, 1989); four have given ages in the range 362-329 ka (Mankinen and others, 1986; Heumann, 1999). The 333-ka Hot Creek rhyolite coulee flowed northward into the lake, which subsequently deposited sandstone on and around much of its perimeter and buried its distal terminus, indicating that the lake lasted at least as long as early MIS 8 (300-243 ka).

In the caldera's south moat, six different mafic lava flow complexes that gave ${ }^{40} \mathrm{Ar} /{ }^{39} \mathrm{Ar}$ ages in the range $172 \pm 2$ to $92 \pm 2 \mathrm{ka}$ (units bcd, bfh, bsc, bsr, mlc, and mmc of Hildreth and others, 2014) extend down to elevations low enough to have encountered Long Valley Lake but did not do so. In particular, the basaltic sheet of unit bsc (172 2 ) crops out as low as 2,170 m south and east of Chance Ranch (CR, fig. 5) and shows no sign of lake deposits or shoreline erosion. In order to confirm this key age, a sample was dated from another part of the lava flow, and it gave an analytically indistinguishable age of $169 \pm 6 \mathrm{ka}$. A seventh mafic lava (unit mcl; $180 \pm 3 \mathrm{ka}$ ), which crops out adjacent to the Casa Diablo geothermal plant and within $1 \mathrm{~km}$ of the other six mafic units, forms a knoll that is surrounded and lapped by littoral sandstone that extends to elevations as high as $2,230 \mathrm{~m}$. These relations suggest that the lake reached an early MIS-6 (191-130 ka) highstand here at $\sim 180 \mathrm{ka}$ but that its level dropped $50-60 \mathrm{~m}$ by $\sim 172 \mathrm{ka}$. A nearby moraine of Casa Diablo Till, bracketed by Ar-dated lava flows to an MIS- 6 age between $162 \pm 2$ and $125 \pm 2$ ka (Hildreth and others, 2014), extends as low as $2,225 \mathrm{~m}$ in the south moat but shows no sign of interaction with the lake.

Other dated lavas further demonstrate the absence of an extensive caldera lake during the late Pleistocene (130-11 ka). Along the caldera's north moat, a long tongue of basaltic lavas (unit bar of Hildreth and others, 2014), which extends as low as 2,120 $\mathrm{m}$ at Inaja Ranch (IR, fig. 5) and gave ${ }^{40} \mathrm{Ar} /{ }^{39} \mathrm{Ar}$ ages of 90-100 ka, shows no evidence of lake erosion or deposition, despite nearby north-moat shoreline gravels as high as $2,265 \mathrm{~m}$ and travertine sheets (containing remains of marsh plants) as high as $2,170 \mathrm{~m}$. Likewise in the north moat, rhyodacite dome 7403 (2,256 m), undated but presumed late Pleistocene in age, rises steeply from a base $\sim 2,145 \mathrm{~m}$ and shows no evidence of lake action. The 110-m-high dome is everywhere glassy and mostly finely pumiceous, but it exhibits no tufa, erratics, shoreline shingle, or wave-rounding of its fringing talus, despite highstand gravels as high as $2,265 \mathrm{~m}$ on the caldera wall $<1 \mathrm{~km}$ away.

In a quarry (UTM 4038/7186) near Cashbaugh Ranch (CRR, fig. 5) in central Long Valley, a primary pumice-fall from Mammoth Mountain, as thick as $\sim 91 \mathrm{~cm}$ and ${ }^{40} \mathrm{Ar} /{ }^{39} \mathrm{Ar}$ dated at $80 \pm 8 \mathrm{ka}$ (Hildreth and others, 2014), underlies Pleistocene alluvium and rests upon $\sim 1 \mathrm{~m}$ of tan sand that seals the top of the main undeformed lake-silt section.

In areas that were little affected by the post-highstand tectonic warping so evident along the southeast shoreline, evidence from lava flows along the north and south moats 
therefore suggests that the level of Long Valley Lake was well above $2,200 \mathrm{~m}$ before $\sim 180$ ka but dropped substantially soon thereafter. Moat basalts untouched by the lake and unaffected by resurgence require that lake level in the south moat had dropped below 2,170 $\mathrm{m}$ before $172 \mathrm{ka}$ and below 2,150 m before $92 \mathrm{ka}$. In the north moat its level was lower than 2,120 m before $100 \mathrm{ka}$.

\section{Ages of Lacustrine Tufa}

Tufa deposits-lacustrine carbonate typically precipitated by nearshore mineral springs at near-ambient temperatures-drape bedrock slopes at sparse locations not far below highstand shorelines along the southeast and north margins of Pleistocene Long Valley Lake. Dense tufa from three sites was dated by U-series spectrometry at the Berkeley Geochronology Center.

South of the Watterson Canyon highway, where texturally varied tufa drapes a 27-m-high wave-cut scarp of Bishop Tuff, we sampled dense concentrically laminated mammillary tufa midway up the scarp at 2,120 m elevation (UTM 4867/6712; table $1, \mathrm{M}-1000$ ). The scarp rim at $\sim 2,130 \mathrm{~m}$ is capped by a sheet of well-rounded all-rhyolite shingle that mantles a waveplaned terrace of Bishop Tuff that rises gently southeast past a paleo-island (of Bishop Tuff) at 2,160 m and continues $2 \mathrm{~km}$ farther southeast to the high strandline at 2,200 $\mathrm{m}$ (fig. 10). The tufa site is $\sim 6 \mathrm{~km}$ north of the intersection of the highstand with Owens Gorge at 2,158 m.

At a second site (UTM 4833/6685; table 1, M-1029B), $500 \mathrm{~m}$ east of Layton Springs and $\sim 400 \mathrm{~m}$ southwest of the first, another thick drapery of tufa mantles a steeply eroded scarp of Bishop Tuff $\sim 30 \mathrm{~m}$ high. Here, we sampled dense mammillary tufa at the 2,121-m rim, where the tufa rests on Bishop Tuff and is overlain by and locally intercalated with well-rounded laketerrace gravels that cap a wave-cut platform that rises gently southeastward to as high as 2,200 m (figs. 5, 10). Like the first, this site is $\sim 6 \mathrm{~km}$ north of impingement of the highstand shoreline on the rim of Owens Gorge (fig. 5).

$\mathrm{U}$ and Th data and ages are given in table 1 for two independently processed samples from each site. $U$ concentrations are similar for all four samples ( $700 \mathrm{ppb})$, but ${ }^{232} \mathrm{Th}$ ranges from 225 to $616 \mathrm{ppb}$, concentrations that are higher and more varied than expected for pure authigenic carbonate. The biggest uncertainty in dating paleolake carbonates is the composition and amount of extraneous Th incorporated initially (for example, Placzek and others, 2006), representing either (1) siliciclastic detritus - generally silt or clay from regional dust clouds and stream-borne sediment or (2) unsupported "hydrogenous" Th-dissolved from the environment by alkaline lake water or excess ${ }^{230} \mathrm{Th}$ produced by decay of $\mathrm{U}$ in the water column. At Long Valley, dust from the ubiquitous surrounding rhyolites could have provided ample extraneous Th. Accordingly, model corrections for silicate detritus are indexed to ${ }^{232} \mathrm{Th}$, and both uncorrected and corrected ages are given in table 1. Because back-calculated ${ }^{234} U / 238 U$ ratios are fairly uniform and all four ages agree within measurement errors, we infer that the U/Th systems in these tufas became closed at about the same time and have remained so. The error-weighted mean of the four age determinations,

$257 \pm 16 \mathrm{ka}(2 \sigma)$, is thus our best estimate of the depositional age of the tufas somewhat below the southeast highstand of Long Valley Lake.

Another sample was analyzed from the north margin of Long Valley Lake, on the Inaja Ranch (fig. 5), where a 5-m-thick sheet of largely porous tufa drapes a knoll of Mesozoic granite (UTM 3827/8034; table 1, M-997) at an elevation of $\sim 2,160 \mathrm{~m}$. Dense laminated tufa was sampled midway up the 15-to-20-m-high granite-draping slope. The site here is $\sim 40 \mathrm{~m}$ lower in elevation than remnants of lakeshore gravels at the base of the caldera wall nearby. Although ${ }^{232} \mathrm{Th}$ concentrations (138-161 ppb) are lower than in the southeastern tufas and $U$ concentrations (736-768 ppb) are about the same, the subsample pair here yields somewhat different ${ }^{234} \mathrm{U} / 238 \mathrm{U}$ ratios (table 1) and gives corrected ages that do not overlap within the measurement errors-322 $\pm 14 \mathrm{ka}$ and $373 \pm 19 \mathrm{ka}$ - suggesting open-system modifications. Although these specific ages inspire little confidence, they might nonetheless be roughly meaningful. At varying unknown levels, the lake had existed since before $750 \mathrm{ka}$, but by $\sim 350 \mathrm{ka}$ it is unlikely to have reached a level as high as that associated with the $257 \pm 16 \mathrm{ka}$ southeast tufas (which have been lowered by $\sim 120 \mathrm{~m}$ to their present 2,120-m elevation by post-lake southward tilting; figs. $5,9)$. Highstand features on undeformed margins of the Hot Creek Coulee, which flowed into the lake at $\sim 333 \mathrm{ka}$, have elevations near 2,150 m, and tufa on a small adjacent rhyolite dome (also $333 \mathrm{ka}$ ) was deposited up to $2,158 \mathrm{~m}$, essentially the same elevation as the north moat (Inaja Ranch) tufa that was deposited at 2,160 $\mathrm{m}$ and dated at roughly $350 \mathrm{ka}$.

In the section titled "Shoreline Evidence," it was mentioned that sets of 3-5 shoreline terraces lower than the highstand are weakly preserved in six patches (appendix 2) around the margins of Pleistocene Long Valley Lake. Absence of significant tufa deposits associated with the five patches west of the lake supports our interpretation that the lake levels that etched these weak abrasional shorelines into indurated lacustrine sandstone represented short-lived stillstands during downcutting of the outlet that finally drained the lake.

\section{Tephra Layers Intercalated with Lake Silt}

The central part of the Long Valley lowland (fig. 5) contains many small hills and scarps of lacustrine silt and siltstone. Although the silt is known by drilling to extend to a depth of $\sim 700 \mathrm{~m}$, actual exposures of silt are typically only 10-25 m thick. Most are white to pale gray, laminated to thin bedded, and weakly indurated. Where preserved as flat-topped hillocks, their upper surfaces are virtually horizontal and armored by thin veneers of alluvial gravel. Cropping out for $\sim 7 \mathrm{~km}$ along the lake axis (fig. 12), all such planar surfaces have elevations of 2,090-2,115 $\mathrm{m}$ that decline southward along the basin floor. As discussed above in the section "Sedimentary Deposits of Long Valley Lake," the thickness of silt 
stripped from such mesas by post-lake erosion is uncertain, as is the water depth at the time of their deposition, but they clearly do represent some of the final sediments deposited prior to extinction of the lake.

Intercalated within the youngest siltstone remnants are numerous mafic and silicic tephra layers $1-50 \mathrm{~mm}$ thick, absolute ages of which would place time constraints on final stages of the lake. At seven scattered locations (fig. 20), we have logged, collected, and analyzed tephra layers enclosed in uppermost silt sections at elevations that range from $2,084 \mathrm{~m}$ to $2,115 \mathrm{~m}$ asl. Each silt section (fig. 21) has between 1 and 21 ash layers, most of them mafic and 1-30 mm thick, but several silicic ash layers are $10-50 \mathrm{~mm}$ thick. Virtually all consist of fine to coarse ash, lacking lapilli, and most represent primary fallout.

The sites (fig. 20) are as follows. (1) BC: An 18-m-high silt exposure (UTM 450/729) on the north-facing slope of knoll 2096, on the east bank of the Owens River, $700 \mathrm{~m}$ south of the Benton Crossing bridge. We sampled 12 mafic ash layers and three silicic ones, including the paleomagnetically excursional ash, LV-III, discussed below. (2) ORB: A 16-m-high cutbank on the west side of the Owens River (UTM 415/769), $5 \mathrm{~km}$ north of Cashbaugh Ranch, exposes 12 ash layers, most containing hornblende and biotite; a few are probably reworked. The 6-m silt section grades up into a 2.5-m sand-richer shoreface interval with reworked lenses of early rhyolite pumice. The top $7.5 \mathrm{~m}$ of the section is fluviolacustrine sandy pebble gravel. (3) NHC: An 8-m cutbank on the northwest side of lower Hot Creek meadows (UTM 412/749) contains as many as 8 mafic ash layers. (4) CBR: A 9-m-high cutbank at Cashbaugh Ranch (UTM 403/722) on the west side of Hot Creek is capped by alluvial gravel that overlies a 6-m-thick section of silt that contains at least 9 mafic ash layers and one silicic. (5) K2104: The northwest slope of silt knoll 2104 (UTM 447/7505), $1.5 \mathrm{~km}$ north of the Benton Crossing bridge, exposes 10 mafic ash layers. (6) K2099: The southwest slope of silt hill 2099 (UTM 460/739), $1.3 \mathrm{~km}$ northeast of the Benton Crossing bridge, exposes 3 mafic ash layers. Finally, (7) SHC: A 1-cm layer of pale-orange fine ash crops out at an elevation of 2,104 $\mathrm{m}$ in a low-relief ridge of white silt along the southeast margin of lower Hot Creek meadows (UTM 416/728). Microprobe analyses of these tephra layers inform the following inferences.

Near Benton Crossing, close to the center of siltstone outcrop (figs. 5, 20), Liddicoat and others (1998) recorded a closely spaced pair of geomagnetic polarity excursions, the clockwise virtual geomagnetic pole (VGP) paths of which closely resemble a similar pair identified in lacustrine silts at Pringle Falls, Oregon (events A and B of Herrero-Bervera and others, 1994). The 5-m-thick excursional interval at Pringle Falls is dated at 220-200 ka (Channell, 2006; Singer and others, 2008; Herrero-Bervera and Cañón-Tapia, 2012). At Benton Crossing, the two-loop excursional interval is $\sim 1.3 \mathrm{~m}$ thick and lies near the top of a siltstone knoll $\sim 18 \mathrm{~m}$ high. A 2-cm-thick pinkish-orange silicic ash layer (LV-III of Liddicoat, 1990) is intercalated within the silt section (fig. 22), $\sim 30 \mathrm{~cm}$ above the base of the excursional interval. Tentative correlations of this hypersthene-hornblende-plagioclase ash (LV-III) had earlier suggested eruptive ages ranging from 280 ka to $160 \mathrm{ka}$ (Liddicoat and Bailey, 1989; Liddicoat, 1990), but its Pringle Falls correlation and age are now better established (Liddicoat and others, 1998). Ash LV-III, however, was chemically correlated not with pumice layer $\mathrm{D}$ at the base of the Pringle Falls excursion in Oregon but with ash layer E, which lies $\sim 42 \mathrm{~cm}$ higher in the excursional section (HerreroBervera and others, 1994). The $211 \pm 13 \mathrm{ka}$ age given by Singer and others (2008) is for Pringle Falls layer D, not E. If lacustrine silt were deposited at an average rate of $0.3 \mathrm{~mm} / \mathrm{yr}$, the $42 \mathrm{~cm}$ between $\mathrm{D}$ and $\mathrm{E}$ represents $\sim 1,400$ years, and the $1.6 \mathrm{~m}$ of silt that overlies ash LV-III at Benton Crossing (fig. 22) represents $\sim 5,300$ years. If the $211 \pm 13 \mathrm{ka}$ age for layer $\mathrm{D}$ is accurate, it can thus be inferred that the topmost silt preserved at the Benton Crossing knoll was deposited sometime between $217 \mathrm{ka}$ and $191 \mathrm{ka}$. An unknown thickness of silt has been eroded from the knoll top.

A cutbank bluff $\sim 16 \mathrm{~m}$ high along the right (southwest) bank of Owens River, $4.6 \mathrm{~km}$ northwest of Benton Crossing (ORB; fig. 20) exposes $\sim 6 \mathrm{~m}$ of lake silt overlain by $\sim 10 \mathrm{~m}$ of shoreface sand and post-lake fluvio-lacustrine sand and gravel. The top of the exposed section is at $\sim 2,107 \mathrm{~m}$ asl, and its base is at $\sim 2,091 \mathrm{~m}$, similar in elevation to the top of the Benton Crossing silt section. Most of the 11 ash layers collected in the bluff silt section are rhyolitic, contain biotite and hornblende, and are well correlated by microprobe mineral analyses (fig. 23 ) with the 150-ka West Moat Coulee (unit rwm of Hildreth and others, 2014), the vent for which is marked by a pumicerich ejecta ring $17 \mathrm{~km}$ west of the bluff. The microprobe data exclude correlation with all other postcaldera Long Valley rhyolites (figs. 20,23) and with silicic units erupted at Mammoth Mountain (fig. 23). The data for the ORB section thus require that silt deposition along the lake axis persisted until a time slightly after the set of 150-ka ashfalls.

Two layers ( $2-5 \mathrm{~cm}$ thick) of reworked rhyolite pumice granules were exposed in July 2014 in a temporary trench excavated at the county dump (UTM 429/719) $2.3 \mathrm{~km}$ southwest of the Benton Crossing bridge. Beneath $\sim 3 \mathrm{~m}$ of postlake alluvium, the trench exposed the topmost $2 \mathrm{~m}$ of white laminated lake silt, which hosted the thin pumice-slurry layers. The pumice likewise correlates chemically and mineralogically with that of the 150-ka West Moat Coulee, thus confirming that lake-silt sedimentation persisted until that time but not much longer.

Apart from the hornblende-biotite tephras at the ORB and dump sections, most of the ash layers logged in figure 21 are basaltic, with olivine their principal phenocryst. A few layers are intermediate in composition, contain only plagioclase, orthopyroxene, and amphibole (unlike any volcanic units in the region), and were probably dispersed from arc sources far away. In and near Long Valley Caldera, we mapped and ${ }^{40} \mathrm{Ar}{ }^{39} \mathrm{Ar}$-dated as many as 25 mafic eruptive units (lavas and scoria cones, $\sim 235-92 \mathrm{ka}$ ) potentially contemporaneous with Long Valley Lake (Hildreth and others, 2014), and we 
Table 1. U-Th isotopic data and ages for Long Valley tufas.

[All isotope ratios are activity ratios. Uncertainties are given at 1 standard deviation $(1 \sigma)$. Uncorrected ages are calculated without correction for $U$ and Th from detritus. Corrected ages are calculated assuming detritus with $\left({ }^{232} \mathrm{Th} /{ }^{238} \mathrm{U}\right)=1.2 \pm 0.6$, $\left({ }^{230} \mathrm{Th} /{ }^{238} \mathrm{U}\right)=1.0 \pm 0.1$, and $\left({ }^{234} \mathrm{U} /{ }^{238} \mathrm{U}\right)=1.0 \pm 0.1$. Decay constants are those of Jaffey $(1971)$ for ${ }^{238} \mathrm{U}$ and Cheng and others $(2013)$ for ${ }^{230} \mathrm{Th}$ and ${ }^{234} \mathrm{U}$. Initial ${ }^{234} \mathrm{U} /{ }^{238} \mathrm{U}$ ratios are back-calculated from measured ratios and corrected ages. Analyses by W. Sharp at Berkeley Geochronology Center. Sample locations discussed in text. mg, milligram; ppb, parts per billion, \%err, percent error]

\begin{tabular}{|c|c|c|c|c|c|c|c|}
\hline Sample name & $\begin{array}{c}\text { Sample } \\
\text { weight (mg) }\end{array}$ & $\mathbf{U}(\mathbf{p p b})$ & \multicolumn{2}{|c|}{${ }^{232} \mathrm{Th}$ (ppb) } & $\left({ }^{230} \mathrm{Th} /{ }^{232} \mathrm{Th}\right)$ & $\begin{array}{c}\left({ }^{232} \mathrm{Th} /{ }^{238} \mathrm{U}\right) \pm 1 \sigma \\
\% \text { err }\end{array}$ & \\
\hline M-997-1 & 100.71 & 768 & \multicolumn{2}{|c|}{161} & 13.60 & $0.07967 \pm 0.21$ & \\
\hline M-997-2 & 102.65 & 736 & \multicolumn{2}{|c|}{138} & 15.65 & $0.07143 \pm 0.16$ & \\
\hline M-1000-1 & 101.01 & 667 & \multicolumn{2}{|c|}{237} & 7.99 & $0.134946 \pm 0.13$ & \\
\hline M-1000-2 & 101.22 & 706 & \multicolumn{2}{|c|}{225} & 8.79 & $0.12098 \pm 0.14$ & \\
\hline M-1029B-1 & 99.39 & 762 & \multicolumn{2}{|c|}{556} & 3.80 & $0.27631 \pm 0.13$ & \\
\hline M-1029B-2 & 100.68 & 761 & \multicolumn{2}{|c|}{616} & 3.45 & $0.30663 \pm 0.12$ & \\
\hline Sample name & $\begin{array}{c}\left({ }^{230} \mathrm{Th} /{ }^{238} \mathrm{U}\right) \pm 1 \sigma \\
\% \text { err }\end{array}$ & \multicolumn{2}{|c|}{$\begin{array}{c}\left({ }^{234} \mathrm{U} /{ }^{238} \mathrm{U}\right) \pm 1 \sigma \\
\% \text { err }\end{array}$} & \multicolumn{2}{|c|}{$\begin{array}{l}\text { Uncorrected age } \\
(\mathrm{ka}) \pm \operatorname{error}(1 \sigma)\end{array}$} & $\begin{array}{l}\text { Corrected age } \\
(k a) \pm \text { error }(1 \sigma)\end{array}$ & $\begin{array}{c}\text { Initial }\left({ }^{234} \mathrm{U} /{ }^{238} \mathrm{U}\right) \pm \\
\text { error }(1 \sigma)\end{array}$ \\
\hline M-997-1 & $1.0836 \pm 0.12$ & \multicolumn{2}{|c|}{$1.1053 \pm 0.09$} & \multicolumn{2}{|c|}{$327.6 \pm 2.9$} & $322 \pm 14$ & $1.280 \pm 0.015$ \\
\hline M-997-2 & $1.1179 \pm 0.11$ & \multicolumn{2}{|c|}{$1.1137 \pm 0.08$} & \multicolumn{2}{|c|}{$377.5 \pm 3.9$} & $372 \pm 19$ & $1.346 \pm 0.017$ \\
\hline M-1000-1 & $1.0783 \pm 0.15$ & \multicolumn{2}{|c|}{$1.1282 \pm 0.08$} & \multicolumn{2}{|c|}{$281.3 \pm 2.0$} & $271 \pm 15$ & $1.310 \pm 0.026$ \\
\hline M-1000-2 & $1.0633 \pm 0.13$ & \multicolumn{2}{|c|}{$1.1303 \pm 0.08$} & \multicolumn{2}{|c|}{$263.1 \pm 1.5$} & $254 \pm 12$ & $1.297 \pm 0.023$ \\
\hline M-1029B-1 & $1.0499 \pm 0.14$ & \multicolumn{2}{|c|}{$1.1209 \pm 0.09$} & \multicolumn{2}{|c|}{$260.8 \pm 1.6$} & $239 \pm 27$ & $1.307 \pm 0.060$ \\
\hline M-1029B-2 & $1.0573 \pm 0.17$ & \multicolumn{2}{|c|}{$1.1225 \pm 0.07$} & \multicolumn{2}{|c|}{$266.2 \pm 1.8$} & $241 \pm 31$ & $1.324 \pm 0.070$ \\
\hline
\end{tabular}

analyzed olivine, Fe-Ti oxides, and clinopyroxene from all the units by electron microprobe. Although the microprobe data suggest correlations among various tephras in the seven silt sections (fig. 24), no convincing matches were identified among the numerous mafic ashes and the 25 mafic lavas and ejecta cones nearby.

From this disappointing result, we infer that virtually all the mafic tephras were deposited in the lake before eruption of any mafic lavas exposed in the vicinity, the oldest exposed lava having an age of $\sim 190 \mathrm{ka}$. The inference is consistent with the $211 \pm 13$ ka geomagnetically excursional interval atop the ash-rich silt section at Benton Crossing (figs. 21, 22). One lava-tephra correlation in which we do have confidence is between ash M-769 and two of the most deeply buried basaltic lava flows in the caldera's west moat (figs. 21, 24). These lavas were sampled in the Inyo-4 drillcore at depths of $1,046 \mathrm{ft}$ and 1,076 ft (Eichelberger and others, 1988), and the former yielded a ${ }^{40} \mathrm{Ar} /{ }^{39} \mathrm{Ar}$ age of $233 \pm 4 \mathrm{ka}$ (Hildreth and others, 2014). Another good correlation is between a set of mafic tephras sampled in five of the silt sections (fig. 21, circled in red and green) and the deepest mafic lava flow in drillcore OH-1 (fig. 5). The undated lava (50.3 percent $\left.\mathrm{SiO}_{2}\right)$ is lowest in a stack of $\sim 10$ mafic flows penetrated by the well, and it lies $\sim 125 \mathrm{~m}$ below a multi-flow mafic unit that was Ar-dated at 172-186 ka (unit mcl, fig. $6 B$ of Hildreth and Fierstein, 2016); it rests on a sedimentary section that in turn overlies the early rhyolite. These correlations are consistent with the inference that all or most of the mafic tephras intercalated with exposed silts of Long Valley Lake predate eruption of the Pleistocene mafic units exposed in or near the caldera.
In summary, ice-rafted erratics dropped on early rhyolite and then resurgently uplifted provide evidence for a large lake in early postcaldera time; lake deposits overlie moat rhyolite lavas that erupted $\sim 570 \mathrm{ka}$ and $362-329 \mathrm{ka}$; tufa formed $\sim 80 \mathrm{~m}$ below the southeastern highstand shoreline around $250 \mathrm{ka}$ and $\sim 40$ m below a shoreline at the foot of the caldera's north wall around $350 \mathrm{ka}$; tephras intercalated with some of the youngest lake silts correlate with a paleomagnetic excursion $\sim 211 \mathrm{ka}$ and with moat lavas that erupted $\sim 233 \mathrm{ka}$ and $\sim 150 \mathrm{ka}$. Lake sediment occurs on a moat basalt dated at $\sim 180 \mathrm{ka}$ but not on another one nearby, which yields an age of $\sim 172 \mathrm{ka}$ and lies 50-60 m lower in elevation, suggesting initial spillover and lowering of the outlet threshold about then. The youngest lake silts preserved contain the 150-ka tephra, but moat basalts that give ${ }^{40} \mathrm{Ar} /{ }^{39} \mathrm{Ar}$ ages of about 130, 125, 103, 90-100, and $92 \mathrm{ka}$ (Hildreth and others 2014) show no evidence of wave erosion or lake sedimentation.

\section{Extinction of Long Valley Lake}

Long-lived Long Valley Lake, fed by several Sierran streams, must have begun to form soon after the 767-ka caldera-forming eruption, which left a depression that ultimately filled with $>700 \mathrm{~m}$ of sediments. Many of the early rhyolite lavas $(\sim 750-640 \mathrm{ka})$ retain lake-contact features such as wave-cut shoreline scarps, sheets of well-rounded shoreline gravel, indurated beds of pebbly sandstone, dense perlite, and ice-rafted Sierran erratics. A rhyolite lava flow in the caldera's 


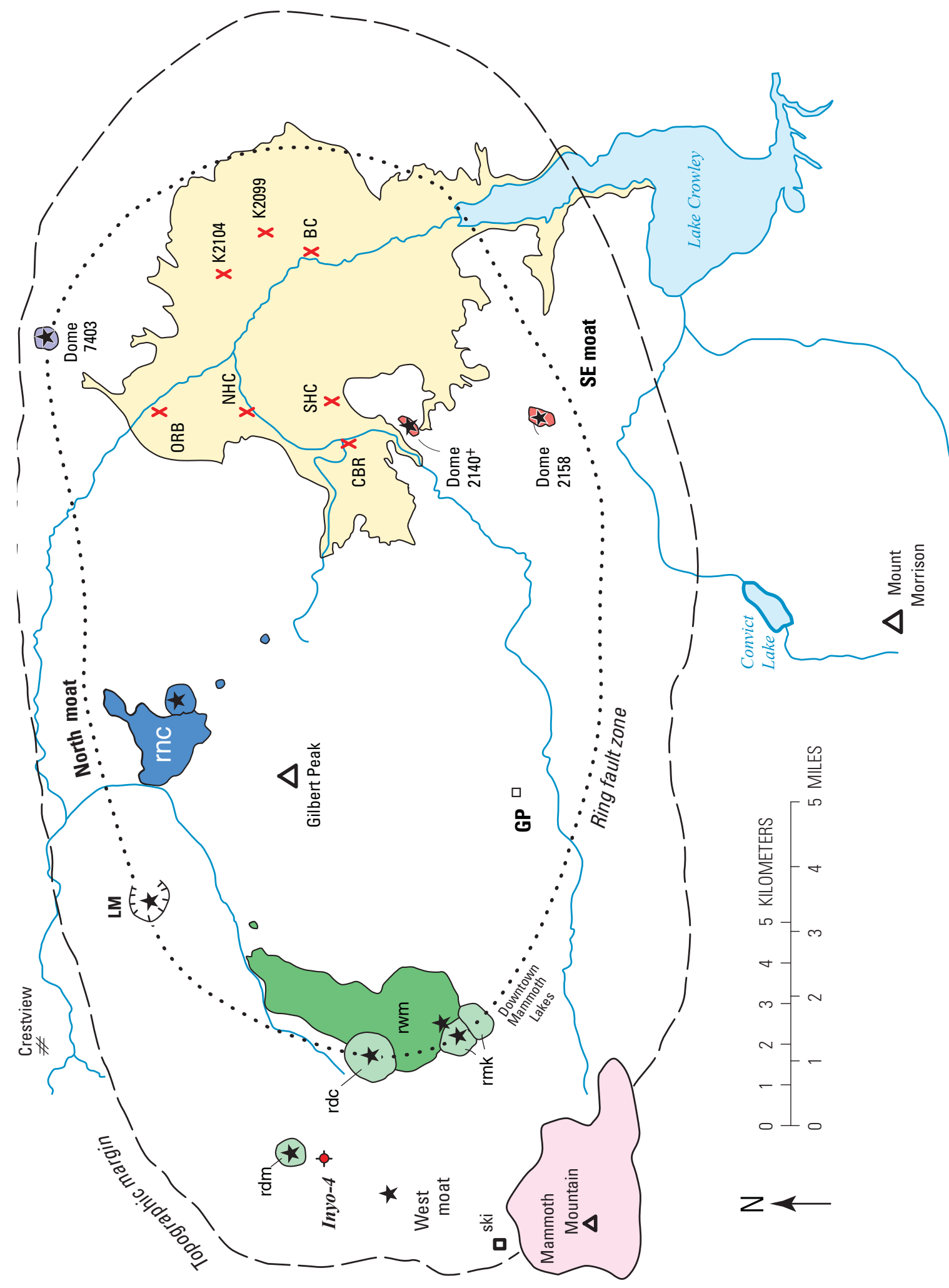

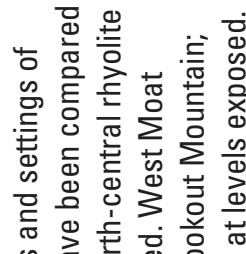

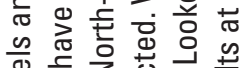

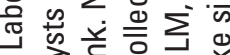

穴它它们

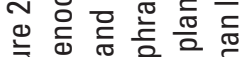

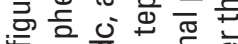

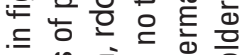

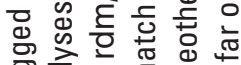

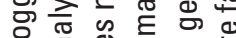

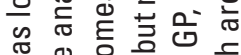

过 응 응

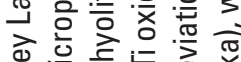

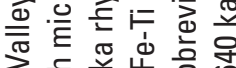

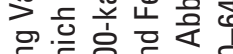

독은

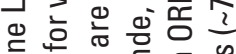

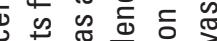

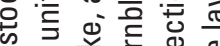

远

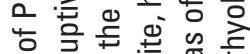

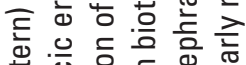

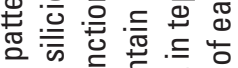

उั

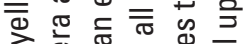

은 $\frac{\pi}{5} \frac{\pi}{\pi} \frac{0}{0}$

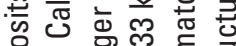

㐨

돈

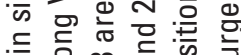

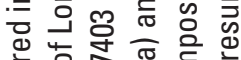

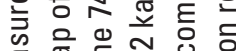

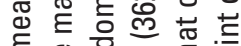

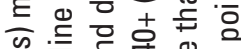

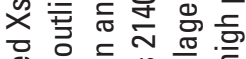

递 ᄃ

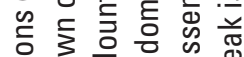

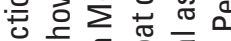

क क F 要

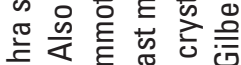

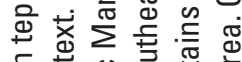

可产. 总垔

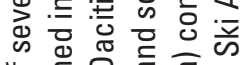

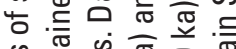

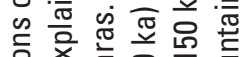

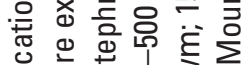

政这

次至的竞

ㄱำ

N

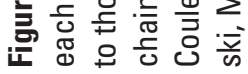




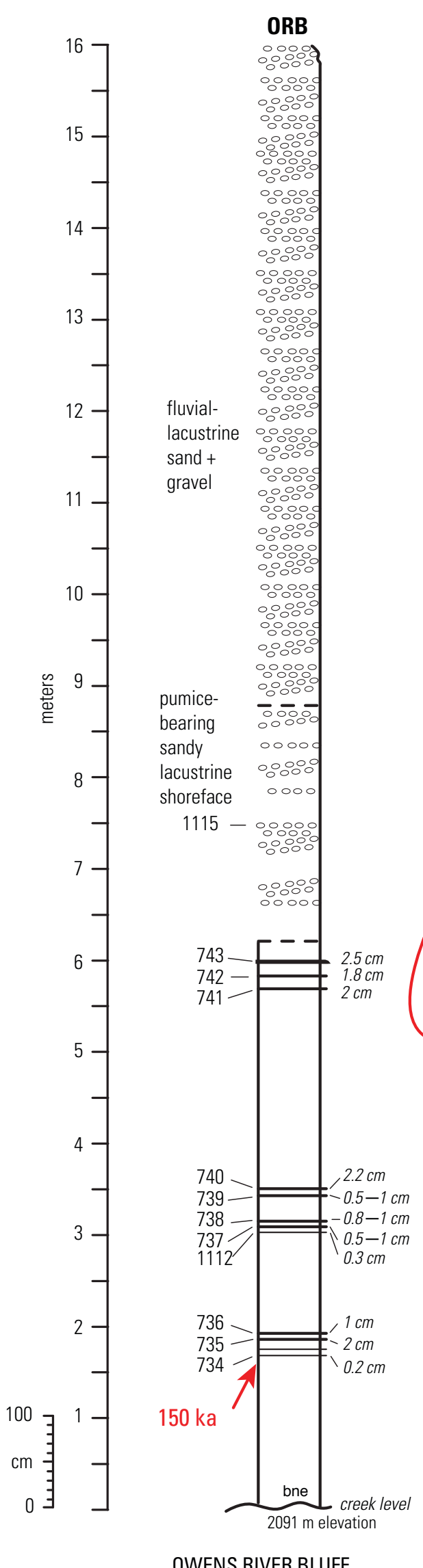

OWENS RIVER BLUFF

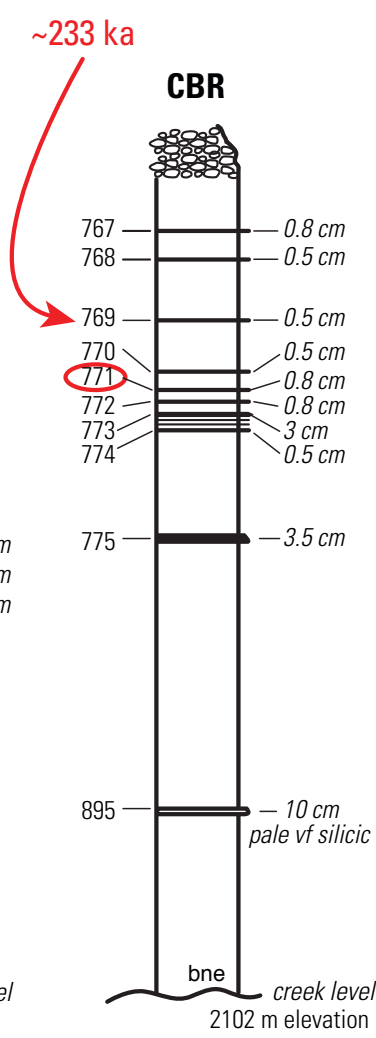

CASHBAUGH RANCH
Figure 21. Logs of the seven tephra sections located in figure 20. Ages in red are discussed in text. Tephra sample numbers circled in red, blue, and green indicate correlations among ash layers in different silt sections, as identified by same colors in plots of figure 24. Those circled in red and green also correlate with an unexposed basaltic lava flow, undated but older than $190 \mathrm{ka}$, sampled at a depth of $317 \mathrm{~m}$ in corehole $\mathrm{OH}-1$ (fig. 5 ; and fig. $6 B$ of Hildreth and Fierstein, 2016). Abbreviation "bne" means base not exposed. Pebble patterns at column tops represent postlake alluvial gravel that caps most silt exposures. Nearly all tephras in the Owens River Bluff (ORB) section (except M-737) contain hornblende and biotite, as do most moat rhyolite lavas (570-100 ka) at Long Valley. In the other six sections, biotite is absent, most tephras are mafic, and a few are intermediate (containing orthopyroxene and hornblende and presumed to be of Cascadian origin).

\section{NHC}

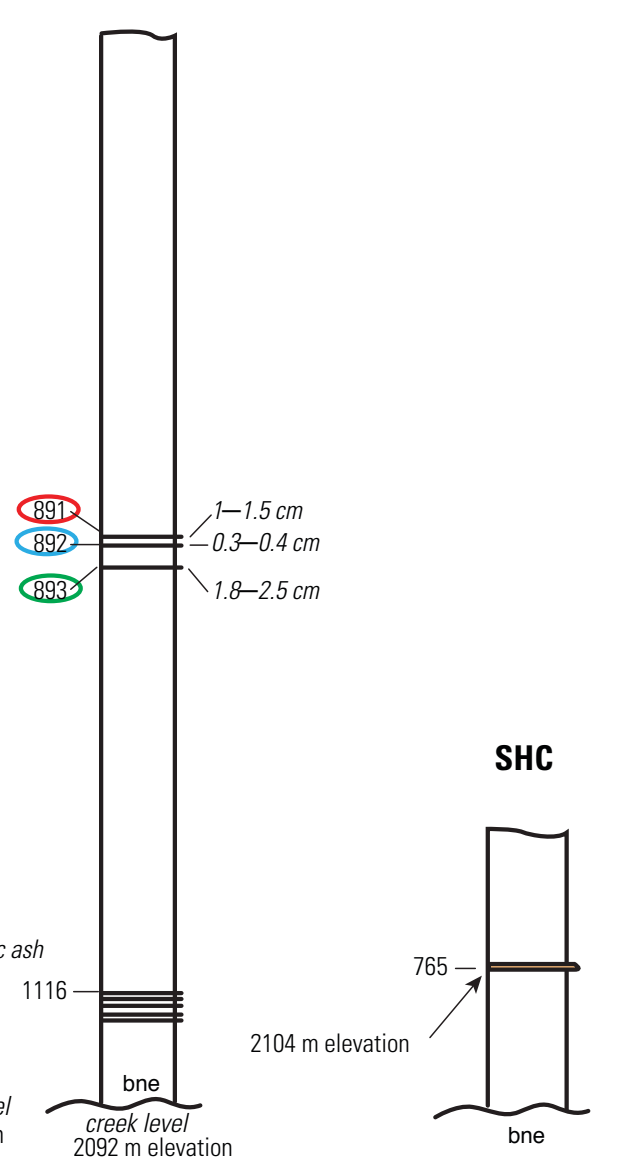

$N$ LOWER HOT CREEK

S. HOT CREEK MEADOW MEADOW 

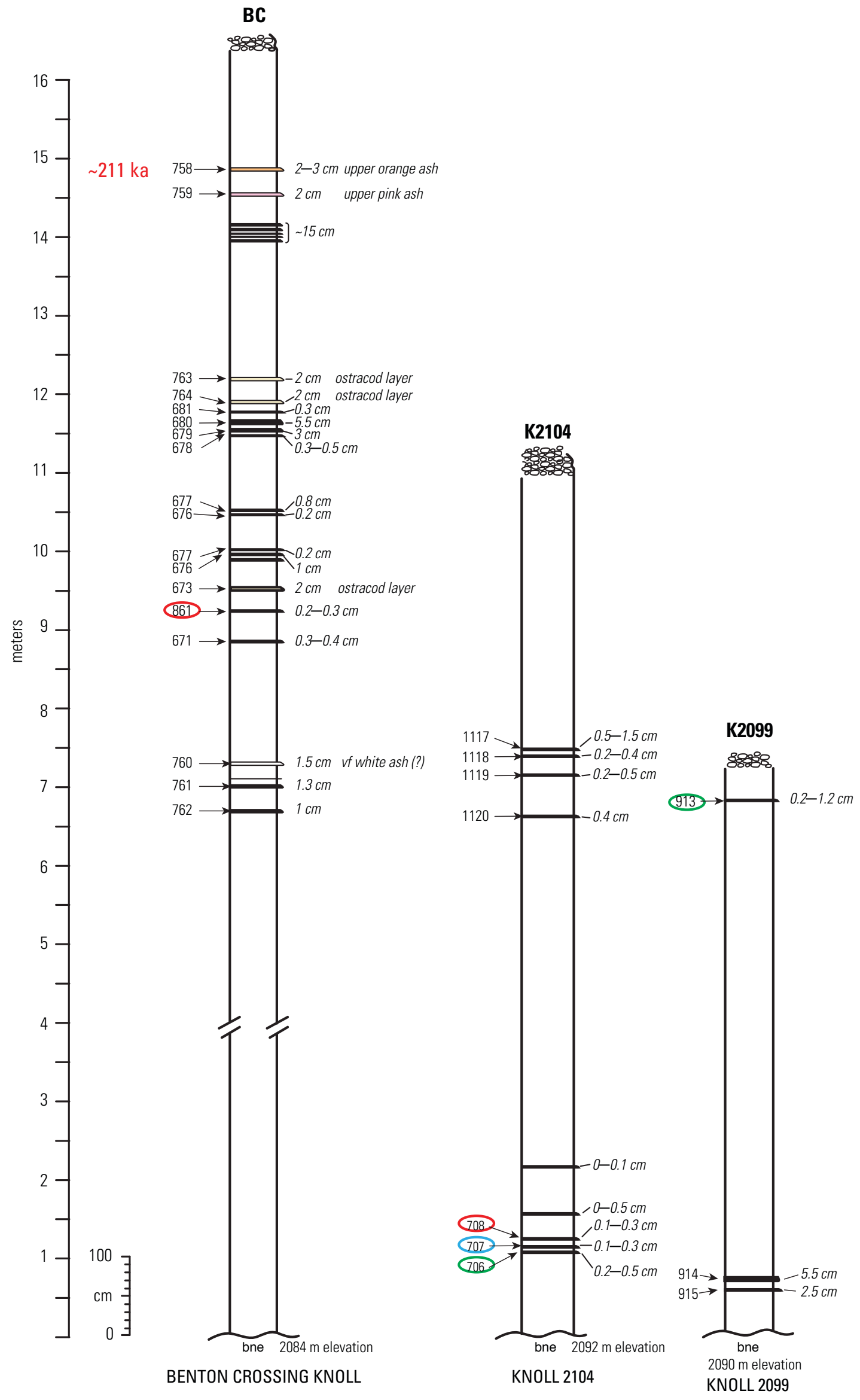


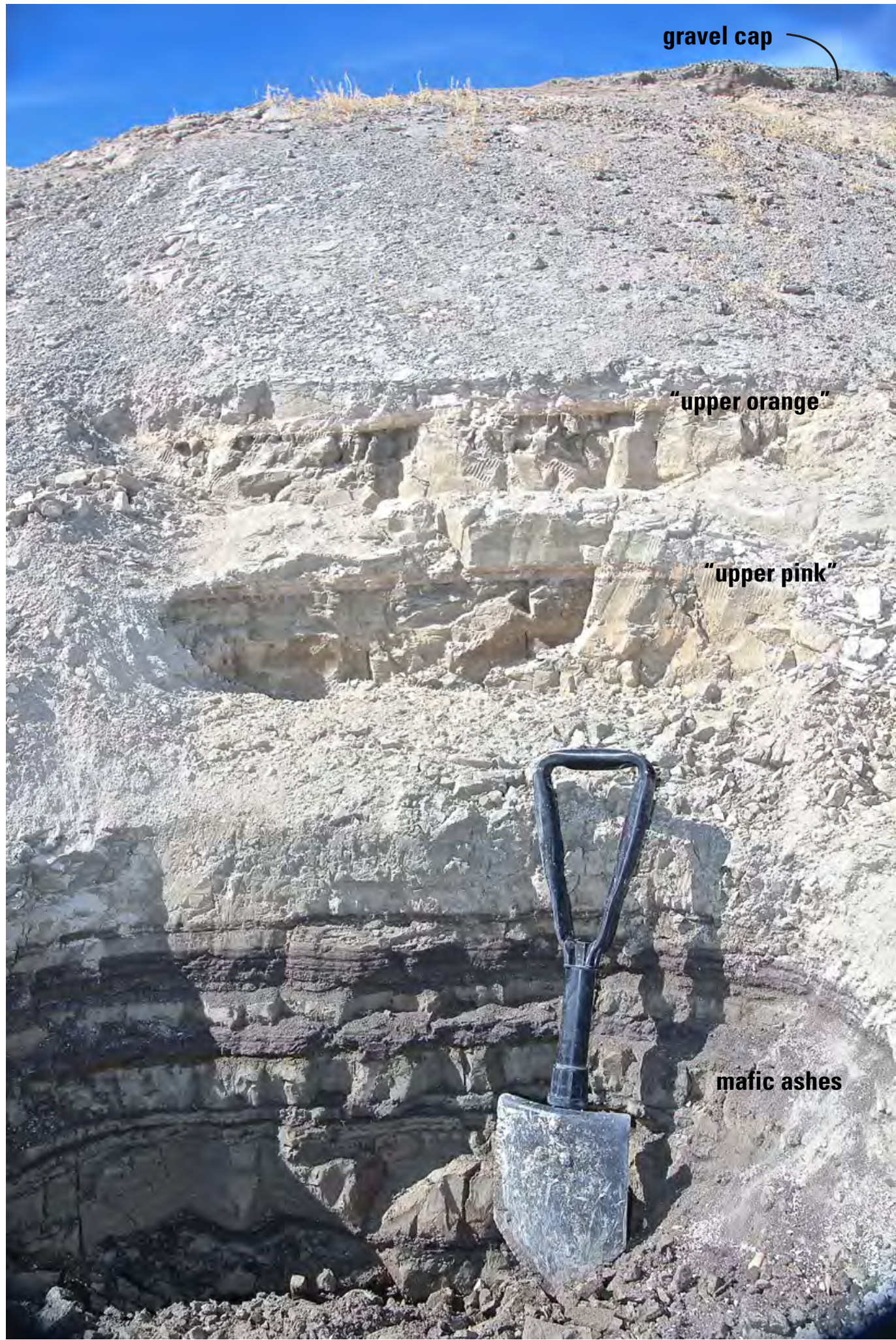

Figure 22. Ash layers intercalated in white silt near top of Pleistocene lacustrine exposure (section BC) on knoll 2096, just south of Benton Crossing bridge over Owens River. At center of image, two pinkish-orange orthopyroxene+hornblende-bearing silicic ash layers of presumed Cascadian origin, each $2 \mathrm{~cm}$ thick, are separated by $26 \mathrm{~cm}$ of silt. Top layer is "upper orange" and the second is "upper pink," as logged in figure 21 and plotted in figure 23. Uppermost layer is LV-III of Liddicoat and others (1998); it underlies $1.6 \mathrm{~m}$ of silt that extends to thin gravel capping on skyline, and it lies within a silt interval $50 \mathrm{~cm}$ thick that is paleomagnetically excursional (Liddicoat and Bailey, 1989). Shovel is $58 \mathrm{~cm}$ long. Beginning at shovel handle and extending for $\sim 7 \mathrm{~m}$ lower are no fewer than 19 basaltic and intermediate ash layers, each 1 to $5 \mathrm{~cm}$ thick (fig. 21), intercalated with diatom-and-ostracod-bearing silt. 

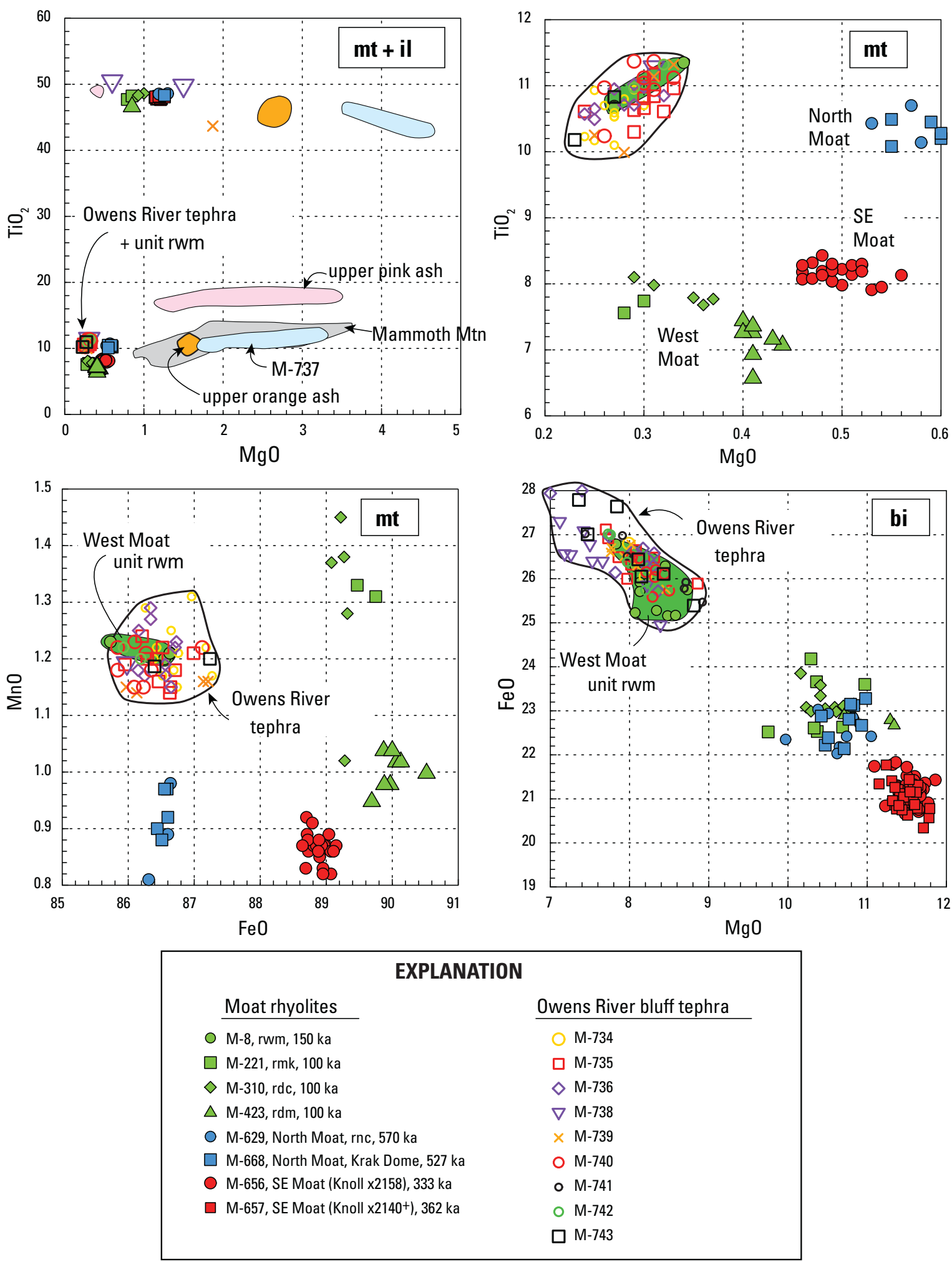

Figure 23. Plots of electron-microprobe data for magnetite (mt), ilmenite (il), and biotite (bi) phenocrysts from silicic tephra layers in lacustrine silt section exposed at Owens River bluff (section ORB; figs. 20, 21) compared with same phases from Pleistocene silicic lavas in Long Valley Caldera. Oxide contents in weight percent. Upper-right panel expands small (lower-left all-magnetite) part of upper-left panel. Except layer M-737, all tephra layers in section correlate with 150-ka West Moat Coulee (unit rwm). All are distinguishable from rhyolite lavas (fig. 20) of north-central rhyolite chain (rnc), southeast moat cluster, and 100-ka domes of west moat (rmk, rdc, rdm). Tephras labeled "upper orange" (LV-III of Liddicoat and others, 1998) and "upper pink" are those illustrated in figure 22, probably dispersed by rhyodacitic eruptions in the Cascade Arc. In upper-left panel, array labeled "Mammoth Mtn" represents magnetites from eight silicic effusive units on that edifice (Hildreth and others, 2014; Marcaida and others, 2014); the three colored fields for ilmenite (40-50 percent $\mathrm{TiO}_{2}$ ) are colored the same as counterparts of labelled fields for magnetite (7-19 percent $\left.\mathrm{TiO}_{2}\right)$. 
north moat (fig. 20; unit rnc of Hildreth and Fierstein, 2016), ${ }^{40} \mathrm{Ar} /{ }^{39} \mathrm{Ar}$ dated at $570 \pm 9 \mathrm{ka}$ by Simon and others (2014), retains sparse rounded gravels on its distal surface. In the southeast moat, the Hot Creek flow and several other rhyolitic lavas nearby (fig. 5; 362-329 ka; Mankinen and others, 1986; Heumann and others, 2002; Simon and others, 2014) all erupted into the lake and were subsequently partly covered by lake sediment. In the south moat, a mafic lava flow (unit mcl; $180 \pm 2 \mathrm{ka}$; Hildreth and others, 2014) surrounded by pebbly sandstone shows that the lake persisted until early MIS 6. No evidence has been found that the lake lasted much later than $\sim 150 \mathrm{ka}$, and, as presented above, much evidence suggests that it did not. Because drillhole data (Fournier, 1989) indicate no evidence of unconformity or dessication within (all but the basal $10 \mathrm{~m}$ of) the $700-\mathrm{m}$ section of lake sediments, we infer that the caldera lake persisted for about 600,000 years before its demise in MIS 6.

Owens Lake and Searles Lake, downstream from Long Valley Lake along the Owens River drainage system, each have extended drillcore records of alternating hydrologically open and closed Pleistocene conditions, but both were shown to have been fresh and intensely overflowing during the interval 170-120 ka (Bradbury, 1997; Smith and others, 1997; Smith, 2009). Regional evidence is thus consistent with inference of overflow at Long Valley in MIS 6.

If caldera-lake sedimentation began at $767 \mathrm{ka}$ and ended soon after $150 \mathrm{ka}$, the $696 \mathrm{~m}$ of sediment fully penetrated by drillhole 66-29 represents an average filling rate of $\sim 1.1 \mathrm{~mm} / \mathrm{yr}$. If hornblende and biotite crystals identified by Fournier (1989) at depths of 390-400 m in drillhole 66-29 were derived from the 570 ka rhyolites of the north-central chain (Bailey, 1989; Hildreth, 2004; Simon and others, 2014), this would suggest a pre- $570 \mathrm{ka}$ sedimentation rate of $1.5 \mathrm{~mm} /$ yr and a post- $570 \mathrm{ka}$ rate of $\sim 1.0 \mathrm{~mm} / \mathrm{yr}$ until the time of lake extinction at $\sim 150 \mathrm{ka}$. If hornblende and biotite reported by Lewis (1975) in sediments at depths of 185-190 m in corehole CH-1 represent the 362-329 ka rhyolites erupted nearby in the caldera's southeast moat, then a similar sedimentation rate of $\sim 1.0 \mathrm{~mm} / \mathrm{yr}$ through $\sim 150 \mathrm{ka}$ is again indicated. These are the principal occurrences of hornblende in the two deep drilling logs, and the two clusters of rhyolite just named are the only middle Pleistocene eruptive units in the Long Valley region that contain both hornblende and biotite. The apparently consistent sedimentation rate favors the correlations, but rare hornblende in sandy sediment at various additional depths in well 66-29 (Fournier, 1989) suggest alternatively that some of the hornblende could have been cleanly liberated from Mesozoic granitoids. Note that, if the 570-ka correlation is correct, then the lake floor was still $\sim 400 \mathrm{~m}$ lower than the spillpoint of the caldera depression after 200,000 years of sedimentation.

\section{Processes Leading to Overflow}

Processes likely to have contributed to overflow and thereby to ultimate extinction of the lake by downcutting of Owens Gorge include the following:
(1) Sediment, much of it derived from rhyolite tuffs, progressively filled the profound caldera depression, but it took more than half a million years to raise the lake level to its lowest threshold for overflow-at the outlet arm, which now leads into Owens Gorge. Scrutiny of the 700-m-thick sedimentary column penetrated by drilling (Fournier, 1989) suggested that the water column itself remained fairly shallow (generally $\leq 15 \mathrm{~m}$, but at times as deep as $50 \mathrm{~m}$ ) while prolonged sedimentation gradually raised its absolute elevation by $>700 \mathrm{~m}$.

(2) Southward tilting of the landscape east of the caldera gradually lowered the elevation of the threshold for overflow. Tectonic deformation in the area considered consists of at least three components. First, southward downwarping of the upper Volcanic Tableland (including the upper 10-km reach of Owens Gorge) toward the west-northwest-trending segment of the Round Valley Fault on the Sierran rangefront (figs. 1, 3). Second, uplift of the Glass Mountain region, raising the highstand shoreline at Wilfred Canyon (now at 2,335 m) $\sim 40 \mathrm{~m}$ higher than potential overflow thresholds at Watterson Canyon (2,293-2,297 m) that were never used. Taken together, these components have tilted the highstand shoreline $0.8^{\circ}-0.9^{\circ}$ southward, from Wilfred Canyon $(2,335 \mathrm{~m})$ to Little Round Valley $(2,100 \mathrm{~m})$ during the $\sim 175,000$-year interval since the lake receded from its highstand. (Recall, however, that a shrinking lake persisted until after $\sim 150 \mathrm{ka}$.) The $900 \mathrm{~m}$ of relief on the extensional Round Valley Fault near Rock Creek (figs. 2, 11, 19) suggests that total postcaldera tilting of the Bishop Tuff surface here (since $767 \mathrm{ka}$ ) is likely to have been substantially greater. Third, warping of the lower Volcanic Tableland southeastward toward Owens Valley and southwestward toward Round Valley (fig. 3) strongly influenced the gradients of Owens River and Rock Creek downstream from the granodiorite paleoridge.

(3) Secular erosion of the surface of the Bishop Tuff took place in the vicinity of the outlet arm. Stripping of $50-80 \mathrm{~m}$ of poorly to moderately welded ignimbrite from the lake-facing slope of the uppermost Volcanic Tableland contributed to lowering the threshold. Nearby, as much as $200 \mathrm{~m}$ of Bishop Tuff was eroded from Little Round Valley (fig. 19), providing a potentially alternative overflow route (to Rock Creek via Crooked Creek) that was never used, as explained above in the section "Erosion of the Ignimbrite Surface."

(4) The 10-km-wide resurgent uplift has raised the Bishop Tuff and early postcaldera rhyolites ( $750-640 \mathrm{ka})$ by $\sim 400 \mathrm{~m}$ in the west-central part of the caldera (Bailey, 1989; McConnell and others, 1995; Hildreth, 2004) but only after many of the rhyolites had been affected by erosion, sedimentation, and perlitization in the caldera lake. The resurgence necessarily contributed to raising the lake level by diminishing its area. Fault displacements across the resurgent structure affect basaltic lavas as young as $125 \mathrm{ka}$ (Hildreth and Fierstein, 2016), and an additional $\sim 80 \mathrm{~cm}$ of uplift has taken place since 1980 (Langbein, 2003), but it seems likely (though not proven) that much of the resurgent uplift had occurred before $\sim 500 \mathrm{ka}$. A rhyolite coulee (unit rnc; fig. 20) 

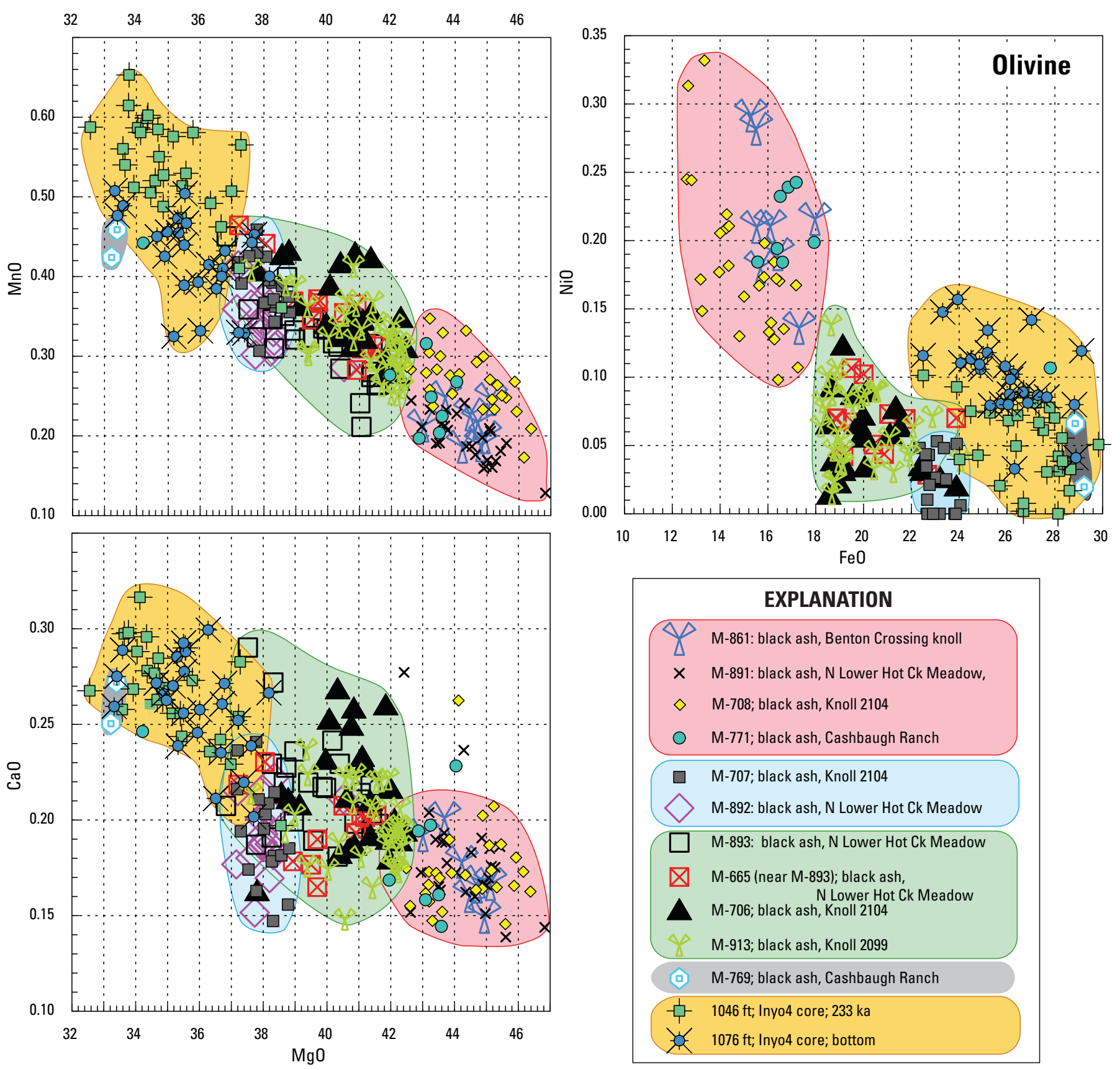

Figure 24. Chemical plots of electron-microprobe data for olivine phenocrysts in several mafic tephras intercalated in exposures of lacustrine silt, as logged in figure 21. Oxide contents in weight percent. Fields enclosed by red, blue, and green lines suggest correlations among ash layers from different silt sections, as identified by same colors in logs of figure 21. Fields colored yellow enclose data for two basalt samples from Inyo-4 core (Eichelberger and others, 1988; Hildreth and others, 2014) that have olivine compositionally similar to that in tephra sample M-769. 
flowed steeply down the north flank of the resurgent uplift at $570 \mathrm{ka}$, descending

$\sim 180 \mathrm{~m}$ to the floor of the caldera's north moat. There is no evidence that the lake had overflowed or approached its threshold that early.

(5) The Hot Creek flow and several associated rhyolite lavas (Bailey, 1989; Hildreth, 2004) that erupted into the lake in the southeast moat during the interval $\sim 362-329$ ka displaced as much as $1.5 \mathrm{~km}^{3}$ of lake water, presumably helping to raise lake level. No evidence is known to suggest overflow at that time.

(6) The Tahoe glaciation of MIS 6, which had greater effect on Sierran geomorphology than any climatic episode since the Sherwin glaciation (MIS 22), must have deepened Long Valley Lake, helping to raise lake level toward its threshold. Earlier pluvial episodes may have likewise increased sedimentation and deepening, but not until MIS 6 was lake level close enough to its sill to attain overflow.

(7) Differential compaction of the thick ignimbrite that filled the precaldera channel of the Owens River would have produced a broad, shallow swale across the surface of the Bishop Tuff. Such compactional swales on ignimbrite surfaces commonly collect subsequent runoff, promoting establishment of new streams directly above the courses of their buried predecessors (as in the Valley of Ten Thousand Smokes at Katmai; Hildreth and Fierstein, 2012). Owens River channels filled by the Bishop Tuff (fig. 11) included (a) the extracaldera reach of the outlet arm west of the dam, at least $3 \mathrm{~km}$ long and now drowned by Lake Crowley reservoir; (b) the 8-kmlong east-trending reach between the dam and the basalt-filled segment of the granodiorite gorge; (c) the distal reach of the granodiorite gorge, which extended at least $1 \mathrm{~km}$ downstream from the basalt blockage and potentially much farther down the Volcanic Tableland where the basement is still wholly concealed by the welded ignimbrite; and (d) the inferred postbasalt pre-Sherwin channel that was diverted southwest by the basaltic shield from the Z-bend to Rock Creek. Of the four, only the last (d) failed to localize reincision of a new gorge in the Bishop Tuff, probably because that reach had earlier been filled by Sherwin Till. The diverted reach (fig. 11) is, however, overlain by a shallow erosional valley across the weakly welded ignimbrite surface from test hole 1-X to Rock Creek.

The original depth of such compactional swales cannot be measured because the erosion they concentrated led to their own destruction as the new gorge was excavated. Across a wider area, the surface of the Bishop Tuff capping the ridges west and north of Little Round Valley slopes $1^{\circ}-3^{\circ}$ NNE. toward the head of Owens Gorge (fig. 15C). North of Owens Gorge, as discussed above, the ignimbrite surface (and highstand shoreline) slopes $0.8-0.9^{\circ} \mathrm{S}$. toward the gorge. Because of irregular surface erosion and the regional post-lake southward downwarping toward the outlet arm, however, evaluating what component of those opposing slopes might represent differential ignimbrite compaction across the precaldera Owens River channel it filled is problematic or impossible. Nonetheless, several density profiles of the ignimbrite that forms the walls of Owens Gorge illustrate wide ranges in degrees of compaction and welding (figs. 7, 11 of Wilson and Hildreth, 2003). Adjacent to both the 8-km-long upstream reach and the short reach just downstream of the basalt blockage, much of the Bishop Tuff is poorly welded with densities in the range $1,200-1,600 \mathrm{~kg} / \mathrm{m}^{3}$, whereas denser welded zones on gorge walls are in the range $1,800-2,000 \mathrm{~kg} / \mathrm{m}^{3}$. These large density differences are permissive of tens of meters of differential compaction in ignimbrite sections 100-200 m thick.

Long before the caldera lake approached its threshold for overflow, surface runoff westward from the drainage divide into the caldera depression would have concentrated erosion most intensively along the compactional swale, thus reestablishing a channel above the ignimbrite-buried reach of the precaldera Owens River. Deepening of the swale into the sharp gorge cut in the Bishop Tuff could have been accomplished by plunge-pool erosion at the toe of an intermittent waterfall over an eastward-retreating headcut scarp and by seepage erosion at the toe of the retreating scarp. Basal nonwelded ignimbrite and subjacent rubbly permeable basalt would have been readily eroded, undermining the overlying scarp of welded ignimbrite, which, being highly fractured and block-jointed, has always been susceptible to block failure and slab spalling from the gorge walls, then as now.

As the level of Long Valley Lake approached its threshold, lake water began to invade and erode the west-flowing stream channel, progressively lengthening the inlet that ultimately became its elongate outlet arm (much like the arm of Lake Crowley today; fig. 25). Well-rounded lakeshore gravels and indurated pebbly sandstones are preserved on both sides of the former inlet for 2-3 km west of modern Long Valley Dam and for at least $2.4 \mathrm{~km}$ east of the dam, showing that a narrow arm of the Pleistocene lake had grown eastward along the swale-initiated channel, past the Z-bend, and potentially as far as the basement ridge $\sim 7 \mathrm{~km}$ east of the dam (figs. 3 , 11). Lack of lakeshore sediments along the reach of the gorge rim from just east of the Z-bend to the basement ridge reflects eastward rise of the rim to as high as 2,230 m, well above the 2,158-m highstand along the inlet. East of the Z-bend, the developing (fjord-like) inlet was confined below the rim, between steep walls of welded Bishop Tuff. Lakeshore erosion at the advancing head of the inlet would have become a major contributor to reexcavation of the gorge, augmenting headward (eastward) stream erosion, but it could have become important only after the lake approached its threshold, following the half-million years of sedimentation that filled the 700-m-deep caldera depression.

It may be helpful in following this analysis to refer ahead to the multi-stage illustration provided as a summary in figure 26.

Conversion of the swale into a linear arm of the lake is thus inferred to have been accomplished first by ephemeral surface runoff that drained westward, lowering the calderafacing ignimbrite surface and reincising a gorge along the compactional swale, and second, much later, by lakeshore erosion at the advancing head of the inlet (fig. 25). If such an 
interpretation is correct, headward erosion indeed played an important role in reexcavating Owens Gorge, but its progress was not upstream from Owens Valley but eastward as the arm of Long Valley Lake advanced along the compactional swale. Sediments along the gorge rim are lacustrine, not fluvial. Above and just east of the dam, the calcite-cemented pebbly sandstone (beachrock), 3-4 m thick, that rims the gorge is plane-bedded, lacks fluvial lenses, and carries a pebble suite indistinguishable from the loose gravels mantling the adjacent lake terrace - dominantly metasedimentary with fewer rhyolitic and granitic clasts. The elongate inlet arm did not become an outlet arm until the granodiorite-basalt barrier was overtopped and lake level lowered by downcutting of an outlet stream, modern Owens River, that finally reestablished the gorge that had been abandoned in the Pliocene.

Long Valley Lake could not have overflowed before it filled sufficiently to invade the elongate inlet that soon thereafter became the outlet, the low point of the entire hydrographic basin. A hypothetically alternative outlet, via Little Round Valley to Rock Creek, was evidently never low enough during lifetime of the lake and was downwarped to its present lower elevation only in post-lake time. An outlet there would have obviated the need for cutting Owens Gorge.

Among the arguments against significant headward growth of the gorge upstream from Owens Valley are the scant rainfall, ready infiltration, and poor integration of dry arroyos on the arid Volcanic Tableland. Seasonal and intermittent overland flow to the headcut of the eastward-advancing fjordlike inlet must nonetheless have been important. The area of concern is the highest part of the Volcanic Tableland and is today subject to sporadically intense rainstorms. Modern annual precipitation ranges widely but can be double that on the lower tableland. At Mammoth Lakes, annual precipitation $(753 \mathrm{~mm})$ is four times that at Bishop airport $(173 \mathrm{~mm})$. Today, the upland area is pine forest and the lower tableland is sagebrush scrub (fig 14). Whenever the crestal area received significant rainfall, particularly during pluvial episodes, the compactional swale would have concentrated runoff toward the eastward-retreating headscarp.

The low gradient (fig. 13) and relatively linear course (excepting the Z-bend) of the gorge upstream of the basaltgranodiorite high are compatible with headward advance of the inlet eastward, whereas the meandering gorge downstream of the high (fig. 14) is unlikely to have been produced by $30 \mathrm{~km}$ of headward advance up the steep dry slope of the lower Volcanic Tableland. If Long Valley Lake had been captured solely by a 600,000 -year-long advance of the gorge headward from Owens Valley, no narrow lacustrine outlet arm several kilometers long need have developed at the time of the lake's highstand.

Three deep arroyos described in an earlier section, "Filling History of the Lake", were cut during pre-highstand time into the nonindurated Glass Mountain pyroclastic fan, east of the lake. All extend $\sim 8 \mathrm{~km}$ east of the lake's center from headwaters elevations $>900 \mathrm{~m}$ above the original lake floor. Restricted in catchment area and incised by ephemeral runoff into treeless barren tuff, the arroyos probably developed largely by headward erosion, providing analogs for the headward swale excavation proposed here for the outlet arm.

\section{Overflow and Draining of Long Valley Lake}

The high point of the basalt-granodiorite paleoridge on the gorge walls has an elevation of $2,140 \mathrm{~m}$, which is $\sim 20 \mathrm{~m}$ lower than the highest shoreline sediments on the rim of the outlet arm $(\sim 2,158 \mathrm{~m}), \sim 8 \mathrm{~km}$ upstream. Draping over this basement high, the Bishop Tuff is only $40 \mathrm{~m}$ thick, but it thickens to $>100 \mathrm{~m}$ both upstream and downstream within $1 \mathrm{~km}$ (fig. 13). The highest reach of the gorge rim (which everywhere consists of Bishop Tuff) is at 2,230 m on the weakly defined north-south drainage divide (figs. 3, 5, 11, 13), which crosses the gorge $\sim 3 \mathrm{~km}$ downstream from the Z-bend and $\sim 5 \mathrm{~km}$ upstream from the basement high point. As the upper gorge runs roughly eastward, the amount of post-lake southward tilting of the shoreline and of the gorge rim is likely to have been similar.

Eastward advance of the inlet along the compactional swale had to remove ignimbrite that widely rose $40 \mathrm{~m}$ and as much as $70 \mathrm{~m}$ above the highest known lake level along the inlet. The unknown original depth of the swale may have reduced this demand by 10-20 $\mathrm{m}$. Although the top of the granodiorite-basalt barrier was lower by $\sim 20 \mathrm{~m}$ than the lake level of the advancing inlet, the key to understanding reintegration of Owens Gorge is to know how the excess 40-70 m of ignimbrite above lake level was eroded from an $8-\mathrm{km}$ reach of the gorge.

The exposed top of the basalt-granodiorite high is today at 2,140 $\mathrm{m}$ on the left-bank wall of the gorge and at 2,100 m on the right-bank wall, dropping gradually upstream to $2,000 \mathrm{~m}$ on the gorge floor and steeply downstream to 1,920 $\mathrm{m}$ near power house \#1 (fig. 13). Eastward advance of the lake arm at 2,150-2,160 m could thus have taken place exclusively within the Bishop Tuff. Once overflow of the lake began, however, streamflow entrenchment would have soon cut into rubbly basalt, potentially accelerating gorge incision.

Lithologies of the basement rocks and the ignimbrite draping them are likely to have been important factors influencing progressive deepening of the gorge. Seepage through fractured granodiorite and rubbly basalt may have contributed to undermining the ignimbrite that filled the paleocanyon segments (that had been abandoned since the old gorge was blocked by the 3.3-Ma basaltic shield) on both flanks of the basement ridge. The Bishop Tuff has poorly welded basal zones 10-30 m thick exposed on both sides of the basement ridge. Unconsolidated Sherwin Till 20-35 m thick directly underlies the ignimbrite for $\sim 1.5 \mathrm{~km}$ downstream from the basement high point (fig. 15A). Moreover, along the downstream slope of the basement high, the upper $30 \mathrm{~m}$ of Bishop Tuff is merely sintered or poorly welded (density profile $\mathrm{E}$ of Wilson and Hildreth, 2003). On the upstream slope of the basement high, the upper $30-60 \mathrm{~m}$ of the ignimbrite is likewise only sintered or poorly welded $\left(1.4-1.85 \mathrm{~kg} / \mathrm{m}^{3}\right.$ and 


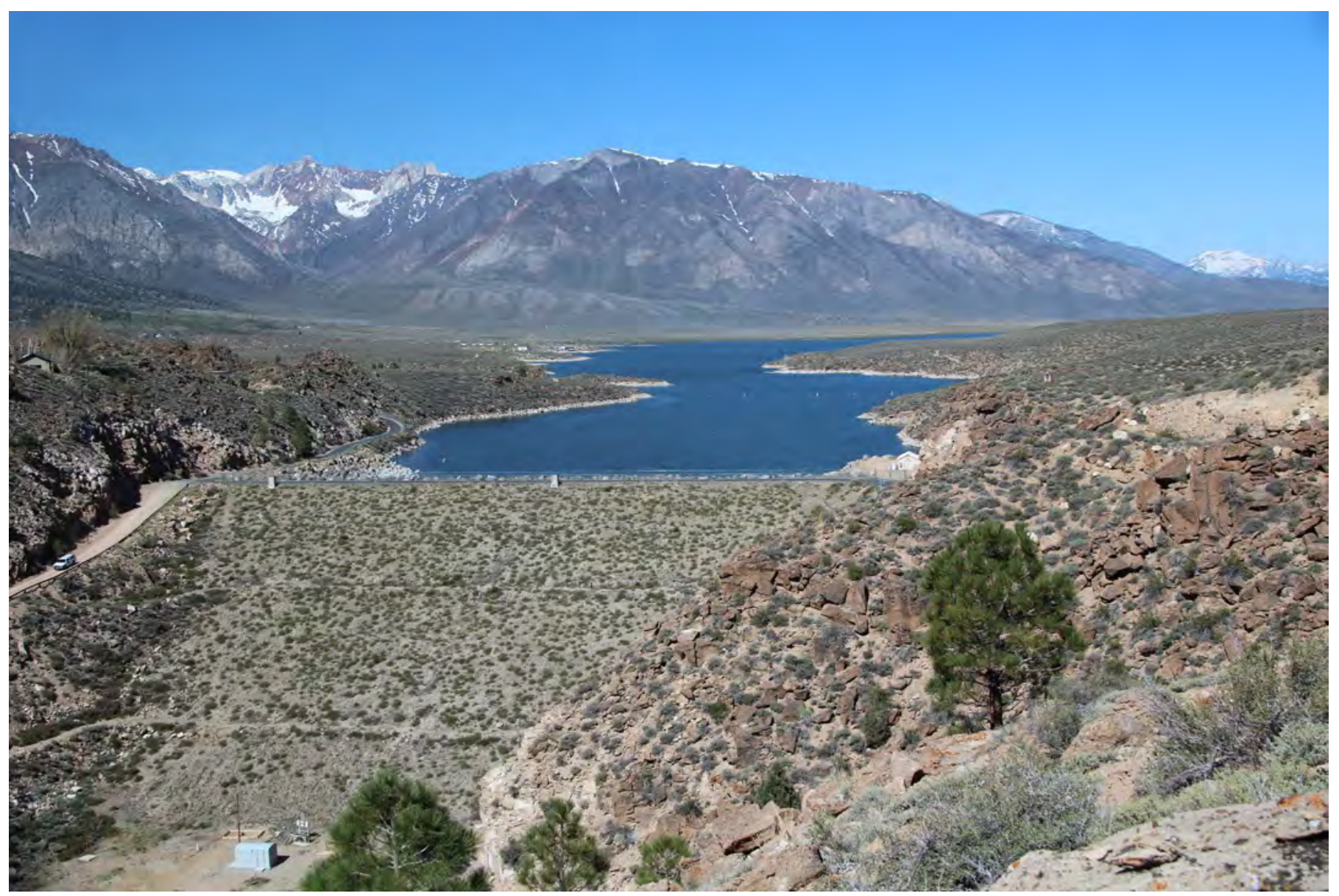

Figure 25. Outlet arm of Lake Crowley reservoir where Long Valley Dam blocks entrance to Owens River Gorge, here $\sim 80 \mathrm{~m}$ deep. Sandstone and pebble conglomerate overlie Bishop Tuff along gorge rim for $\sim 2.4 \mathrm{~km}$ downstream from dam at elevations of 2,090-2,160 $\mathrm{m}$ above sea level, marking highstand of Pleistocene Long Valley Lake where it inundated upper reach of fjord-like inlet prior to overflow and reincision of ignimbrite-filled gorge. Camera is on lakeshore conglomerate at 2,100-m rim; reservoir level is drawn down several meters lower than normal pool level of 2,062 m. At left center, transition from ragged knolls of Bishop Tuff to smooth wave-planed ignimbrite surface (on both sides of lake) marks southward-tilted highstand of Pleistocene lake. View westward across South Landing (buildings) to McGee Mountain (Putnam, 1962) and moraines at mouth of McGee Creek canyon. Snowclad Mammoth Mountain in far right distance. Photo by authors June 2014.

as light as $1.2 \mathrm{~kg} / \mathrm{m}^{3}$ near the Z-bend; density profiles A-D of Wilson and Hildreth, 2003). Such weakly consolidated tuff readily crumbles when weathered, and ubiquitous meter-scale fracturing of the Bishop Tuff renders it susceptible to rapid erosion by block spalling wherever relief is initiated.

Various lines of evidence and inference thus favor eastward advance of the arm of the lake along the former course of the Owens River filled by the Bishop Tuff, impinging ultimately on the basement high where the gorge had been filled with basalt, blocked, and diverted at 3.3 Ma. The barrier formed by the uppermost tens of meters of poorly welded ignimbrite may have been eroded by ephemeral surface runoff gathered by the compactional swale and ultimately by wave action at the head of the advancing inlet. Once the westwardflowing stream that fed the inlet impinged headward onto the pile of basaltic scoria and thin rubbly lavas, reexcavation of the Neogene gorge probably accelerated. Erosion of the more resistant granodiorite was unnecessary because the basalt was the Pliocene fill of a Neogene granodiorite gorge that had earlier been cut as deep as the gorge floor reoccupied today. Little or no granodiorite need have been eroded until the gorge approached its full present-day depth.

On the downstream slope of the granodiorite ridge, it seems unlikely that reincision of the Neogene gorge was concurrently advancing upstream because of the sparse precipitation and runoff and because the densely welded tuff that today walls much of central Owens Gorge (fig. 14) sealed the more erodible rocks below. Once the advancing inlet reached the western flank of the basaltic blockage, the basalt surface was at least $20 \mathrm{~m}$ lower in elevation than the well-established level of Long Valley Lake's highstand at its outlet. By then, the inlet had become the outlet, overflow had been initiated, lake level was necessarily declining, and progressive deepening of the present-day gorge was underway. No headward advance of the lower gorge upstream from Owens Valley was needed. 
If lake depth at the time of overflow had been as great as $50 \mathrm{~m}$ (the difference between the 2,150-m highstand at the outlet arm and the many quasi-accordant $\sim 2,100$-m siltstone mesas that represent the youngest lake-floor deposits preserved), and if the lake's highstand area had been $\sim 320 \mathrm{~km}^{2}$, then its water volume could have been as great as $16 \mathrm{~km}^{3}$ certainly a maximum estimate owing to northward and lateral shallowing of the lake and an unknown amount of erosion atop the siltstone mesas. If post-lake axial erosion has stripped tens of meters of silt or if the late-stage lake had been only $\sim 15 \mathrm{~m}$ deep (as suggested by diatoms and ostracods), then water volume may have been as little as $\sim 5 \mathrm{~km}^{3}$. Draining of a lake so modest is unlikely to have induced significant isostatic rebound, and, in any case, no geometrically appropriate bulge of lake silts or shorelines has been detected. Caldera resurgence and regional tectonic warping could have obscured minor isostatic effects. Greater isostatic adjustments had probably attended dispersal of mass by the caldera-forming eruption and secular deposition of $700 \mathrm{~m}$ of fill. For comparison, removal of the load of late Pleistocene Lake Bonneville $\left(52,000 \mathrm{~km}^{2} ; 9,500 \mathrm{~km}^{3}\right.$; maximum depth $\left.\sim 380 \mathrm{~m}\right)$ caused vertical rebound as great as $60-70 \mathrm{~m}$ in the center of the basin, but contemporaneous smaller lakes in Utah and Nevada (20-74 m deep, $120-1,400 \mathrm{~km}^{2}$ in area, and 2-40 $\mathrm{km}^{3}$ in volume) showed no independently detectable isostatic deflection of their shorelines (Bills and others, 1994). Likewise, none is recognized at Long Valley.

Neither have we found evidence for catastrophic breakout and downcutting. No flood breccia, beachrock blocks, or debris-flow deposits are recognized downstream. Moderately welded block-jointed Bishop Tuff might erode steadily after initiation of overflow but is unlikely to have been excavated cataclysmically.

We earlier mentioned (in the section "Shoreline Evidence") sets of 3-5 faintly observable lower shorelines preserved in six patches around the margins of Pleistocene Long Valley Lake (fig. 8; appendix 2). It will take extensive lidar (light detection and ranging) imagery to locate and study them with useful precision. All sets are at elevations (2,140-2,200 m) well below adjacent highstand shorelines, but in every case the reference highstand has been deformed. The sets are today largely higher than the tilted highstand shoreline at the outlet $(\sim 2,150 \mathrm{~m})$, but they are well below the pre-tilt highstand, which (as discussed earlier) is inferred to have been around 2,265 $\mathrm{m}$ asl. Five of the sets are in areas along the flank of the resurgent uplift, and one is along the southwardtilted slope near Watterson Canyon. The last set mentioned is cut into a wave-planed slope of Glass Mountain pyroclastic deposits, well below the highstand scarp of Bishop Tuff (fig. 10 ), and the other five sets are wave-etched into littoral slopes of pebbly sandstone that had been deposited and indurated much earlier. Although wave action slightly displaced or tilted slabs of the previously indurated sandstone, we recognize no evidence that any of the six sets underwent extensive subaqueous erosion, or burial by younger lake sediment, or tufa deposition. These features and the weak strandline development (relative to the pronounced highstand shoreline) persuade us that all six sets represent transient lake levels during stepwise lowering of the lake after overflow had commenced. With no evidence for catastrophic breach, gradual entrenchment of the outlet permitted weak etching of successively lower strandlines. During the regression, there was little loose debris atop the indurated sandstone apron for wave action to work into new littoral deposits. It seems compelling that regression was short-lived relative to the 600,000 years of transgressive filling of the basin.

Paul Bateman (1965, his fig. 80) mapped a shallow abandoned stream channel that trends east-southeast across the southwest part of the Volcanic Tableland (fig. 3). We found well-rounded granodioritic and metasedimentary pebbles and cobbles at two sites along its now-discontinuous multi-faulted course. One site has only scattered pebbles but the larger remnant ( $\sim 1 \mathrm{~m}$ thick) is dominated by grussy cobbles of Wheeler Crest Granodiorite in a grussy matrix of coarse sand and granules. The lithology suggests an Owens River provenance (rather than granitic Casa Diablo Mountain), the weathered cobbles suggest antiquity, and the lack of basaltic clasts suggests deposition during a very early stage of overflow, prior to deep incision of the gorge.

Remnant segments of abandoned meanders stranded 15-40 m below the left-bank rim of central Owens Gorge (where it is today 120-220 m deep) are further evidence of a modest-relief streambed that wound across the Volcanic Tableland prior to deep entrenchment. In traditional terminology, the stream that first overflowed was consequent upon the gently sloping ignimbrite surface, but as southward tectonic tilting steepened the gradient, increasing stream power promoted deepening of some of the early meanders, which are thus antecedent to post-overflow tilting of the Volcanic Tableland. A few similarly shallow stranded meander segments are preserved along the ignimbrite rim of distal Rock Creek gorge.

At the mouth of Owens River Gorge, a set of fluvial terraces higher than the active modern floodplain is preserved on the interfluve (UTM 680/400) between Horton Creek and the Owens River (fig. 3). In addition to stream cobbles of varied granitic and metasedimentary rocks and Bishop Tuff, the terraces contain cobbles of olivine basalt, the only upstream source of which is the Pliocene shield that blocked the river. Compositionally, the cobbles are indistinguishable from the shield lavas (appendix 1). If Pinter and others (1994) are correct that the top (oldest) terrace (elevation 1,350-1,370 $\mathrm{m}$ asl) on the interfluve correlates with the Tahoe glaciation, this would agree with our inference that Long Valley Lake overflowed and began to reincise through the basaltic blockage during MIS 6. Terrace remnants south of Horton Creek, also at 1,350-1,370 m, lack the basaltic cobbles; they need not be older than MIS 6, however, as they consist of gravels transported by ancestral Horton Creek, not by Owens River.

Figure $26 A-E$ is an overall summary of the sequence of stages in development of the Owens River across what are today Long Valley and the Volcanic Tableland. The extended five-part caption provides a condensed recapitulation of our inferences and conclusions. 


\section{A. Mid-Pliocene}

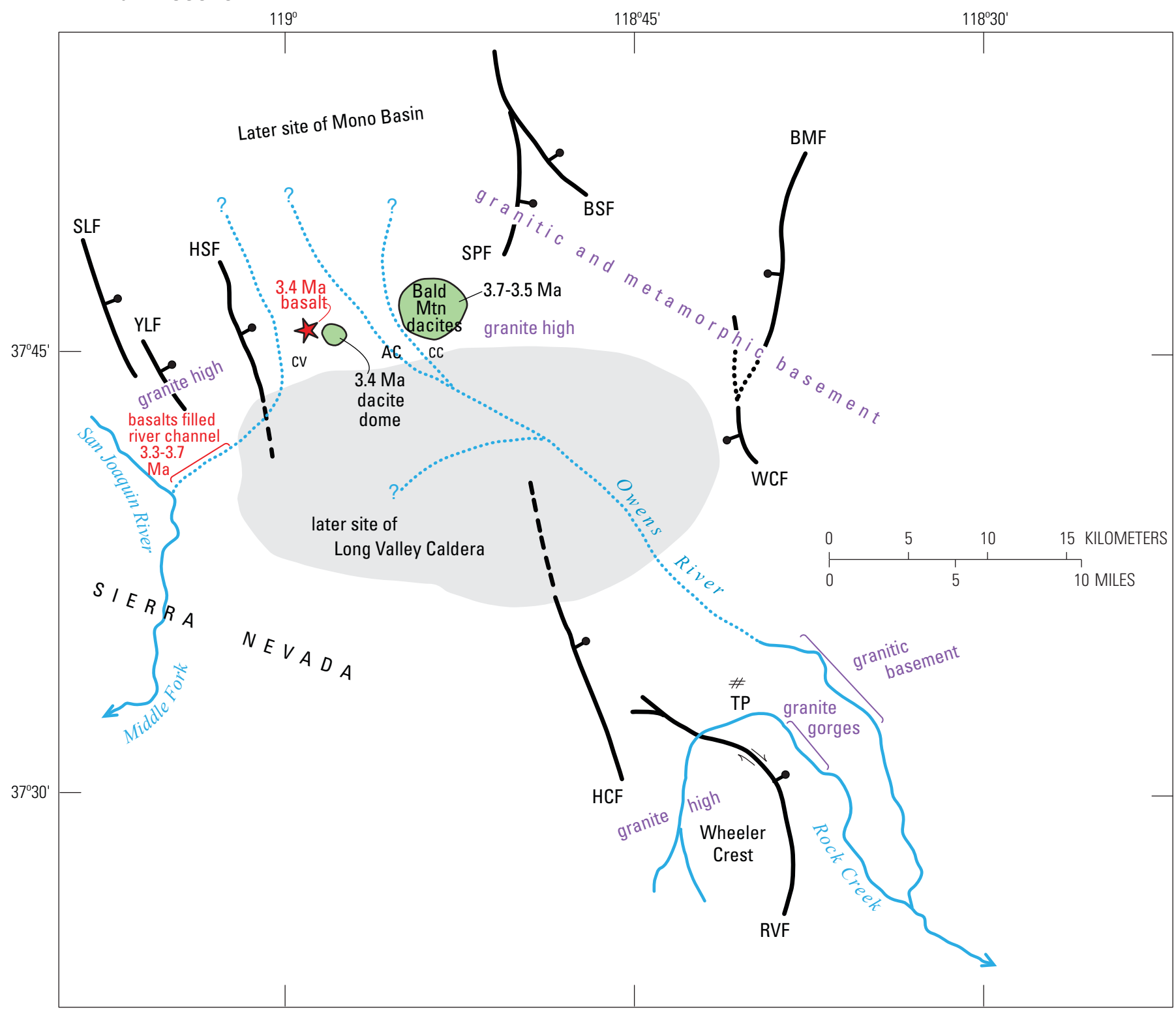

Figure 26A. Summary of drainage history. A, Mid-Pliocene. Precaldera Owens River drained parts of Sierra Nevada and highland region that later subsided as Mono Basin. To northwest, Pliocene basalts and dacites helped frame channel of Owens River between granite highs via Clark (CC) and Alpers Canyons (AC) (figs. 1, 5). Another such channel, tributary to the San Joaquin River via the basement low near modern Crestview (CV), was filled and permanently blocked by a thick stack of basalts that erupted from 3.7 to 3.3 Ma. Course of Owens River across later site of caldera was influenced by major left step (from Hilton Creek Fault to Hartley Springs Fault) in the then-incipient rangefront fault system. Faults shown developed great relief in the Quaternary, but all shown here were probably initiated by the late Pliocene. To southeast, gorges $200 \mathrm{~m}$ deep were cut through a basement ridge by both Rock Creek and Owens River. Abbreviations: AC, Alpers Canyon; BMF, Black Mountain Fault; BSF, Baxter Spring Fault; CC, Clark Canyon; CV, site of modern Crestview; HCF, Hilton Creek Fault; HSF, Hartley Springs Fault; RVF, Round Valley Fault; SLF, Silver Lake Fault; SPF, Sagehen Peak Fault; TP, site of modern Toms Place; WCF, Wilfred Canyon Fault; YLF, Yost Lake Fault. 


\section{B. Post-basalt; pre-Sherwin}

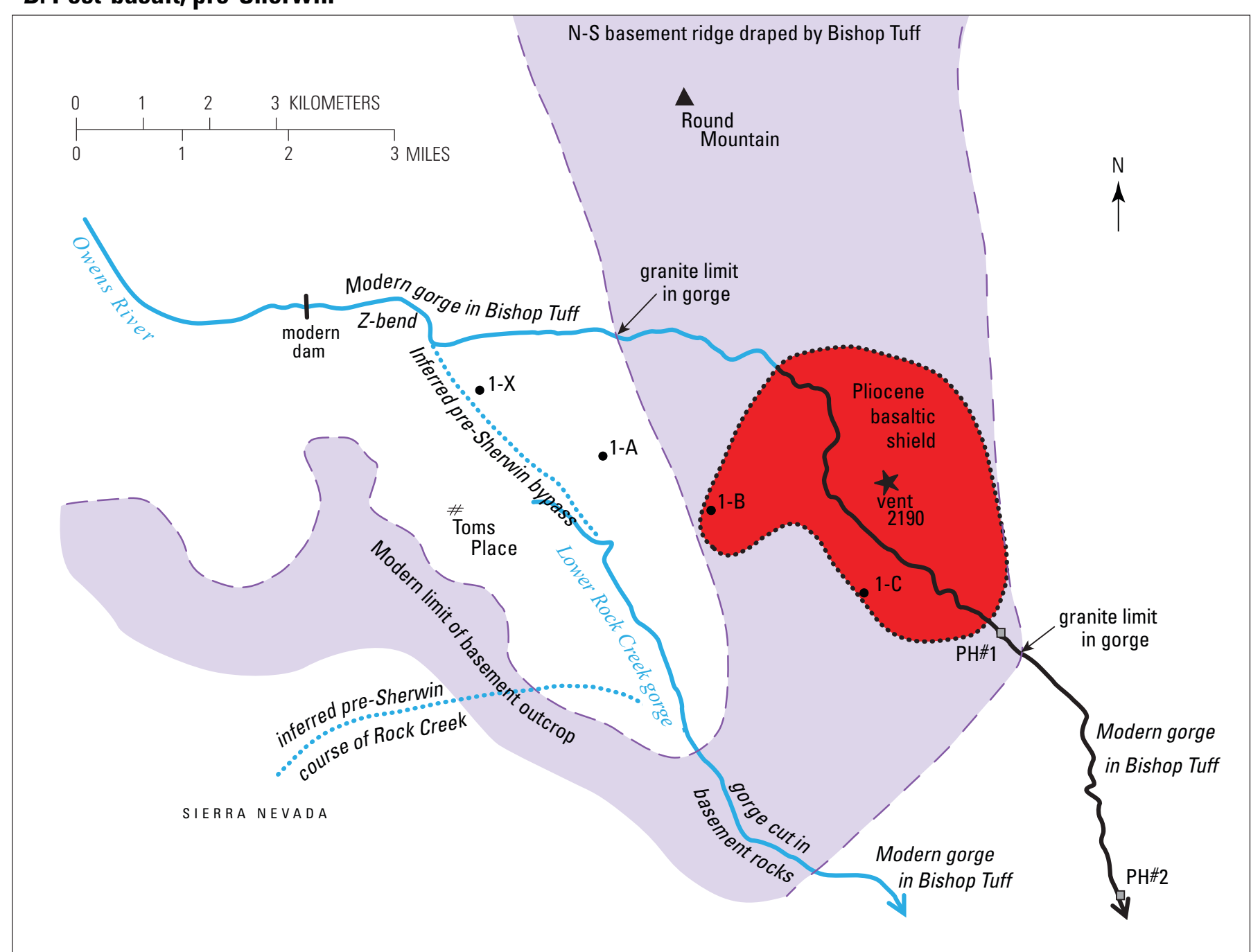

Figure 26B. 3.3 Ma until Sherwin Glaciation 900-866 ka. Basaltic shield filled and blocked Owens River Gorge at $3.3 \mathrm{Ma}$, forcing river to establish new channel to Rock Creek. Blue lines are perennial creeks; black line is basalt-buried and beheaded reaches of Owens River. Sites of four test holes for Los Angeles Department of Water and Power tunnel \#1, labelled as in figures 6 and 11, provide subsurface control. Sites of power houses (PH) \#1 and \#2 and modern Long Valley Dam are located as reference points. 


\section{C. $\sim 900-866 \mathrm{ka}$}

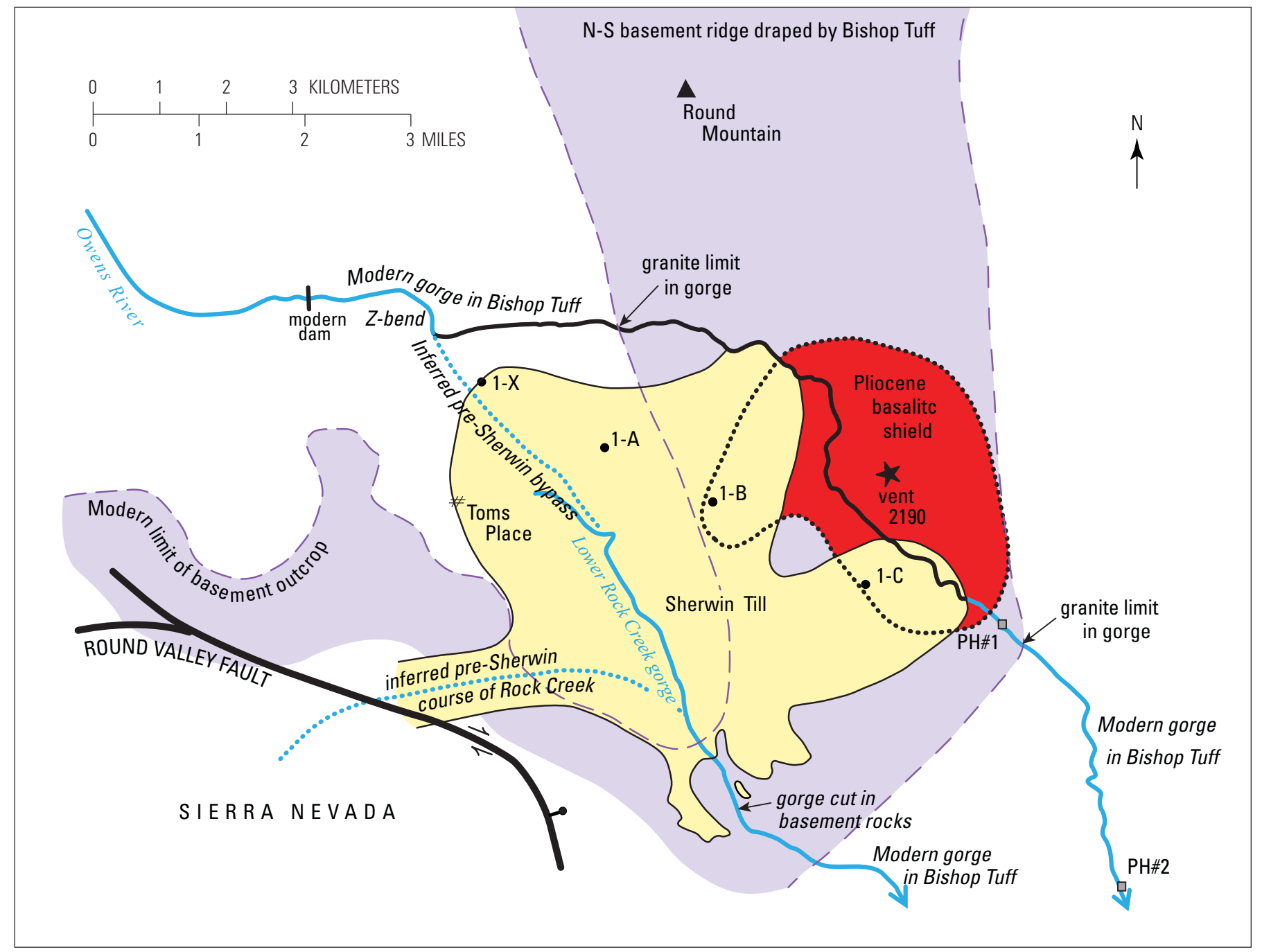

Figure 26C. Sherwin glaciation $~ 900-866 \mathrm{ka}$. Sherwin Till, as thick as $200 \mathrm{~m}$, was deposited by a piedmont glacier that spread out from the narrow Sierran canyon of Rock Creek. Till overlaps the basaltic shield, elsewhere rests on basement rocks, and invaded Rock Creek gorge. Eastern lobe crossed the basalt-filled segment of Owens Gorge (figs. 15A, 16). Putnam (1960) mapped northern lobe of till as also crossing Owens Gorge, but neither we nor Rinehart and Ross (1957) found it on the north wall there. Meltwater from Sherwin glacier drained down both Rock Creek and lower Owens Gorge. Other features labelled as in panel B. 


\section{767 ka}

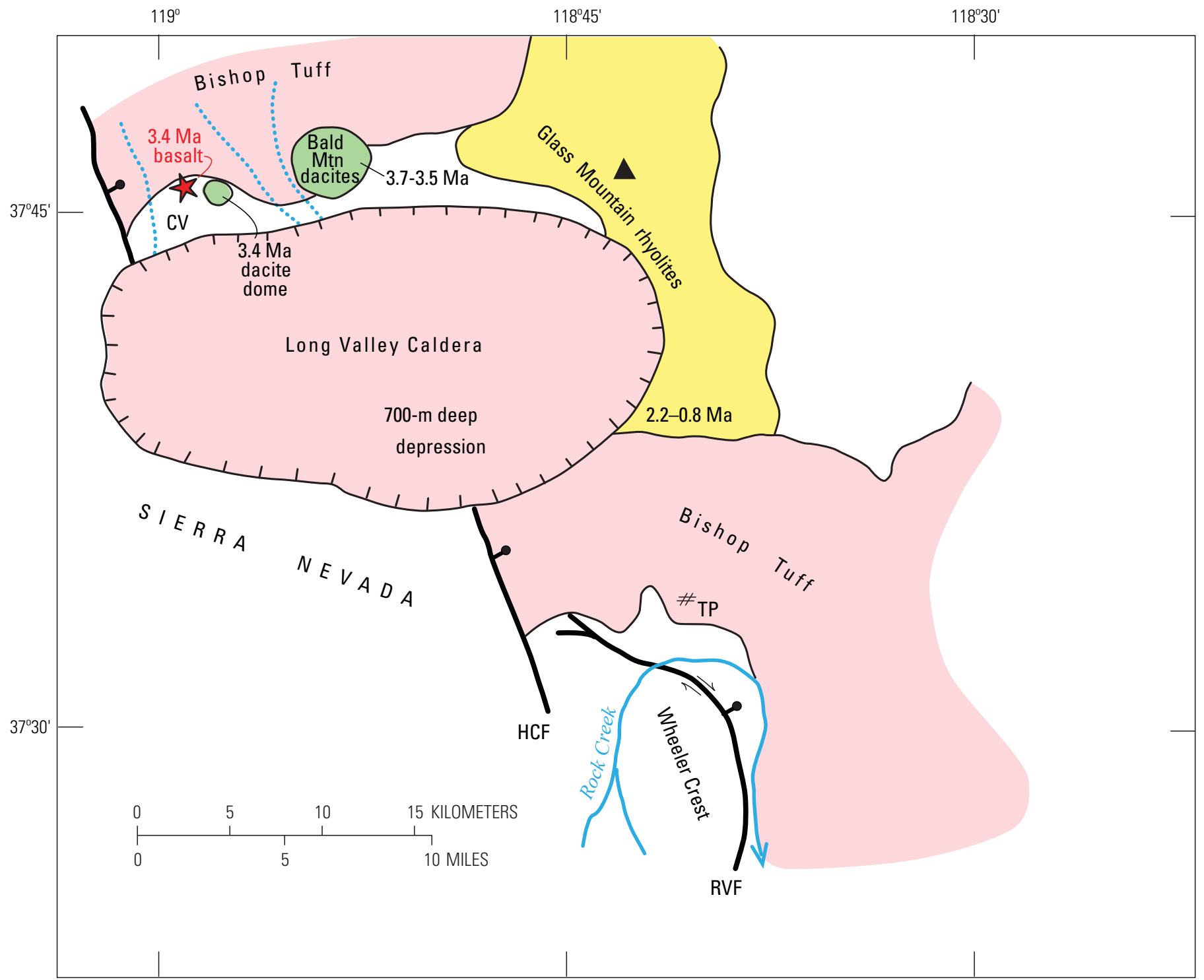

Figure 26D. Caldera-forming eruption $\sim 767 \mathrm{ka}$. Ignimbrite filled, covered, and obliterated Owens River drainage. Collapsed depression trapped 1-1.5 km $\mathrm{km}^{3}$ of Bishop Tuff, but an intracaldera well shows top surface of the ignimbrite to lie $700 \mathrm{~m}$ lower than southeast rim (the much later spillpoint of the caldera lake). The profound basin soon began collecting a caldera lake, which required $\sim 600,000$ years to fill to its threshold for overflow. Rock Creek continued to drain the Sierra Nevada and, like Owens River Gorge, its former course was eventually reexcavated through the Bishop Tuff, probably facilitated by a compactional swale centered above its ignimbrite-filled paleogorge. For paleodrainages truncated by northwest rim of caldera, see panel $A$. Abbreviations as in panel $A$. 


\section{E. 180 ka}

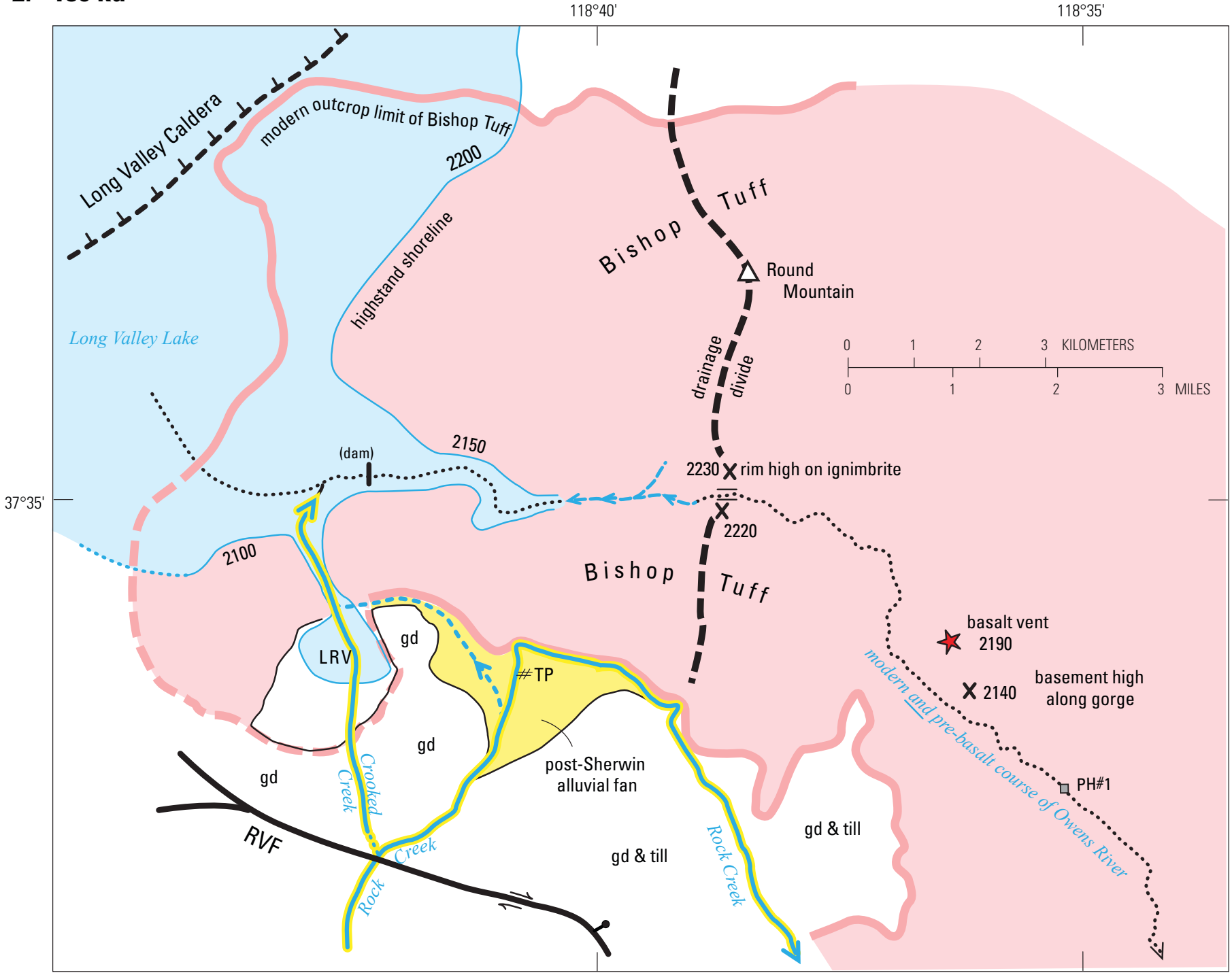

Figure 26E. Highstand of Long Valley Lake $\sim 180 \mathrm{ka}$. When the caldera depression had filled with $700 \mathrm{~m}$ of sediment, the lake approached its threshold and began advancing eastward along a fjord-like inlet. The compactional swale above the ignimbrite-filled precaldera river channel gathered seasonal or intermittent runoff, which drained westward toward the lake and eroded headward (eastward) toward the drainage divide. Only when the inlet breached the divide did the lake begin to overflow, and then the inlet became the outlet. Because high points on the basaltic shield and granodioritic basement (gd) were lower than the ignimbrite divide (figs. 11, 13), the overflow initiated excavation of the rubbly basaltic blockage from the 200-m-deep pre-basalt gorge cut in the granodiorite, thereby reestablishing the course of the Pliocene Owens River toward Owens Valley. In the middle Pleistocene, Crooked Creek had flowed into Long Valley Lake, helping to strip 200 m of Bishop Tuff from Little Round Valley (LRV; fig. 19). Dextral and normal offset on Round Valley Fault (RVF) promoted redirection of Rock Creek northeast toward Toms Place (see panels B, C), building a coarse alluvial fan that prevented overflow toward Rock Creek when the lake, at its highstand, spilled shallowly into Little Round Valley. 


\section{References Cited}

Adams, K.D., and Wesnousky, S.G., 1998, Shoreline processes and the age of the Lake Lahontan highstand in the Jessup embayment, Nevada: Geological Society of America Bulletin, v. 110, p. 1318-1332.

Bachman, S.B., 1978, Pliocene-Pleistocene break-up of the Sierra Nevada - White-Inyo Mountains block and formation of Owens Valley: Geology, v. 6. p. 461-463.

Bacon, C.R., Gardner, J.V., Mayer, L.A., Buktenica, M.W., Dartnell, P., Ramsey, D.W., and Robinson, J.E., 2002, Morphology, volcanism, and mass wasting in Crater Lake, Oregon: Geological Society of America Bulletin, v. 114, p. 675-692.

Bailey, R.A., 1989, Geologic map of Long Valley caldera, Mono-Inyo Craters volcanic chain, and vicinity, eastern California: U.S. Geological Survey Map I-1933, scale 1:62,500, 2 sheets; pamphlet 11 p.

Bailey, R.A., Dalrymple, G.B., and Lanphere, M.A., 1976, Volcanism, structure, and geochronology of Long Valley caldera, Mono County, California: Journal of Geophysical Research, v. 81, no. 5, p. 725-744.

Bateman, P.C., 1965, Geology and tungsten mineralization of the Bishop District, California: U.S. Geological Survey Professional Paper 470, 208 p.

Bateman, P.C., 1992, Plutonism in the central part of the Sierra Nevada batholith, California: U.S. Geological Survey Professional Paper 1483, 186 p.

Berger, W.H., Bickert, T., Schmidt, H., and Wefer, G., 1993, Quaternary oxygen isotope record of pelagic foraminifersSite 806, Ontong Java Plateau, in Berger, W.H., Kroenke, L.W., Mayer, L.A., eds., Proceedings of the Ocean Drilling Program, Scientific results: v. 130, p. 381-395, College Station, Texas, Ocean Drilling Program.

Bills, B.G., Currey, D.R., and Marshall, G.A., 1994, Viscosity estimates for the crust and upper mantle from patterns of lacustrine shoreline deformation in the Eastern Great Basin: Journal of Geophysical Research, v. 99, no. B11, p. 22,059-22,086.

Blackwelder, E., 1931, Pleistocene glaciation in the Sierra Nevada and Basin Ranges: Geological Society of America Bulletin, v. 42, p. 865-922.

Bradbury, J.P., 1997, A diatom-based paleohydrologic record of climate change for the past $800 \mathrm{k}$.y. from Owens Lake, California, in Smith, G.I., and Bischoff, J.L., eds., An 800,000-year Paleoclimatic Record from Core OL-92, Owens Lake, Southeast California: Geological Society of America Special Paper 317, p. 99-112.
Carle, S.F., 1988, Three-dimensional gravity modeling of the geologic structure of Long Valley caldera: Journal of Geophysical Research, v. 93, no. B11, p. 13,237-13,250.

Channell, J.E.T., 2006, Late Brunhes polarity excursions (Mono Lake, Laschamp, Iceland Basin and Pringle Falls) recorded at ODP Site 919 (Irminger Basin): Earth and Planetary Science Letters, v. 244, p. 378-393.

Cheng, H., Edwards, R.L., Shen, C.-C., Polyak, V.J., Asmerom, Y., Woodhead, J., Hellstrom, J., Wang, Y., Kong, X., Spötl, C., Wang, X., and Alexander, E.C., Jr., 2013, Improvements in ${ }^{230} \mathrm{Th}$ dating, ${ }^{230} \mathrm{Th}$ and ${ }^{234} \mathrm{U}$ half-life values, and U-Th isotopic measurements by multi-collector inductively coupled plasma mass spectrometry: Earth and Planetary Science Letters, v. 371-372, p. 82-91.

City of Los Angeles, 1937, Topographic map of Long Valley Reservoir (unpublished): Bureau of Water Works and Supply, Drawing Number Indep. 9076, scale 1 inch=1,000 feet.

Dalrymple, G.B., 1963, Potassium-argon dates of some Cenozoic volcanic rocks of the Sierra Nevada, California: Geological Society of America Bulletin, v. 74, p. 379-390.

Dawers, N.H., Anders, M.H., and Scholtz, C.H., 1993, Growth of normal faults - Displacement-length scaling: Geology, v. 21, p. 1107-1110.

Eichelberger, J.C., Vogel, T.A., Younker, L.W., Miller, C.D., Heiken, G.H., and Wohletz, K.H., 1988, Structure and stratigraphy beneath a young phreatic vent - South Inyo Crater, Long Valley Caldera, California: Journal of Geophysical Research, v. 93, p. 13,208-13,220.

Ferrill, D.A., Stamatakos, J.A., and Sims, D., 1999, Normal fault corrugation-Implications for growth and seismicity of active normal faults: Journal of Structural Geology, v. 21, p. 1027-1038.

Fournier, R.B., 1989, Lithology, mineralogy, and paleontology of Quaternary lake deposits in Long Valley caldera, California: U.S. Geological Survey Open-File Report 89-413, 95 p.

Gilbert, C.M., 1938, Welded tuff in eastern California: Geological Society of America Bulletin, v. 49, p. 1829-1862.

Greene, D.C., and Stevens, C.H., 2002, Geologic map of Paleozoic rocks in the Mount Morrison Pendant, eastern Sierra Nevada, California: California Division of Mines and Geology Map Sheet 53, scale 1:24,000.

Gresswell, W.K., 1940, Short report on geological formations encountered in driving the Mono Craters tunnel: California Division of Mines and Geology Bulletin, v. 36, p. 199-204. 
Herrero-Bervera, E., and Cañón-Tapia, E., 2012, On the directional geomagnetic signature of the Pringle Falls excursion recorded at Pringle Falls, Oregon, USA, in Jovane, L., Herrero-Bervera, E., Hinnov, E., and Housen, B.A., eds., Magnetic methods and the timing of geological processes: Geological Society of London Special Publication 373, 16 p.

Herrero-Bervera, E., Helsley, C.E., Sarna-Wojcicki, A.M., Lajoie, K.R., Meyer, C.E., McWilliams, M.O., Negrini, R.M., Turrin, B.D., Donnelly-Nolan, J.M., and Liddicoat, J.C., 1994, Age and correlation of a paleomagnetic episode in the western United States by ${ }^{40} \mathrm{Ar} /{ }^{39} \mathrm{Ar}$ dating and tephrochronology - The Jamaica, Blake, or a new polarity episode? Journal of Geophysical Research, v. 99, p. 24,091$24,103$.

Heumann, A., 1999, Timescales of processes within silicic magma chambers: Amsterdam, Vrije Universiteit, Ph.D. thesis, $200 \mathrm{p}$.

Heumann, A., Davies, G.R., and Elliott, T., 2002, Crystallization history of rhyolites at Long Valley, California, inferred from combined $\mathrm{U}$-series and $\mathrm{Rb}-\mathrm{Sr}$ isotope systematics: Geochimica et Cosmochimica Acta, v. 66, no. 10, p. 18211837.

Hildreth, W., 2004, Volcanological perspectives on Long Valley, Mammoth Mountain, and Mono Craters: several contiguous but discrete systems: Journal of Volcanology and Geothermal Research, v. 136, p. 169-198.

Hildreth, W., and Fierstein, J., 2012, The Novarupta-Katmai eruption of 1912 - largest eruption of the twentieth century-Centennial perspectives: U.S. Geological Survey Professional Paper 1791, $260 \mathrm{p}$.

Hildreth, W., and Fierstein, J., 2016, 128 p. Eruptive history of Mammoth Mountain and its mafic periphery: U.S. Geological Survey Professional Paper 1812, 128 p., 2 sheets, scale $1: 24,000$.

Hildreth, W., Fierstein, J., Champion, D, and Calvert, A., 2014, Mammoth Mountain and its mafic periphery-A late Quaternary volcanic field in eastern California: Geosphere, v. 10, no. 6 , p. $1315-1365$.

Hildreth, W., and Mahood, G.A., 1986, Ring-fracture eruption of the Bishop Tuff: Geological Society of America Bulletin, v. 97 , p. 396-403.

Hill, D.P., 1976, Structure of Long Valley caldera, California, from a seismic refraction experiment: Journal of Geophysical Research, v. 81, p. 745-753.

Huber, N.K., 1981, Amount and timing of late Cenozoic uplift and tilt of the central Sierra Nevada-Evidence from the upper San Joaquin River basin: U.S. Geological Survey Professional Paper 1197, $28 \mathrm{p}$.
Jacques, H.L., 1940, Mono Craters tunnel construction problems: Journal of the American Water Works Association, v. 32 , no. 1, p. $43-56$.

Jaffey, A.H., Flynn, K.F., Glendennin, L.E., Bentley, W.C., and Essling, A.M., 1971, Precision measurement of half-lives and specific activities of ${ }^{235} \mathrm{U}$ and ${ }^{238} \mathrm{U}$ : Physical Review $\mathrm{C}$, v. 4, p. 1889-1906.

Kurth, G., Phillips, F.M., Reheis, M.C., Redwine, J.L., and Paces, J.B., 2011, Cosmogenic nuclide and uranium-series dating of old, high shorelines in the western Great Basin, USA: Geological Society of America Bulletin, v. 123, p. 744-768.

Langbein, J.O., 2003, Deformation of the Long Valley caldera, California-Inferences from measurements from 1988 to 2001: Journal of Volcanology and Geothermal Research, v. 127, p. $247-267$.

Lewis, R.E., 1975, Data from a 1,000-foot (305-metre) core hole in the Long Valley caldera, Mono County, California: U.S. Geological Survey Open-File Report 75-683, 16 p.

Liddicoat, J.C., 1990, Aborted reversal of the palaeomagnetic field in the Brunhes Normal Chron in east-central California: Geophysical Journal International, v. 102, p. 747-752.

Liddicoat, J.C., and Bailey, R.A., 1989, Short reversal of the palaeomagnetic field about 280,000 years ago at Long Valley, California, in Lowes, F.J., Collinson, D.W., Parry, J.H., Runcorn, S.K., Tozer, D.C., and Soward, A., eds., Geomagnetism and palaeomagnetism: Dordrecht, The Netherlands, Kluwer Academic Publishers (NATO Science Series C, v. 261), p. 137-153.

Liddicoat, J.C., Opdyke, N.D., and Smith, G.I., 1980, Paleomagnetic polarity in a 930-m core from Searles Valley, California: Nature, v. 286, p. 22-25.

Liddicoat, J.C., Coe, R.S., and Glen, J.M., 1998, Record of the younger part of the Pringle Falls excursion at Long Valley, California: Geophysical Journal International, v. 135, p. 663-670.

Lisiecki, L.E., and Raymo, M.E., 2005, A Pliocene-Pleistocene stack of 57 globally distributed $\delta^{18} \mathrm{O}$ records: Paleoceanography, v. 20, PA 1003, doi:10.1029/2004PA001071.

Lueddecke, S.B., Pinter, N., and Gans, P., 1998, Plio-Pleistocene ash falls, sedimentation, and range-front faulting along the White-Inyo Mountains front: Journal of Geology, v. 106, p. 511-522.

Mankinen, E.A., Grommé, C.S., Dalrymple, G.B., Lanphere, M.A., and Bailey, R.A., 1986, Paleomagnetism and K-Ar ages of volcanic rocks from Long Valley caldera, California: Journal of Geophysical Research, v. 91, p. 633-652. 
Marcaida, M., Mangan, M.T., Vazquez, J.A., Bursik, M., and Lidzbarski, M.I., 2014, Geochemical fingerprinting of Wilson Creek formation tephra layers (Mono Basin, California) using titanomagnetite compositions: Journal of Volcanology and Geothermal Research, v. 273, p. 1-14.

Mason, W.C., 1949, Los Angeles builds three hydro plants in Owens River Gorge: Civil Engineering, v. 19, p. 820-823, 891.

Matsubara, Y., and A. D. Howard, 2009, A spatially explicit model of runoff, evaporation, and lake extent: Application to modern and late Pleistocene lakes in the Great Basin region, western United States: Water Resources Research, v. 45, W06425, doi:10.1029/2007WR005953.

Mayo, E.B., 1934, The Pleistocene Long Valley Lake in eastern California: Science, v. 80, p. 95-96.

Mifflin, M.D., and Wheat, M.M., 1979, Pluvial lakes and estimated pluvial climates of Nevada: Nevada Bureau of Mines and Geology Bulletin 94, 57 p.

Morris, S.B., 1955, Owens Gorge Project: American Society of Civil Engineers, Proceedings, v. 81, no. 738, 25 p.

Muttoni, G., Carcano, C., Garzanti, E., Ghielmi, M., Piccin, A., Pini, R., Rogledi, S., and Sciunnach, D., 2003, Onset of major Pleistocene glaciations in the Alps: Geology, v. 31, no.11, p. 989-992.

Nathenson, M., Bacon, C.R., and Ramsey, D.W., 2007, Subaqueous geology and a filling model for Crater Lake, Oregon: Hydrobiologia, v. 574, p. 13-27.

Phillips, F.M., 2008, Geological and hydrological history of the paleo-Owens River drainage since the late Miocene, in Reheis, M.C., Hershler, R., and Miller, D.M., eds., Late Cenozoic Drainage History of the Southwestern Great Basin and Lower Colorado River Region: Geologic and Biotic Perspectives: Geological Society of America Special Paper 439 , p. $115-150$.

Phillips, F.M., and Majkowski, L., 2011, The role of low-angle normal faulting in active tectonics of the northern Owens Valley, California: Lithosphere, v. 3, no. 1, p. 22-36.

Pinter, N., 1995, Faulting on the Volcanic Tableland, Owens Valley, California: Journal of Geology, v. 103, p. 73-83.

Pinter, N., Keller, E.A., and West, R.B., 1994, Relative dating of terraces of the Owens River, northern Owens Valley, California, and correlation with moraines of the Sierra Nevada: Quaternary Research, v. 42, p. 266-276.

Placzek, C., Patchett, P.J., Quade, J., and Wagner, J.D.M., 2006, Strategies for successful U-Th dating of paleolake carbonates: An example from the Bolivian Altiplano: Geochemistry Geophysics Geosystems, v. 7, no. 5, Q05024, doi:10.1029/2005GC001157.
Putnam, W.C., 1952, Origin of Rock Creek and Owens River gorges, California: Geological Society of America Bulletin, v. 63, p. 1291-1292.

Putnam, W.C., 1960, Origin of Rock Creek and Owens River gorges, Mono County, California: University of California Publications in Geological Sciences, v. 34, p. 221-280.

Putnam, W.C., 1962, Late Cenozoic geology of McGee Mountain, Mono County, California: University of California Publications in Geological Sciences, v. 40, no. 3, p. 181-207.

Reheis, M., 1999, Highest pluvial-lake shorelines and Pleistocene climate of the western Great Basin: Quaternary Research, v. 52, p. 196-205.

Reheis, M.C., Adams, K.D., Oviatt, C.G., and Bacon, S.N., 2014, Pluvial lakes in the Great Basin of the western United States - A view from the outcrop: Quaternary Science Reviews, v. 97, p. 33-57.

Reheis, M.C., Sarna-Wojcicki, A.M., Reynolds, R.L., Repenning, C.A., and Mifflin, M.D., 2002, Pliocene to middle Pleistocene lakes in the western Great Basin: Ages and connections, in Hershler, R., Madsen, D.B., and Currey, D.R., eds., Great Basin Aquatic Systems History: Smithsonian Contributions to the Earth Sciences, no. 33, p. 53-108.

Rinehart, C.D., and Ross, D.C., 1957, Geology of the Casa Diablo Mountain quadrangle, California: U.S. Geological Survey Map GQ-99, scale 1:62,500.

Rinehart, C.D., and Ross, D.C., 1964, Geology and mineral deposits of the Mount Morrison Quadrangle, Sierra Nevada, California: U.S. Geological Survey Professional Paper 385, $106 \mathrm{p}$.

Sarna-Wojcicki, A.M., Meyer, C.E., and Wan, E., 1997, Age and correlation of tephra layers, position of the MatuyamaBrunhes chron boundaryand effects of Bishop ash eruption on Owens Lake, as determined from drill hole OL-92, southeast California, in Smith, G.I., and Bischoff, J.L., eds., An 800,000-year Paleoclimatic Record from Core OL-92, Owens Lake, Southeast California: Boulder, Colorado, Geological Society of America Special Paper 317, p. 79-90.

Scholl, D.W., von Huene, R., St-Amand, P., and Ridlon, J.B., 1967, Age and origin of topography beneath Mono Lake, a remnant Pleistocene lake, California: Geological Society of America Bulletin, v. 78, p. 583-600.

Sharp, R.P., 1968, Sherwin Till-Bishop Tuff geological relationships, Sierra Nevada, California: Geological Society of America Bulletin, v. 79, p. 351-364.

Sheridan, M.F., 1970, Fumarolic mounds and ridges of the Bishop Tuff, California: Geological Society of America Bulletin, v. 81, p. 851-868. 
Simon, J.I., Weis, D., DePaolo, D.J., Renne, P.R., Mundil, R., and Schmitt, A.K., 2014, Assimilation of preexisting Pleistocene intrusions at Long Valley by periodic magma recharge accelerates rhyolite generation: rethinking the remelting model: Contributions to Mineralogy and Petrology, v. 167:955, 35 p.

Singer, B.S., Jicha, B.R., Kirby, B.T., Geissman, J.W., and Herrero-Bervera, E., 2008, ${ }^{40} \mathrm{Ar} /{ }^{39} \mathrm{Ar}$ dating links Albuquerque Volcanoes to the Pringle Falls excursion and the Geomagnetic Instability Time Scale: Earth and Planetary Science Letters, v. 267, p. 584-595.

Smith, G.I., 1976, Origin of lithium and other components in the Searles Lake evaporites, California, in Vine, J.D., ed., Lithium resources and requirements by the year 2000: U.S. Geological Survey Professional Paper 1005, p. 92-103.

Smith, G.I., 2009, Late Cenozoic geology and lacustrine history of Searles Valley, Inyo and San Bernardino Counties, California: U.S. Geological Survey Professional Paper $1727,115 \mathrm{p}$.

Smith, G.I., Barczak, V.J., Moulton, G.F., and Liddicoat, J.C., 1983, Core KM-3, a surface-to-bedrock record of late Cenozoic sedimentation in Searles Valley, California: U.S. Geological Survey Professional Paper 1256, 24 p.

Smith, G.I., and Bischoff, J.L., eds., 1997, An 800,000-year paleoclimatic record from core OL-92, Owens Lake, southeast California: Geological Society of America Special Paper 317, 165 p.

Smith, G.I., Bischoff, J.L., and Bradbury, J.P., 1997, Synthesis of the paleoclimatic record from Owens Lake core OL-92, in Smith, G.I., and Bischoff, J.L., eds., An 800,000year paleoclimatic record from core OL-92, Owens Lake, southeast California: Geological Society of America Special Paper 317, p. 143-160.

Smith, J.L., and Rex, R.W., 1977, Drilling results from the eastern Long Valley caldera: American Nuclear Society Meeting on Energy and Mineral Recovery Research, Golden, Colorado, April 12-14, 1977, p. 529-540.

Sorey, M.L., 1985, Evolution and present state of the hydrothermal system in Long Valley caldera: Journal of Geophysical Research, v. 90, p. 11,219-11,228.

Sorey, M.L., Lewis, R.E., and Olmsted, F.H., 1978, The hydrothermal system of Long Valley caldera, California: U.S. Geological Survey Professional Paper 1044-A, 60 p.

Sorey, M.L., Suemnicht, G.A., Sturchio, N.C., and Nordquist, G.A., 1991, New evidence on the hydrothermal system in Long Valley caldera, California, from wells, fluid sampling, electrical geophysics, and age determinations of hot-spring deposits: Journal of Volcanology and Geothermal Research, v. 48 , p. $229-263$.
Wahrhaftig, C., 1965, Owens Gorge Overlook, in Wahrhaftig, C., Morrison, R.B., and Birkeland, P.W., eds., Guidebook for Field Conference I, Northern Great Basin and California: INQUA, International Association for Quaternary Research, VIIth Congress, p. 99-101.

Wilson, C.J.N., and Hildreth, W., 1997, The Bishop Tuff: New insights from eruptive stratigraphy: Journal of Geology, v. 105, p. 407-439.

Wilson, C.J.N., and Hildreth, W., 2003, Assembling an ignimbrite: Mechanical and thermal building blocks in the Bishop Tuff, California: Journal of Geology, v. 111, p. 653-670. 

Menlo Park Publishing Service Center, California Manuscript approved August 12, 2016

Edited by Claire Landowski

Design and layout by Vivian Nguyen 
